KAREN MEDEIROS CARDOSO

\title{
DETECÇÃO DE RIQUÉTSIAS DO GRUPO FEBRE MACULOSA EM CÃES E ECTOPARASITAS DE MUNICÍPIOS DO ESTADO DO RIO DE JANEIRO
}

Dissertação apresentada ao Departamento de Parasitologia do Instituto de Ciências Biomédicas da Universidade de São Paulo, para obtenção do Título de Mestre em Ciências. 
KAREN MEDEIROS CARDOSO

\section{DETECÇÃO DE RIQUÉTSIAS DO GRUPO FEBRE MACULOSA EM CÃES E ECTOPARASITAS DE MUNICÍPIOS DO ESTADO DO RIO DE JANEIRO}

Dissertação apresentada ao Departamento de Parasitologia do Instituto de Ciências Biomédicas da Universidade de São Paulo, para obtenção do Título de Mestre em Ciências.

Área de concentração: Biologia da Relação Patógeno-Hospedeiro

Orientadora: Profa. Dra. Teresinha Tizu Sato Schumaker

Versão corrigida. A versão original eletrônica encontra-se disponível tanto na biblioteca do ICB quanto na Biblioteca Digital de Teses e Dissertações da USP (BDTD). 
DADOS DE CATALOGAÇÃO NA PUBLICAÇÃO (CIP)

Serviço de Biblioteca e Informação Biomédica do

Instituto de Ciências Biomédicas da Universidade de São Paulo

reprodução não autorizada pelo autor

Cardoso, Karen Medeiros.

Detecção de Riquétsias do Grupo Febre Maculosa em cães e ectoparasitas de municípios do estado do Rio de Janeiro / Karen Medeiros Cardoso. -- São Paulo, 2013.

Orientador: Profa. Dra. Teresinha Tizu Sato Schumaker.

Dissertação (Mestrado) - Universidade de São Paulo. Instituto de Ciências Biomédicas. Departamento de Parasitologia. Área de concentração: Biologia da Relação Patógeno-Hospedeiro. Linha de pesquisa: Epidemiologia de doenças infecciosas e parasitárias.

Versão do título para o inglês: Detection of Spotted Fever Group Rickettsiae in dogs and ectoparasites of Rio de Janeiro State municipalities.

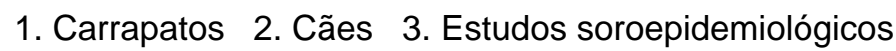
4. Rickettsia sp. I. Schumaker, Profa. Dra. Teresinha Tizu Sato II. Universidade de São Paulo. Instituto de Ciências Biomédicas.

Programa de Pós-Graduação em Biologia da Relação PatógenoHospedeiro III. Título. 
Candidato(a):

Título da

Orientador(a):
Karen Medeiros Cardoso.

Deteç̧ão de Riquétsias do Grupo Febre Maculosa em cães e ectoparasitas de municípios do estado do Rio de Janeiro.

A Comissão Julgadora dos trabalhos de Defesa da Dissertação de Mestrado, em sessão pública realizada a ................., considerou

\section{( ) Aprovado(a)}

( ) Reprovado(a)

Examinador(a): Assinatura:

Nome:

Instituição:

Examinador(a): Assinatura:

Nome:

Instituição:

Presidente:

Assinatura:

Nome:

Instituição: 


\section{Certificado}

Certificamos que o protocolo registrado sob $\mathrm{n}^{\circ} 034$ nas fls. 44 do livro 2 para uso de animais em experimentação, sob a responsabilidade de Teresinha Tizu Sato Schumaker Coordenador(a) da Linha de pesquisa "Pesquisa de agentes infecciosos em potenciais vetores e reservatórios" do qual participou(aram) o(s) alunos Flávia Souza Gherke e os pesquisadores Gilberto Sales Gazeta e Eliana Rodrigues Souza, está de acordo com os Princípios Éticos de Experimentação Animal adotado pelo Colégio Brasileiro de Experimentação Animal (COBEA) e foi aprovado pela COMISSÃO DE ÉTICA EM EXPERIMENTAÇÃO ANIMAL (CEEA) em 27.03.2007.

São Paulo, 28 de março de 2007.

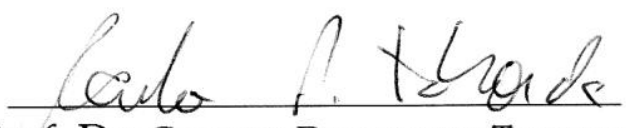

Prof. Dr. CARLOS PELlEschi TABORDA Vice - Coordenador da CEEA - ICB/USP

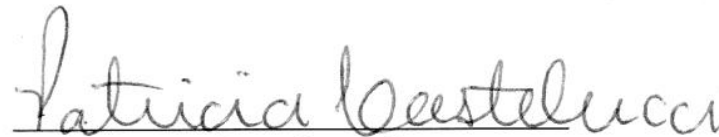

Profa. Dra. PATRÍCIA CASTELUCCI

Secretária da CEEA - ICB/USP 


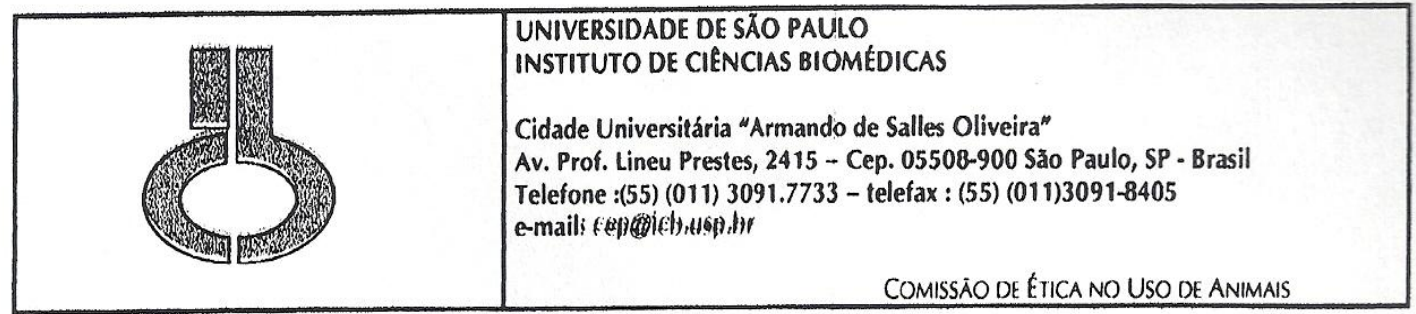

Decl. CEUA.076/2010

\section{DECLARAÇÃO}

Em adendo ao Certificado 034/07/CEEA, datado de 27.03.07 e por solicitação da Profa. Dra. Teresinha Tizu Sato Schumaker, responsável pela linha de Pesquisa, autorizo a inclusão da aluna Karen Medeiros Cardoso ao Projeto de Pesquisa "Pesquisa de agentes infecciosos em potenciais vetores e reservatórios", uma vez que se trata de utilização da mesma espécie animal e de métodos experimentais similares ao referido certificado.

São Paulo, 24 de novembro de 2010.

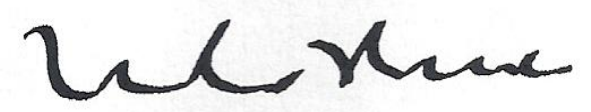

Prof. Dr. Wothan Tavares de Lima

Coordenador da CEEA

ICB/USP 
A Deus, pelo dom da vida, por transformar minhas dores em coragem, por tornar meu horizonte infinito, minha caminhada iluminada, minhas alegrias sólidas, meu coração repleto, meu olhar amoroso. A Ti, toda honra e toda glória! E a minha amada família, por me ensinar a dar valor ao que realmente importa. 


\section{AGRADECIMENTOS}

Ao Conselho Nacional de Desenvolvimento Científico e Tecnológico (CNPq) pela concessão da bolsa. A Fundação de Amparo a Pesquisa do Estado de São Paulo (FAPESP) pelo auxílio financeiro para a realização do trabalho.

A minha orientadora, Professora Doutora Teresinha Tizu Sato Schumaker, por dizer sim à minha orientação, pela competência e inteligência, pela paciência e por saber como ninguém dar leveza a um ambiente, e pelo "sprint final"! Minha estima e admiração.

Ao Professor Dr. Gilberto Salles Gazêta pelo incentivo desde 2008, pelo cuidado, pelos telefonemas, pela amizade e pelas "cartas na manga" quando o trabalho parecia desandar, e pela eterna fé nas pessoas. Obrigada pelo apoio!

A Prof ${ }^{a}$ Dr $^{a}$ Flávia de Sousa Gehrke, pelo apoio à esta pesquisa. Por todos os ensinamentos, conselhos e bancada! Pelo exemplo de mãe que você é. Pelas "terapias" nas horas de aflição, ensinando sobre catarse e amenizando os dias ruins.

A Prof ${ }^{a} \operatorname{Dr}^{\mathrm{a}}$ Andréa Cristina Fogaça pela colaboração na execução do "Real Time", por me acolher tão bem e fazer cada minuto de contato valer à pena, pelo carinho nas horas difíceis, pela preocupação com meu bem estar e pelos conselhos que melhoraram a minha vida. À Mafê, Camila e Larissa pelas ajudinhas, conversas e dicas que quebraram um galhão!

A Fernanda Barbosa (Fer), pela extração dos ectoparasitas desta pesquisa no LIRN, pelo apoio, pelas palavras de encorajamento, pelas orações, pelo sorriso acolhedor.

A doutoranda Nicole Oliveira de Moura, pelo exemplo de fé, determinação, organização, conquista. Pela ajuda nos protocolos, nas dicas de bancada e no inglês. Pela amizade, pelas orações, todos os momentos "série" e brigadeiros de panela, e por me fazer uma madrinha muito feliz!

Ao Departamento de Parasitologia/ICB/USP, ao Programa de Pós Graduação em Biologia da Relação Patógeno-Hospedeiro /ICB/USP e aos docentes que participaram desta caminhada através da transmissão de conhecimento, conselhos e compartilhamento de equipamentos.

Ao Dr. Carlos Augusto Gomes Soares, Dr. Erik Machado Ferreira e ao doutorando Vinícius Vizzoni por me receberem tão bem na UFRJ e pela colaboração.

As minhas queridas vizinhas de laboratório, Priscila (Pri), Melissa (Mel), Vanessa (Van), Natália (Nati), Maria José (Zezé), Michelle, Miluska, Camilla. Por compartilhar os espaços, os conhecimentos, as angústias, as dicas, as histórias de vida de maneira tão 
generosa. Por humanizarem o ambiente e tornarem as tardes de trabalho mais agradáveis. Por tantas ajudas em momentos cruciais e por sempre me receberem com um sorriso. Obrigada!

A Prof ${ }^{\mathrm{a}} \mathrm{Dr}^{\mathrm{a}}$ Marinete Amorim por todo carinho, amizade e apoio, antes, durante e na parte mais difícil desta jornada. Não há palavras para agradecer a quem abriu as portas do seu coração e da sua casa para esta simples estudante. Pela generosidade, muito obrigada!

Ao Prof. Dr. Nicolau Maués Serra-Freire pelo raro exemplo profissional e pessoal, que inspirou e inspira tantos ao mundo científico e acadêmico.

Aos meninos do Sasar pelo apoio e colaboração, e pelo carinho, bom humor e amizade: Patrick, Heitor, Rafael e Nilton. Pela paciência e colaboração: obrigada!

A mestranda Karla Bittencourth (Karlinha), pelo apoio do início ao fim, mesmo de longe, sempre com palavras de encorajamento, amizade. A todos do LIRN pela torcida. Às amigas de uma jornada tão longa, que mostram que a distância é um mero detalhe diante da amizade verdadeira: Juliana Vieira (Ju), Rosiane Mendes (Rosi), Lívia Fraga (Laive). Por todas as experiências vividas, pelo exemplo de força, determinação e pelo carinho. Aos amigos queridos que fiz em SP, Bruno, Chico, Felipe, Ive, Nadia, Jean Pierre, em especial Carlinha, Oneida, Paola, Deise, pelos passeios, almoços, sorrisos, por fazerem do mundo um lugar melhor. Renata (comadre) e Sarinha, que compreendem esta madrinha ausente.

A minha sogrinha, Marisa, "cunha” Aline, Tirene, Gabi, Vovó Yolanda, Tio Cláudio e a toda família Ferreira por ter me "adotado" com tanto carinho e por todas as orações. Obrigada pelo apoio tantas vezes, por me incluírem na lista de presentes e convidados (!), pelas caronas e passeios, pelos esforços em me animar. Vocês são um presente de Deus.

Ao meu noivo, Flávio Granells, meu orgulho, por me ouvir, me ajudar e me incentivar. Por aguentar a distância e a "maratona telefônica", para que eu nunca me sentisse só. Por fazer valer cada dia. Pela certeza que me dá de que tudo vai terminar bem.

A minha mãe, Maria de Fátima, o amor da minha vida, que faz caber tanta fé em um "espaço" tão pequeno! Ao meu pai, Loreni, por todos os dias embaixo do sol, por tentar dar o que não recebeu. Ao meu irmão, por me fazer mais forte pelo exemplo, por me dar suporte sem jamais pedir algo em troca. Você é o verdadeiro sentido do "fraterno". À minha madrinha Mazé, e a todos que, de longe, torceram por mim.

A Deus, por estar comigo todos os dias, dando sentido a caminhada nesta vida. 
O altitudo divitiarum et sapientiae et scientiae Dei! Quam incomprehensibilia sunt iudicia eius, et investigabiles viae eius!

(Epistula ad Romanos 11:33) 


\section{RESUMO}

CARDOSO, K. M. Detecção de riquétsias do Grupo Febre Maculosa em cães e ectoparasitas de municípios do estado do Rio de Janeiro. 2013. 75 f. Dissertação (Mestrado em Biologia da Relação Patógeno-Hospedeiro) - Instituto de Ciências Biomédicas, Universidade de São Paulo, São Paulo, 2013.

Riquetsioses são zoonoses com manifestações epidêmicas, variando segundo características de ecótopo, atividade humana e bio-ecologia de vetores. A maioria dos casos de Febre Maculosa Brasileira (FMB) ocorrem na região sudeste do país. O estado do Rio de Janeiro (RJ) apresenta várias unidades de conservação do bioma Mata Atlântica, propiciando o contato humano com a natureza e favorecendo surtos epidêmicos de zoonoses. Neste estado, vários casos fatais vêm sendo registrados e estudos epidemiológicos em seus diferentes ecótopos se fazem necessários. O objetivo deste projeto foi avaliar o status epidemiológico de riquétsias Grupo Febre Maculosa (GFM) em cães e ectoparasitas de seis municípios do estado do Rio de Janeiro. Para tanto, buscou-se: a) pesquisar anticorpos IgG contra riquétsias GFM em soros caninos utilizando Reação de Imunofluorescência Indireta (RIFI); b) detectar riquétsias nestes soros e em ectoparasitas utilizando PCR e PCR quantitativo, procedendo seu diagnóstico molecular através de análise de sequências nucleotídicas, e, c) analisar a funcionalidade dos iniciadores VNTRB para a região VNTR de Rickettsia rickettsii para detecção e genotipagem de amostras de origem brasileira. Foram coletados soros de 172 cães dos municípios Mangaratiba, Arraial do Cabo, Paraíba do Sul, Japeri, Queimados e Rio de Janeiro, dos quais 117 (68\%) foram positivos na RIFI. Nos soros de quatro animais $(2,32 \%)$ foi detectado gene riquetsial ( $g l t \mathrm{~A})$. Os 358 ectoparasitos (carrapatos e pulgas) coletados no município de Petrópolis, foram organizados em 262 amostras e, em $16(6,10 \%)$ delas houve amplificação do gene investigado. Na análise das sequências, os fragmentos apresentaram entre $99 \%$ e $100 \%$ de identidade com Rickettsia felis ou $R$. rickettsii com sequências disponibilizadas no GenBank. Constatou-se sorologia positiva em cães de todos os municípios investigados. Em Japeri, Arraial do Cabo e Paraíba do Sul constituiu-se a primeira notificação. Demonstrou-se pela primeira vez Rickettsia sp. no soro de cães oriundos de quatro bairros investigados, dos municípios do Rio de Janeiro e Japeri, indicando a importância destes animais na cadeia epidemiológica de riquétsias na região Metropolitana do Rio de Janeiro. Diagnosticou-se Rickettsia felis em Ctenocephalides felis e R. rickettsii em Amblyomma cajennense indicando o envolvimento deste carrapato no surto com casos fatais ocorrido no município de Petrópolis. Pôde-se amplificar a região VNTR pesquisada em diferentes amostras de $R$. rickettsii, o mesmo não se verificando em amostras de $R$. felis, Rickettsia parkeri, Rickettsia rhipicephali ou Rickettsia bellii, sugerindo espécieespecificidade dos iniciadores utilizados. O estudo aponta também a limitação do uso dos iniciadores (VNTRB) para a região VNTR na diferenciação genotípica das cepas de $R$. rickettsii analisadas. Os resultados confirmam a presença de riquétsias patogênicas em área de Floresta Tropical, indicando a importância de um sistema de vigilância de ambiente que detecte vetores e efetue medidas de controle, prevenindo os casos fatais nesta área de turismo ecológico internacional.

Palavras-chave: Febre Maculosa. Rickettsia rickettsii. Cães. Carrapatos. VNTR. 


\begin{abstract}
CARDOSO, K. M. Detection of Spotted Fever Group Rickettsiae in dogs and ectoparasites of Rio de Janeiro State municipalities. 2013. 75 p. Masters thesis (Biology of Host-Pathogen Interactions) - Instituto de Ciências Biomédicas, Universidade de São Paulo, São Paulo, 2013.

Rickettsial diseases are zoonoses with epidemic manifestations, that vary according to characteristics of breeding sites, human activity and bio-ecology of vectors. Most cases of Brazilian Spotted Fever (BSF) occur in the southeastern region of the country. The state of Rio de Janeiro (RJ) has several protected areas of the Mata Atlantica biome, providing human contact with nature and increasing the risks of zoonoses outbreaks. In this state, several fatal cases have been reported and epidemiological studies in their different ecotopes are needed. The objective of this project was to evaluate the epidemiological status of Rickettsia Spotted Fever Group (RSFG) in dogs and ectoparasites from six municipalities in the state of Rio de Janeiro. For that it was done: a) research of rickettsiae SFG IgG antibodies in dog serum using Indirect Immunofluorescence Assay (IFA), b) detection of rickettsiae in these sera and in ectoparasites using PCR and quantitative PCR, and its molecular diagnostic through nucleotide sequences analysis, and c) functionality analisis of the VNTRB initiators for the VNTR region of Rickettsia rickettsii for detection and genotyping Brazilian origin samples. It was collected sera from 172 dogs from Mangaratiba, Arraial do Cabo, Paraíba do Sul, Japeri, Queimados, and Rio de Janeiro municipalities, of which 117 (68\%) were positive by IFA. In the sera of four animals $(2.32 \%)$ it was detected riquetsial gene $(\mathrm{glt}$ A). The 358 ectoparasites (ticks and fleas) collected in Petrópolis, were organized in 262 samples, and in $16(6.10 \%)$ of them there was amplification of the investigated gene. Sequence analysis showed fragments presenting between $99 \%$ and $100 \%$ identity with Rickettsia felis or R. rickettsii with GenBank available sequences. Positive serology was found in dogs of all municipalities surveyed, being the first notification of this infection in Japeri, Arraial do Cabo, and Paraíba do Sul. It was demonstrated for the first time Rickettsia $s p$. in serum from dogs of four districts surveyed, from the municipalities of Rio de Janeiro and Japeri, indicating the importance of these animals in the epidemiological chain of rickettsiae in the metropolitan region of Rio de Janeiro. Rickettsia felis was diagnosed in Ctenocephalides felis felis and R. rickettsii in Amblyomma cajennense indicating the involvement of this tick in the outbreak with fatal cases occurred in Petrópolis. It was possible to amplify the VNTR region investigated in different samples of $R$. rickettsii, the same was not possible with samples of $R$. felis, Rickettsia parkeri, Rickettsia rhipicephali or Rickettsia. bellii, suggesting primers speciesspecificity. The study also points out the limitation of the use of VNTRB primers for the VNTR region in genotypic differentiation of the $R$. rickettsii strains analyzed. The results confirm the presence of pathogenic rickettsia in Tropical Forest area, indicating the importance of a surveillance system that detects vectors to perform control measures and prevent fatal cases in this area of international ecological tourism.
\end{abstract}

Keywords: Spotted fever. Rickettsia rickettsii. Dogs. Ticks. VNTR. 


\section{LISTA DE ILUSTRAÇÕES}

Figura 1 - Mapa do Estado do Rio de Janeiro com municípios de coleta de soros e/ou artrópodes

Figura 2 - Mapa do município de Petrópolis com locais de coleta de artrópodes.

Figura 3 - Curvas de diluição seriada (curva padrão) para PCR em Tempo Real.......... 36

Figura 4 - Curvas de amplificação de amostras de ectoparasitas do município de Petrópolis, Estado de Rio de Janeiro.

Figura 5 - Filodendograma obtido através da comparação das sequências parciais do gene gltA (CS2 - 401pb), utilizando o método Neighbor-

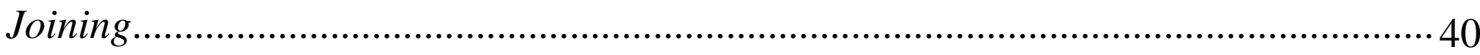

Figura 6 - Filodendograma obtido através da comparação das sequências parciais do gene gltA (CS4 - 834pb), utilizando o método Neighbor-Joining

Figura 7 - Gradiente de temperatura para os oligonucleotídeos VNTRB em gel de agarose.

Figura 8 - Gel de agarose da PCR para fragmento intergênico (VNTRB - 214pb) evidenciando degradação do DNA genômico das amostras.

Figura 9 - Gel de agarose da PCR para fragmento intergênico (VNTRB - 214pb)...... 44

Figura 10 - Gel de agarose da PCR para fragmento intergênico (VNTRB - 214pb) mostrando a ausência de amplificação.

Figura 11 - Alinhamento das sequências obtidas da região intergênica com sequências depositadas no GenBank, com destaque para as repetições sequenciais. 


\section{LISTA DE TABELAS}

Tabela 1 - Oligonucleotídeos utilizados nos ensaios moleculares

Tabela 2 - Prevalência de amostras de soro canino positivas para a presença de anticorpos anti-Rickettsia sp. e titulação obtida por localidadade segundo Reação de Imunofluorescência Indireta (RIFI), em municípios do Estado do Rio de Janeiro, Brasil

Tabela 3 - Prevalência de amostras de soro canino positivas para a presença de anticorpos anti-Rickettsia sp. e frequência de títulos no estudo, detectados pela Reação de Imunofluorescência Indireta (RIFI), em municípios do Estado do Rio de Janeiro, Brasil.

Tabela 4 - Amostras de soro caninos com amplificação de gene rickettsial ( $g l t \mathrm{~A})$ procedentes do Estado do Rio de Janeiro.

Tabela 5 - Frequência absoluta e relativa de potenciais vetores coletados, segundo hospedeiro presente nos municípios investigados para Febre Maculosa Brasileira, no estado do Rio de Janeiro

Tabela 6 - Frequência absoluta de potenciais vetores coletados no município de Petrópolis investigados para Febre Maculosa Brasileira, no estado do Rio de Janeiro

Tabela 7 - Pesquisa de gene riquetsial em amostras de potenciais vetores, por PCR em Tempo Real, segundo hospedeiro, investigados para Febre Maculosa Brasileira, no município de Petrópolis, região Serrana do Estado do Rio de Janeiro.

Tabela 8 - Identificação de riquétsia em ectoparasitas procedentes do município de Petrópolis, região Serrana do Estado do Rio de Janeiro.

Tabela 9 - Amostras de vetores utilizadas na pesquisa da região intergênica repetitiva 


\section{LISTA DE ABREVIATURAS E SIGLAS}

${ }^{\circ} \mathrm{C}$ - Graus Celsius

$\mu \mathrm{g}$ - Micrograma

$\mu \mathrm{L}-$ Microlitro

$\mu \mathrm{M}-$ Micromolar

$10 \mathrm{X}-10$ vezes concentrado(a)

DNA - Desoxyribonucleic Acid - Ácido Desoxirribonucléico

dNTP - Deoxynucleotides triphosphates - Desoxirribonucleotídieos trifosfatados

$\mathrm{g}$ - Aceleração de gravidade $\left(9,8 \mathrm{~m} / \mathrm{s}^{2}\right)$

$\mathrm{h}-$ Hora

$\mathrm{HCl}$ - Ácido Clorídrico

mg - Miligrama

$\mathrm{MgCl}_{2}-$ Cloreto de Magnésio

min - Minuto

ml - Mililitro

$\mathrm{mM}$ - Milimolar

$\mathrm{N}_{2}$ - Nitrogênio

$\mathrm{NaCl}$ - Cloreto de Sódio

$\mathrm{pb}$ - Pares de base

$\mathrm{pH}$ - Potencial hidrogeniônico

qsp - Quantidade suficiente para

SDS - Sodium Dodecyl Sulfate - Dodecil Sulfato de Sódio

TE - Tris-EDTA

Tris - Tris (hidroxi) metil amino metano

$\mathrm{U}$ - Unidade 


\section{SUMÁRIO}

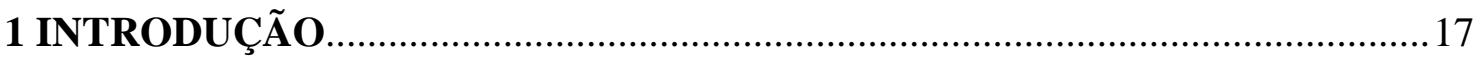

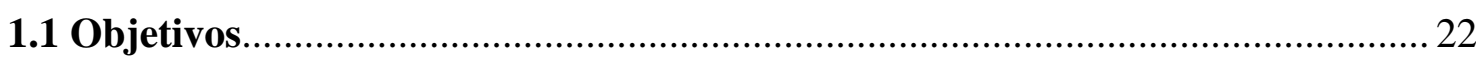

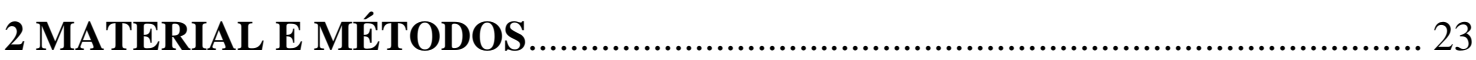

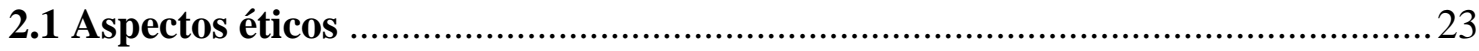

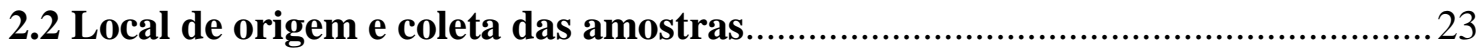

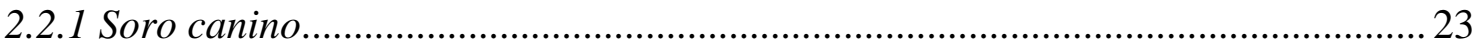

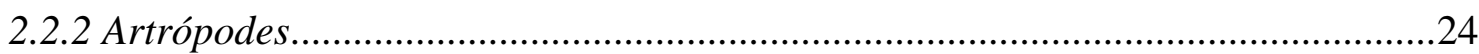

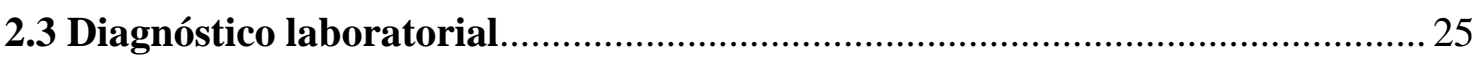

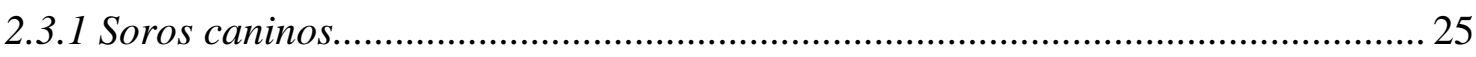

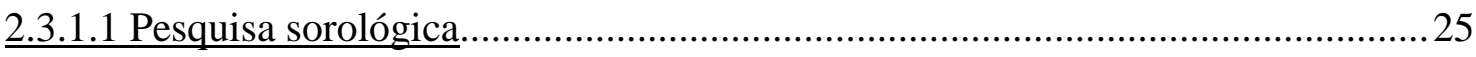

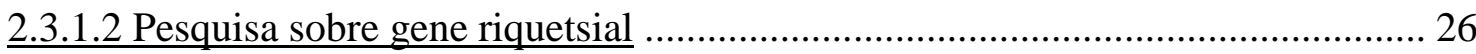

2.3.1.2.1 Extração do DNA genômico............................................................................26

2.3.1.2.2 Reação em Cadeia pela Polimerase................................................................ 26

2.3.1.2.3 PCR em Tempo Real................................................................................... 27

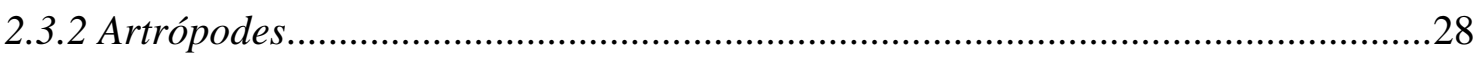

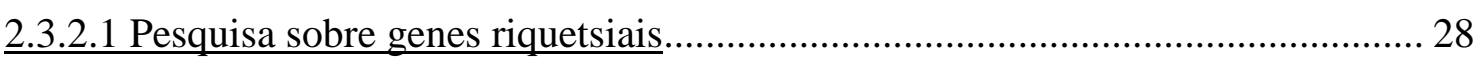

2.3.2.1.1 Extração do DNA genômico...........................................................................2 28

2.3.2.1.2 Amplificação genômica............................................................................... 28

2.3.2.1.3 PCR para deteç̧ão de genes riquetsiais ..........................................................2 29

2.3.2.1.4 Clonagem e Análise de sequências..................................................................29

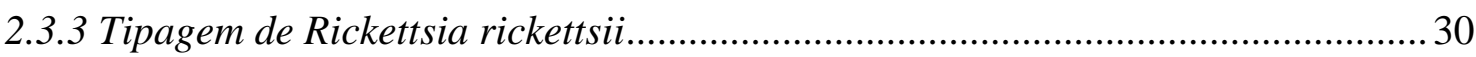

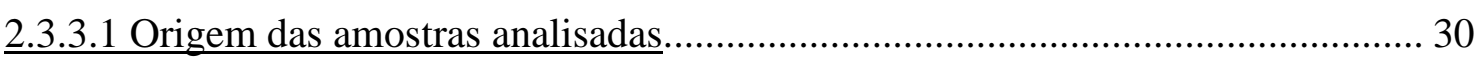

2.3.3.2 PCR para pesquisa de fragmento repetitivo (VNTR) na região intergênica B... 31

2.3.3.3 Sequenciamento e Análise de sequências …………………………………........ 31

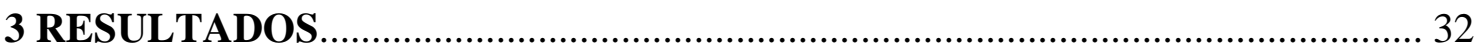

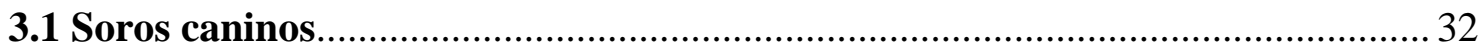

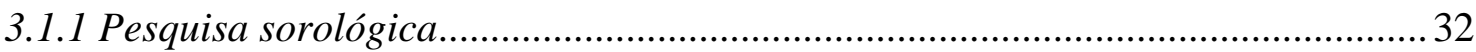

3.1.2 Detecção de gene riquetsial PCR e PCR em Tempo Real......................................33

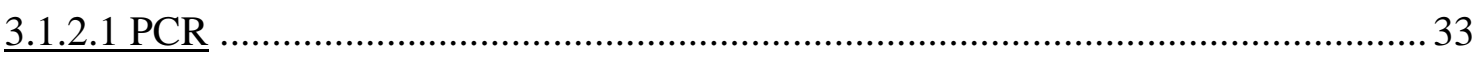

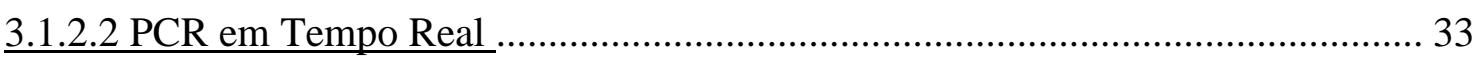

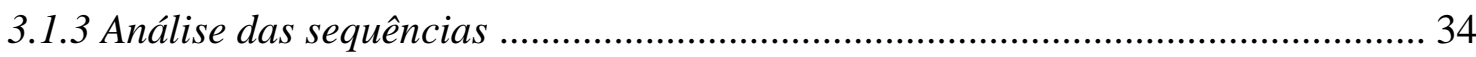

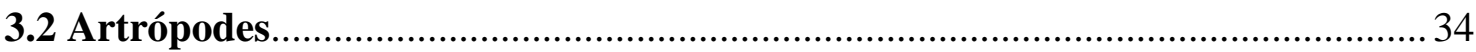




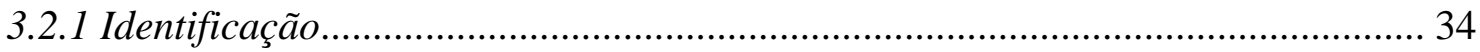

3.2.2 Detecção de gene riquetsial - PCR e PCR em Tempo Real................................. 35

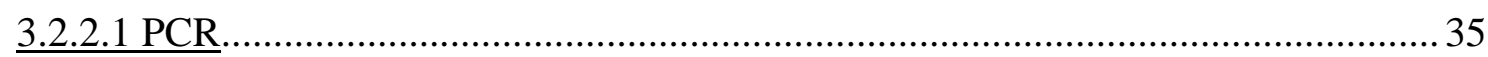

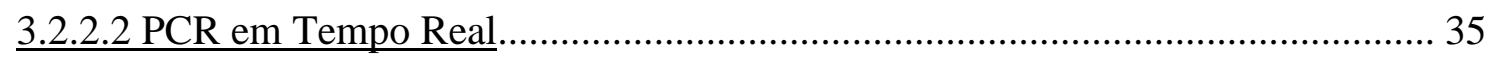

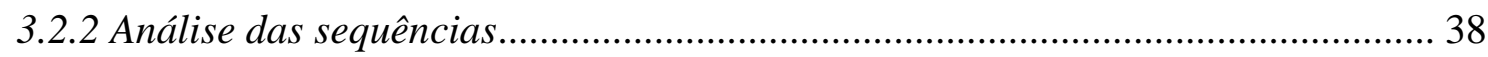

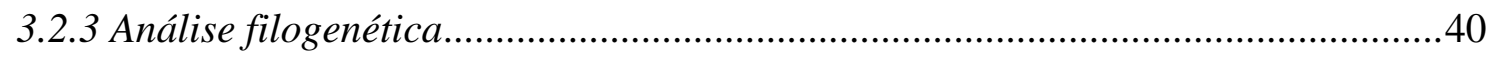

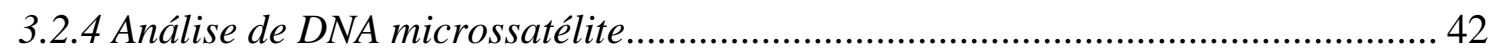

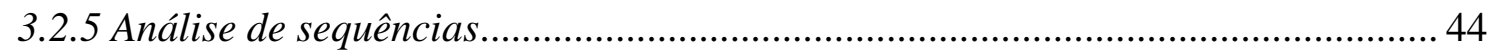

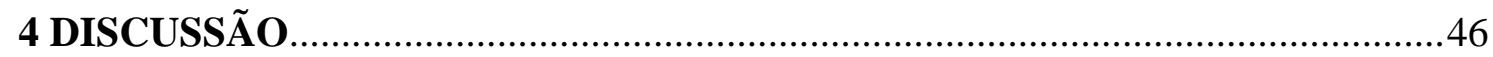

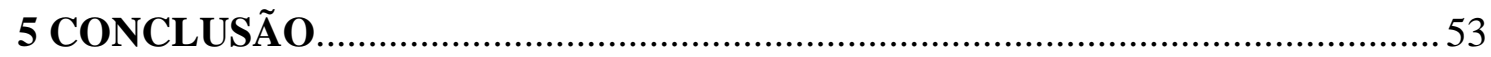

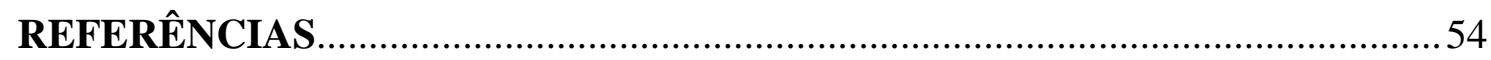

APÊNDICE A - Amostras de ectoparasitas coletados no munícipio de Petrópolis / Rio de Janeiro. 63

APÊNDICE B - Alinhamento de sequências de Rickettsia rickettsii e iniciador VNTRB 


\section{INTRODUÇÃO}

O gênero Rickettsia é composto por pequenas bactérias intracelulares obrigatórias (FOURNIER; RAOULT, 2007), gram negativas, pleomórficas, podendo localizar-se no citoplasma e/ou núcleo da célula hospedeira, dependendo da espécie em questão (EREMEEVA; DASCH, 2000). Tais bactérias pertencem à ordem Rickettsiales, família Rickettsiaceae, cuja taxonomia, na última década, está em constante reorganização, devido aos avanços das técnicas utilizadas para seu estudo e pela elucidação do ciclo enzoótico de alguns de seus membros (PAROLA; DAVOUST; RAOULT, 2005).

As riquetsioses, causadas por organismos do gênero Rickettsia, estão presentes em todos os continentes em focos endêmicos, podendo emergir em intervalos esporádicos de forma epidêmica na população humana (AZAD; BEARD, 1998). Em 1907, Dr. Howard Taylor Ricketts isolou o agente etiológico de uma riquetsiose, a Febre Maculosa das Montanhas Rochosas (FMMR), a partir de carrapatos, estabelecendo então o papel destes na transmissão da doença (RICKETTS, 1909). Hoje, além dos hospedeiros vertebrados, sabe-se que estão presentes no ciclo enzoótico do gênero Rickettsia vários artrópodes que podem atuar tanto como vetores quanto como reservatórios (PAROLA; RAOULT, 2001; SIMSER et al., 2001).

Os organismos do gênero Rickettsia estão divididos, com base em critérios fenotípicos e genotípicos, nos grupos: Ancestral (GA), Tifo (GT) e Febre Maculosa (GFM). O GA inclui Rickettsia bellii e Rickettsia canadensis consideradas de patogenicidade desconhecida. O GT tem sua importância relacionada ao tifo epidêmico (causado pela Rickettsia prowazekii, vetorada ao homem por piolho) e o tifo murino (causado pela Rickettsia typhi, transmitida por pulgas) (RAOULT; ROUX, 1997; ROUX et al., 1997; ROUX; RAOULT; 2000; STOTHARD; CLARK; FUERST, 1994).

Atualmente, mais de 30 espécies de Rickettsia são reconhecidas dentro do GFM, tendo sido encontradas ao redor do mundo. Destas, ao menos 16 são consideradas como patogênicas: Rickettsia aeschlimannii, Rickettsia africae (Febre Africana da Picada do Carrapato), Rickettsia akari (Riquetsiose Variceliforme), Rickettsia australis (Febre de Queensland), Rickettsia conorii, (Febre Maculosa Mediterrânea ou Febre Botonosa), Rickettsia felis (Riquetsiose Felis), Rickettsia heilongjiangensis (Febre Maculosa do Extremo Oriente), Rickettsia helvetica, Rickettsia honei (Riquetsiose da Ilha de Flinders), Rickettsia japonica (Febre Maculosa Oriental), Rickettsia marmioni, Rickettsia massilae, Rickettsia parkeri, (Febre Maculosa Ganglionar) (PADDOCK et al., 2004), Rickettsia rickettsii (Febre 
Maculosa das Montanhas Rochosas), Rickettsia sibirica (Riquetsiose do Norte da Ásia ou Tifo siberiano) e Rickettsia slovaca (Linfoadenopatia do carrapato ou TIBOLA). As espécies R. akari e R. felis são transmitidas, respectivamente, por pequenos ácaros e pulgas. As demais são vetoradas por carrapatos (PAROLA; DAVOUST; RAOULT, 2005). Nas riquetsioses GFM, os sintomas mais frequentes são: cefaléia, febre aguda e mal estar generalizado. Manifestações cutâneas podem ou não ocorrer. Este quadro é comum à várias outras doenças como dengue, gripe, hepatite viral, leptospirose, salmonelose e malária sendo recomendado o diagnóstico diferencial (BRASIL, 2010).

Enquanto isoladas apenas de artrópodes, as riquétsias são consideradas não patogênicas para o ser humano. Ao serem detectadas causando doença, são incluídas no GFM de riquétsias patogênicas, como ocorreu com $R$. parkeri, só recentemente responsabilizada pela febre maculosa ganglionar (PADDOCK et al., 2004). Alguns autores acreditam que todas as espécies de riquétsia podem ter potencial patogênico, desde que o artrópode reservatório seja capaz de picar humanos (SCOLA; RAOULT, 1997). No caso do carrapato, uma vez infectado, pode carrear o patógeno durante toda vida e manter a circulação do mesmo na natureza através de transmissão transovariana e transestadial (CENTERS FOR DISEASE CONTROL AND PREVENTION, 2006). Desta forma, os carrapatos constituem-se como vetores e também reservatórios naturais do agente, mantendo e transmitindo a bactéria para os vertebrados (PAROLA; RAOULT, 2001; SIMSER et al., 2001).

Em determinadas áreas podem coexistir vetores e reservatórios de riquétsias GFM, patogênicas ou de patogenicidade desconhecida, o que torna muito importante mapear a presença de riquétsias de interesse para saúde pública, tanto em artrópodes quanto em hospedeiros vertebrados (CHEN et al., 1998).

No Brasil, a enfermidade causada pela $R$. rickettsii, transmitida por carrapatos do gênero Amblyomma, é conhecida desde o século XX, como Febre Maculosa Brasileira, sendo similiar à Febre Maculosa das Montanhas Rochosas dos Estados Unidos (DIAS; MARTINS, 1939). As manifestações cutâneas frequentemente observadas na infecção, estão associadas à vasculite causada pela multiplicação do agente no tecido endotelial. Pode ser fatal se não diagnosticada precocemente e tratada adequadamente. A riquetsiose felis, pouco frequente nas diferentes partes do mundo onde foi descrita, é causada por $R$. felis e transmitida por pulga, também está relatada no país (BROUQUI et al., 2004; PAROLA; DAVOUST; RAOULT, 2005; RAOULT; ROUX, 1997). Nos últimos 10 anos, casos mais brandos de Febre Maculosa associados com uma maior frequência de adenomegalia e ausência de óbito têm sido identificados em Santa Catarina e também nos estados do Paraná e Rio Grande do Sul 
(LEMOS, 2012). Recentemente, um estudo identificou indícios de uma nova riquetsiose do GFM causada por uma nova riquétsia, relacionada à Rickettsia parkerii, $R$. africae e $R$. sibirica, em São Paulo (SPOLIDORIO, 2010).

Em diferentes estados do Brasil, animais domésticos e silvestres (cães, equinos, capivaras, roedores e morcegos, entre outros), procedentes de áreas endêmicas de FMB, apresentam sorologia positiva para riquétsias (DIAS; MARTINS, 1939; MORAES-FILHO et al., 2009a; PACHECO et al., 2007; PINTER et al., 2008; SPOLIDORIO et al., 2010; VIANNA et al., 2008). Com base em inquéritos soro-epidemiológicos, admite-se que estes animais possam constituir sentinelas para FMB. Genes riquetsiais ( $g l t A$ e ompA) foram detectados em soro de cães e equinos infectados, salientando a importância destes animais com relação ao ciclo peridomiciliar da doença (GEHRKE, 2010).

Nas últimas décadas, a Febre Maculosa foi relatada em todos estados da região Sudeste do Brasil (GALVÃO et al., 2005; LEMOS; ROZENTAL; VILLELA, 2002; MELLES; COLOMBO; LEMOS, 1999; SEXTON et al., 1993), utilizando métodos imunológicos. No entanto, a confirmação molecular das espécies de riquétsias infectando humanos foi realizada apenas recentemente. Dois pacientes com quadro clínico compatível com FMB foram a óbito e posteriormente diagnosticou-se, por métodos sorológicos e moleculares, R. felis presente no organismo do paciente (GALVÃO et al., 2004). Esta riquétsia está registrada em pulgas de vários estados (HORTA et al., 2006; OLIVEIRA et al., 2008). Já $R$. rickettsii foi identificada em dois pacientes humanos do Rio de Janeiro (LAMAS et al., 2008; ROZENTAL et al., 2006) e em cerca de 20 outros no estado de São Paulo (GEHRKE, 2010; NASCIMENTO, 2003). O advento das técnicas moleculares permitiu um significativo avanço na descoberta de novas riquétsias e riquetsioses, assim como para o entendimento sobre relações artrópode-patógeno. Mais recentemente, ferramentas moleculares têm sido utilizadas para caracterização de cepas detectadas em humanos, animais e potenciais vetores, visando o esclarecimento sobre a circulação de uma riquétsia entre os elementos da cadeia epidemiológica.

Em vários estados do Brasil, riquétsias do GFM têm sido diagnosticadas em várias espécies de carrapatos com base na análise de genes riquetsiais (HORTA et al., 2006; LABRUNA et al., 2004a; OLIVEIRA et al., 2008). Em Amblyomma cajennense (carrapato primário de cavalos), considerado o principal vetor de FMB, o diagnóstico molecular específico de $R$. rickettsii foi possível somente em alguns exemplares coletados em Minas Gerais (CARDOSO et al., 2006; GUEDES et al., 2005) e, mais recentemente, nos estados de São Paulo e Rio de Janeiro (GEHRKE, 2010; MOURA, 2012). Também pôde ser 
diagnosticada em alguns exemplares de Amblyomma aureolatum (carrapato primário de cães) coletados em Mogi das Cruzes (PINTER; LABRUNA, 2006). A prevalência da riquetsiose entre humanos no Estado do Rio de Janeiro é inferior àquela verificada no estado de São Paulo. Entretanto, neste último estado, a despeito dos numerosos estudos realizados, a riquétsia foi diagnosticada em apenas alguns exemplares de carrapatos. As diferenças epidemiológicas verificadas sugerem a possibilidade de ocorrência de diferentes cepas de $R$. rickettsii circulando entre potenciais vetores e reservatórios nas diferentes regiões fisiogeográficas do país.

No estado do Rio de Janeiro, tem sido realizados estudos soroepidemiológicos de animais domésticos associados à epidemiologia molecular em alguns municípios. Rickettsia rickettsii foi identificada em humanos, várias espécies de carrapatos, pulgas e em alguns cães e equinos de alguns municípios (GEHRKE, 2010; LAMAS et al., 2008; MOURA, 2012; ROZENTAL et al., 2006). A frequência de artrópodes infectados pela riquétsia foi superior àquelas observadas em outros estados. $R$. felis, causadora da riquetsiose felis, também foi diagnosticada nos artrópodes. Além do Amblyomma cajennese, considerado principal carrapato transmissor da FMB, pôde-se observar, pela primeira vez, várias espécies de carrapatos parasitas específicos de bovinos, equinos e cães, e usualmente não antropofílicos, carreando $R$. rickettsii (GEHRKE, 2010). Em uma das regiões estudadas, com o grande número de óbitos associados a FM, após ensaio de imunofluorescência indireta (RIFI), um espécime de Rhipicephalus sanguineus, carrapato adaptado a condições urbanas, foi constatado albergando riquétsia GFM (ROZENTAL et al., 2002). Posteriormente, estudos moleculares (CUNHA et al., 2009; GEHRKE et al., 2009; MOURA, 2012) diagnosticaram $R$. rickettsii em carrapatos desta espécie, sugerindo uma considerável chance de participação ativa desta espécie no ciclo da riquetsiose em áreas peridomicílio e domicílios carreada pelos cães. Nos EUA já foi confirmado como vetor de Febre Maculosa das Montanhas Rochosas (DEMMA et al., 2005). Os cães destacam-se como fonte de infecção para os carrapatos e têm sido considerados como amplificadores e sentinelas de riquétsia (LABRUNA, 2006; SANGIONI, 2003), assumindo papel importante para o estabelecimento de prevalências geográficas de FM em uma região.

No Rio de Janeiro, a FMB é descrita desde a década de 40, sem, no entanto, confirmação vetorial da maioria dos casos. Os estudos moleculares recentes têm contribuído para estabelecer o status do gênero Rickettsia na região. No Rio de Janeiro, durante os anos de 2007 a 2012, foram registrados no SINAN (Sistema Nacional de Agravos de Notificação) o total de 135 casos humanos suspeitos de FMB, dos quais 54 foram confirmados (BRASIL, 
2012). Dados dos registros oficiais da Secretaria Estadual de Saúde do estado do Rio de Janeiro descrevem a maior parte dos registros ocorridos na região metropolitana do Rio. Quanto ao desenvolvimento dos casos no Estado do Rio de Janeiro, 25 evoluíram para óbito, o que representa $46,3 \%$ do total de casos confirmados. Em áreas de foco ativo deste estado, em estudos sobre potenciais vetores de FM utilizando técnicas moleculares, foi diagnosticado $R$. rickettsii em Boophilus microplus, Ctenocephalides felis, Anocentor nitens, A. cajennense, A. aureolatum (GEHRKE, 2010), em C.canis (MOURA, 2012) e em R. sanguineus em municípios do interior do estado (CUNHA et al., 2009; GEHRKE et al., 2009). O diagnóstico de $R$. rickettsii em algumas espécies de artrópodes constituem confirmações inéditas, carecendo maiores estudos para esclarecimento sobre o valor epidemiológico dos encontros registrados.

Atualmente o diagnóstico laboratorial das doenças riquetsiais é baseado nas técnicas de isolamento, detecção imunológica e análise genética (ORGANIZAÇÃO PANAMERICANA DA SAÚDE, 2004). O ensaio por RIFI é a metodologia preconizada pela Organização Mundial da Saúde para o diagnóstico de Rickettsia. Recomenda-se, quando possível, o isolamento em cultura de células e/ou imuno-histoquímica, possibilitando o diagnóstico das riquétsias no nível de GFM (PADDOCK et al., 1999). A análise genética para o diagnóstico específico baseia-se na amplificação de fragmentos de genes do DNA de Rickettsia, extraído de material biológico de vertebrado e artrópode vetor, pelo uso da Reação em Cadeia da Polimerase (PCR) e comparação da sequência de fragmentos de genes amplificados. Fournier e Raoult (2009) afirmam que a comparação das organizações filogenéticas obtidas a partir do estudo de vários genes (principalmente gltA, ompA e ompB) fornece bases para que seja estabelecida uma taxonomia confiável das bactérias incluídas no gênero Rickettsia.

Recentes estudos moleculares dos agentes riquetsiais tem se voltado para uso de sequências intergênicas de genes comumente amplificados por PCR no diagnóstico desses agentes. Tais estudos baseiam-se, entre outros aspectos, na análise de fragmentos de alta repetição do gene, além de variações que indicam inserções ou deleções num determinado locus, podendo caracterizar novas cepas de uma mesma espécie.

O Número Variável de Repetições Sequenciais (VNTR) consiste em repetições numéricas que podem frequentemente variar quanto ao número de cópias. Desta maneira, mostram polimorfismos de comprimento entre os indivíduos. A amplificação é obtida a partir de regiões flanqueadoras bem conservadas (VITORINO, 2005). 
Em 2004, Fournier e colaboradores, com o objetivo de desenvolver uma ferramenta de genotipagem para determinar possíveis cepas de $R$. conorii, encontraram repetições altamente conservadas nos espaços intergênicos pesquisados. Tais repetições estavam presentes apenas no locus estudado. Os autores reiteram que a variabilidade interindividual de comprimento num locus único é designada por VNTRs. O trabalho demonstrou que os espaços intergênicos variáveis são os mais adequados para estudos de genotipagem.

Eremeeva e colaboradores (2006) e Wikswo e colaboradores (2007), analisaram a sequência de nucleotídeos em repetição, do genoma de riquétsias extraído de amostras de carrapatos e humanos de diferentes regiões dos EUA (Arizona, Califórnia). As regiões de VNTR foram selecionadas por tamanho e localização, e comparadas com uma sequência previamente conhecida, $R$. rickettsii cepa Bitterroot, originária de Montana. Diferentes cepas de $R$. rickettsii puderam ser caracterizadas entre as espécies de carrapatos analisadas, relacionadas à distribuição geográfica e infecção humana. A caracterização de cepas poderá possibilitar estudos epidemiológicos que monitorem a mudança das populações microbianas no decorrer do tempo (FOURNIER et al., 2004). Segundo Eremeeva e Dasch (2009), a virulência de uma cepa para os hospedeiros vertebrados pode estar relacionada com a variabilidade genéticos, sendo identificada através de marcadores genéticos, tal qual mostraram estes estudos prévios. No Brasil, nenhum estudo foi desenvolvido utilizando marcadores de microssatélite para $R$. rickettsii.

\subsection{Objetivos}

O objetivo geral deste projeto foi avaliar o status epidemiológico de riquétsias do GFM em cães e ectoparasitas de municípios do estado do Rio de Janeiro, com base em métodos sorológicos e/ou moleculares. Para alcançá-lo, buscamos especificamente:

a) pesquisar a presença de anticorpos contra estes organismos em cães;

b) investigar a presença de genes riquetsiais nas amostras de soro de cães e em ectoparasitas procedendo seu diagnóstico molecular específico e;

c) Analisar a funcionalidade dos iniciadores VNTRB para a região VNTR (Número Variável de Repetições Sequenciais) de R. rickettsii para detecção e genotipagem de amostras de origem brasileira. 


\section{MATERIAL E MÉTODOS}

\subsection{Aspectos éticos}

Os protocolos de pesquisa e procedimentos adotados para esta dissertação foram analisados e aprovados pela Comissão de Ética para Experimentação Animal do Instituto de Ciências Biomédicas/USP (034, fls 44, livro 2).

\subsection{Local de origem e coleta das amostras}

\subsubsection{Soro canino}

O material é procedente de coleta sanguínea de 172 cães de seis municípios do estado do Rio de Janeiro: Região Metropolitana: Japeri (22³8'35" S; 43³9'12" W),

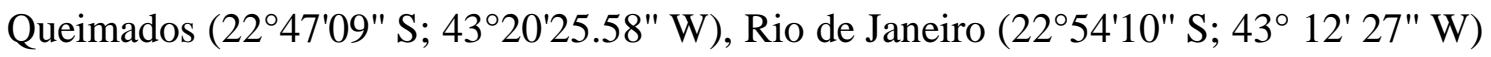

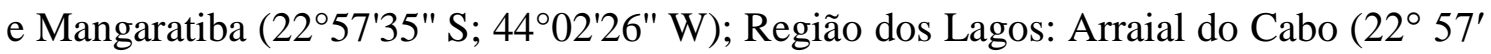
58" S, $42^{\circ} 1^{\prime}$ 44" W); Região Centro-Sul: Paraíba do Sul (2209'43" S; 43¹7'34" W), durante o ano de 2008 (Figura 1). A coleta foi realizada com apoio de uma equipe da Secretaria Municipal de Saúde, e as amostras encaminhadas ao Laboratório de Referência Nacional em Vetores das Riquetsioses (LIRN) IOC - FIOCRUZ. Os cães foram submetidos à venopunção radial para a coleta de 5 a 10 mililitros de sangue. As amostras permaneceram resfriadas em temperatura entre $4{ }^{\circ} \mathrm{C}$ e $8{ }^{\circ} \mathrm{C}$ até a retração do coágulo e obtenção do soro sanguíneo e, em seguida, aliquotados em microtubos estéreis previamente identificados com o número de entrada da amostra no laboratório. O material obtido foi acondicionado a $-20^{\circ} \mathrm{C}$ até seu processamento, realizado no LIRN. 
Figura 1 - Mapa do Estado do Rio de Janeiro com municípios de coleta de soros e/ou artrópodes

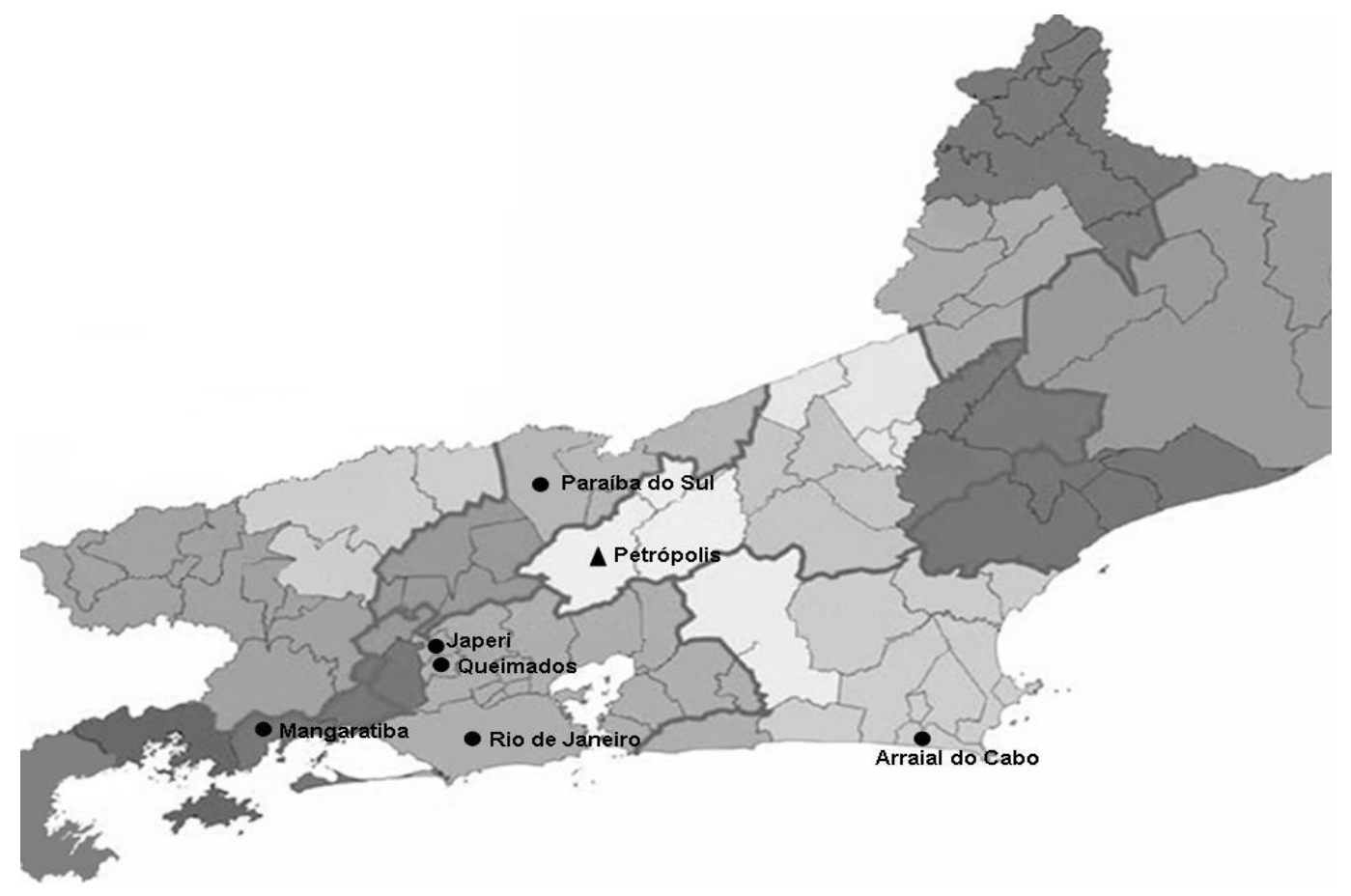

-: Coleta de soro; $\boldsymbol{\Lambda}$ : Coleta de artrópodes

Fonte: Modificado de Moura (2012).

\subsubsection{Artrópodes}

Os ectoparasitos foram coletados em área focal de Febre Maculosa no município turístico de Petrópolis, Região Serrana do Estado do Rio de Janeiro. Nesta região foram descritos casos humanos nos últimos anos. As coletas foram realizadas em quatro

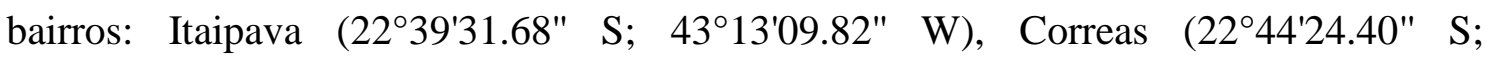

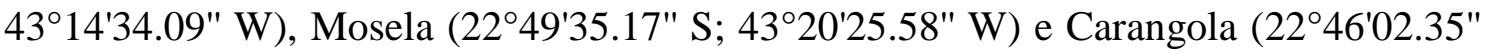
S; 4316'26.06" W), em diferentes pontos de coleta (Figura 2).

As coletas foram realizadas no ano de 2005, ocasião de surto epidêmico, pelas Secretarias Municipal e Estadual de Saúde em parceria com a equipe do LIRN (exceto a amostra 273-4, coletada em 2010). Os ectoparasitas foram coletados sobre caninos, felinos, bovinos, equinos e humanos presentes na localidade de provável infecção humana, bem como no ambiente.

Quando no hospedeiro, os ixodídeos (carrapatos) foram coletados através do método de torção sobre o próprio eixo longitudinal do idiossoma, e no ambiente a coleta foi realizada seguindo a técnica de arrasto de flanela branca (OLIVEIRA, 1998) e busca 
ativa. Os sifonápteros (pulgas) foram coletados por captura no hospedeiro. Foram acondicionados em microtubos estéreis contendo isopropanol absoluto e encaminhados para o LIRN.

Figura 2 - Mapa do município de Petrópolis com locais de coleta de artrópodes

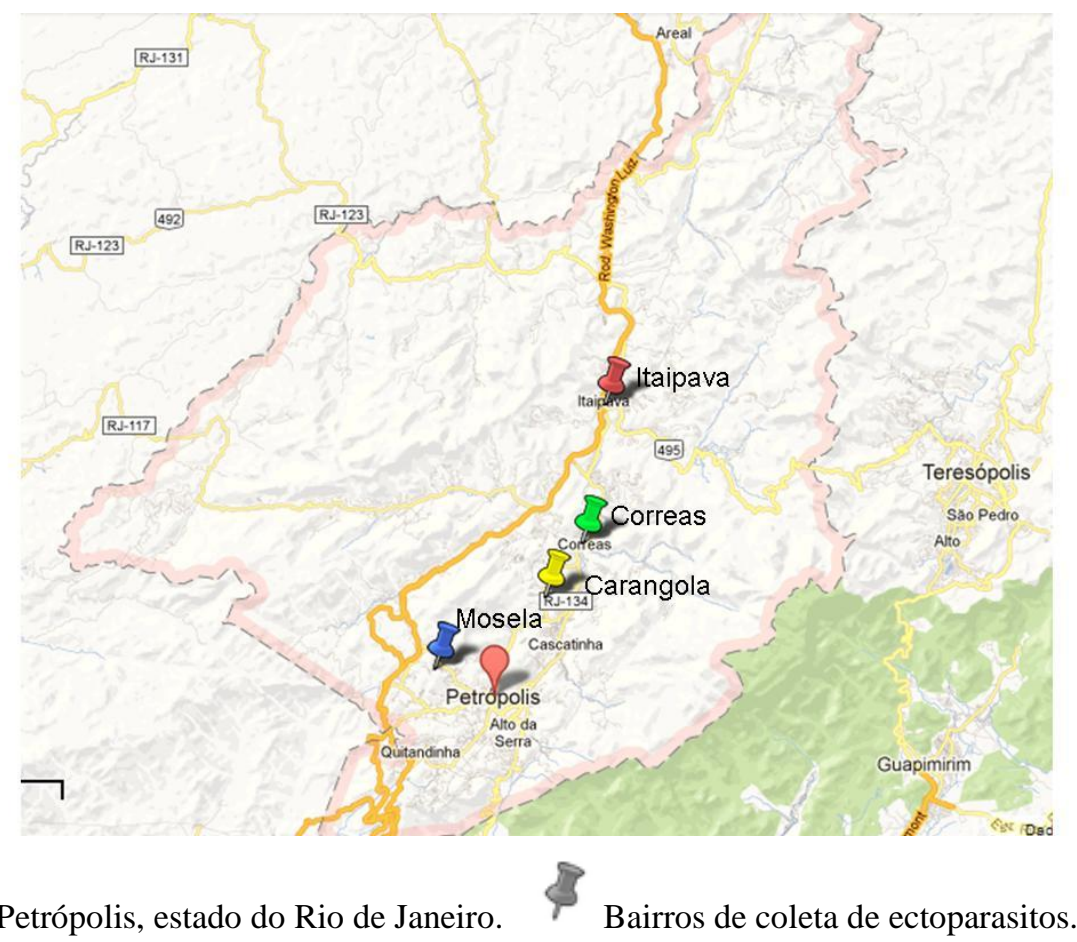

Município de Petrópolis, estado do Rio de Janeiro. Fonte: Google Maps (2013).

A identificação seguiu o Procedimento Operacional Padrão para Identificação Taxonômica de Vetores das Riquétsias (POP-LIRN-017) elaborado e implementado pelo LIRN, utilizando chaves dicotômicas apropriadas. Para a Reação em Cadeia pela Polimerase, os ectoparasitas foram processados individualmente ou reunidos em grupos de acordo com sexo, estádio de desenvolvimento (adulto, larva e ninfa) e grau de ingurgitamento, constituindo as amostras dos vetores (APÊNDICE A).

\subsection{Diagnóstico laboratorial}

\subsubsection{Soros caninos}

\subsubsection{Pesquisa sorológica}

Os soros foram processados para pesquisa de anticorpos IgG anti-Rickettsia rickettsii através da técnica de Imunofluorescência Indireta (RIFI). Seguiu-se a 
metodologia do kit diagnóstico para RIFI do Laboratório Füller, dos EUA, que tem como antígeno $R$. rickettsii. Alíquotas das amostras de soro foram diluídas em PBS (solução fosfato tamponada) e colocadas individualmente em cada um dos 12 orifícios da lâmina do kit comercial para possibilitar a fixação de anticorpos. As lâminas foram colocadas em câmara úmida em estufa a $37^{\circ} \mathrm{C}$, durante 30 minutos. A seguir, foram lavadas com PBS seguido de água destilada, ficando em repouso até a secagem total. A cada orifício foi adicionado o conjugado específico constante no kit. Seguiu-se uma nova incubação e lavagem, sendo a lâmina posta em câmara escura até que ficasse seca. Para a leitura, cada poço recebeu uma gota de glicerina e foi coberto por uma lamínula. O título uniforme padrão para situações clínicas foi baseado nas recomendações da OPAS/OMS (2004), sendo considerados positivos para Rickettsia sp. os soros diluídos a 1:64 que foram reativos. Os soros reativos a 1:64 foram testados em diluições seriadas $(1: 64,1: 128,1: 256,1: 512$ e 1:1024). A leitura foi feita em microscópio para imunofluorescência com luz ultravioleta (Olympus, BX 40).

\subsubsection{Pesquisa sobre gene riquetsial}

\subsection{Extração do DNA genômico}

O DNA genômico foi extraído das amostras de soro utilizando o kit comercial QIAamp DNA blood mini kit, seguindo o protocolo indicado pelo fabricante e armazenado a $-20{ }^{\circ} \mathrm{C}$.

\subsection{Reação em Cadeia pela Polimerase}

A Reação em Cadeia pela Polimerase (PCR) foi realizada nas 172 amostras caninas. Foram utilizados oligonucleotídeos gênero-específicos (CS2 e CS4) para detecção de Rickettsia spp que amplificam fragmentos do gene gltA, que codifica a enzima citrato sintase (AZAD et al.,1990). Também foram utilizados oligonucleotídeos grupo-específicos (190), para detecção de riquétsias do Grupo Febre Maculosa (GFM) que amplificam fragmentos do gene OmpA codificador de proteínas externas de membrana de riquétsias (LABRUNA et al., 2004b; REGNERY; SPRUILL; PLIKAYTIS, 1991). O preparo das soluções e as condições das corridas de PCR foram adequados para cada tipo de gene pesquisado. Nas reações de PCR foram utilizados 10 
picomoles de cada oligonucleotídeo; $200 \mu \mathrm{M}$ de cada dNTP; 1X de tampão 10X (Tris$\mathrm{HCl} 200 \mathrm{mM}$ pH 8,4; $\mathrm{KCl} 500 \mathrm{mM}) ; 1,5 \mathrm{mM}$ de $\mathrm{MgCl}_{2} ; 1,25 \mathrm{U}$ de Taq DNA polimerase e água deionisada a fim de completar a reação para o volume de $25 \mu \mathrm{l}$. Como controle positivo, foi utilizado DNAg de R. rickettsii e como controle negativo, água deionizada. As amostras foram submetidas à eletroforese em gel de agarose $2 \%$, com adição de brometo de etídeo para permitir visualização das bandas em luz ultravioleta (SAMBROOK; RUSSEL, 2001). A descrição dos oligonucleotídeos utilizados consta na Tabela 1.

Tabela 1 - Oligonucleotídeos utilizados nos ensaios moleculares

\begin{tabular}{|c|c|c|c|}
\hline Gene & Oligonucleotídeo & Sequência de nucleotídeo (5'-3') & Fragmento \\
\hline \multirow[t]{2}{*}{$o m p A^{a}$} & $\operatorname{Rr} 190.70 \mathrm{p}$ & ATGGCGAATATTTCTCCAAAA & \multirow[b]{2}{*}{532} \\
\hline & $\operatorname{Rr} 190.602 \mathrm{n}$ & AGTGCAGCATTCGCTCCCCCT & \\
\hline \multicolumn{4}{|l|}{ gltA } \\
\hline \multirow{2}{*}{$1^{\mathrm{a}}$} & CS2-78 & GCAAGTATCGGTGAGGATGTAAT & \multirow[b]{2}{*}{401} \\
\hline & $\mathrm{CS} 2-323$ & GCTTCСТTAАAАTTCAATAAATCAGGAT & \\
\hline \multirow{2}{*}{$2^{\mathrm{b}}$} & CS4-239 & GCTCTTCTCATCCTATGGCTATTAT & \multirow[b]{2}{*}{834} \\
\hline & CS4-1069 & CAGGGTCTTCGTGCATTTCTT & \\
\hline \multirow{4}{*}{$3^{c}$} & CS-5 & GAGAGAAAATTATATCCAAATGTTGAT & \multirow[b]{2}{*}{147} \\
\hline & CS-6 & AGGGTCTTCGTGCATTTCTT & \\
\hline & VNTR $^{d}$ B F & AGCCTTAGATAATGTCTTAAC & \multirow[b]{2}{*}{214} \\
\hline & VNTR $^{\mathrm{d}}$ B R & CATGGCTTCAAAAAAAGAACC & \\
\hline
\end{tabular}

Fonte: ${ }^{\mathrm{a}}$ Regnery; Spruill; Plikaytis, $1991 ;{ }^{\mathrm{b}}$ Labruna et al., 2004a; ${ }^{\mathrm{c}}$ Labruna et al., 2004b; ${ }^{\mathrm{d}}$ Eremeeva et al., 2006 ; Wikswo et al., 2007.

\subsection{PCR em Tempo Real}

As reações para detecção do gene riquetsial $g l t$ A utilizaram os oligonucleotídeos CS-5 e CS-6 (Tabela 1) e a sonda interna fluorogênica (5’ - 56 FAM - CAT TGT GCC ATC CAG CCT ACG GT - BHQ 1 - 3'), de acordo com protocolo já estabelecido (LABRUNA et al., 2004b). Para a reação, empregou-se QuantiMix Easy Probes kit (Biotools S.A., Valle de Tobalina, Madri, Espanha), de acordo com o procedimento descrito pelo fabricante, utilizando $2 \mu \mathrm{l}$ de amostra por reação, num volume final de 20 $\mu$ l. O programa térmico utilizou desnaturação inicial 2 minutos a $95^{\circ} \mathrm{C}$ seguidos de 50 ciclos com desnaturação a $95{ }^{\circ} \mathrm{C}$ durante a 15 segundos, anelamento a $55^{\circ} \mathrm{C}$ durante 15 segundos e extensão a $68{ }^{\circ} \mathrm{C}$ durante 20 segundos, realizada por um termociclador para qPCR, modelo Mastercycler ${ }^{\circledR}$ ep realplex ${ }^{2}$ (Eppendorf, Hamburgo, Hamburgo, 
Alemanha). Todas as amostras foram analisadas em triplicata. Como controle negativo, as reações foram realizadas utilizando-se água deionizada. Como controle positivo, foi utilizado DNA plasmidial contendo o fragmento do gene gltA de $R$. rickettsii $\left(5,3 \times 10^{7}\right.$ a $5,3 \times 10^{2}$ cópias). Para estabelecimento da curva padrão, DNA plasmidial foi quantificado e o número de moléculas foi calculado a partir da fórmula de Avogadro. A partir daí, foram feitas diluições seriadas de DNA plasmidial para estabelecimento da curva padrão, que variou de $5,3 \times 10^{7}$ a $5,3 \times 10^{2}$ cópias.

\subsubsection{Artrópodes}

\subsubsection{Pesquisa sobre genes riquetsiais}

\subsection{Extração do DNA genômico}

Os ectoparasitas coletados em Petrópolis foram processados individualmente ou reunidos em grupos que constituíram as amostras de potenciais vetores, totalizando o número de 358 espécimes. Microtubos que continham os animais foram parcialmente submersos em nitrogênio líquido e macerados com bastão de vidro estéril. O DNAg de carrapatos e pulgas foi extraído pela técnica de extração por $\mathrm{NaCl}$ (ALJANABI; MARTINEZ, 1997), utilizando digestão com proteinase $\mathrm{K}$ e precipitação com isopropanol, e armazenado a $-20{ }^{\circ} \mathrm{C}$.

\subsection{Amplificação genômica}

Visando contornar a baixa disponibilidade de DNA genômico de Rickettsia sp. em amostras naturalmente infectadas e as limitações na obtenção de cultura in vitro, foi utilizada estratégia de amplificação genômica utilizando WGA (Whole-Genome Amplification). A pré-amplificação genômica foi realizada a partir de 2,5 $\mu \mathrm{l}$ de DNA genômico com a tecnologia de amplificação por deslocamento múltiplos (multiple displacement amplification) descrita por Dean et al. (2002), empregando-se mini-kits REPLI-g (Qiagen, Valencia, CA. Estados Unidos.). O produto de amplificação resultante $(20 \mu \mathrm{l})$ foi utilizado como DNA molde para PCR, sequenciamento e tipagem molecular de algumas amostras. 
2.3.2.1.3 PCR para detecção de genes riquetsiais

Foi procedida tal qual descrito na seção 2.3.1.2.2. A amplificação do fragmento de interesse foi confirmada por eletroforese em gel de agarose a 2,0\%.

\subsection{Clonagem e Análise de sequências}

O produto da PCR, recortado a partir do gel, foi purificado com NucleoSpin Extract II kit (Macherey Nagel, Düren, North Rhine-Westphalia, Alemanha), ligado ao plasmídeo vetor pGEM-T Easy Vector (Promega Corporation, Madison, WI, Estados Unidos) e a seguir clonado utilizando bactéria Escherichia coli (linhagem DH5 $\alpha$ ) (SAMBROOK; RUSSEL, 2001). Foram utilizados dois oligonucleotídeos (CS2 e CS4) para obtenção das sequências. Foram utilizadas sequências de três a oito clones.

As amostras foram submetidas à reação de sequenciamento, utilizando concentrações de 1 a $5 \mu \mathrm{l}$ do produto de PCR purificado ou de plasmídeo vetor, $0,75 \mu \mathrm{l}$ de Big Dye Terminator Cycle Sequencing Ready Reaction Kit v. 3.1 (Applied Biosystems, Foster City, CA, Estados Unidos), 3,25 $\mu 1$ de tampão Save Money (1 Molar Tris- $\mathrm{HCl} \mathrm{pH}$ 9,0, $50 \mathrm{mM} \mathrm{MgCl2}$ ) e $5 \mathrm{mM}$ de oligonucleotídeo, além de água ultrapura q.s.p, $10 \mu$ l. Cada fragmento foi sequenciado em ambas as direções, em termociclador GeneAmp PCR 9700 (Applied Biosystems, Estados Unidos). A reação foi realizada nas seguintes condições: desnaturação inicial a $96{ }^{\circ} \mathrm{C}$ por 1 minuto, seguido de 30 ciclos com desnaturação a $96{ }^{\circ} \mathrm{C}$ por 15 segundos, anelamento a $50{ }^{\circ} \mathrm{C}$ por 15 segundos, extensão a $60^{\circ} \mathrm{C}$ por 4 minutos.

O produto da reação de sequenciamento foi precipitado adicionando-se $90 \mu \mathrm{lde}$ isopropanol a 66\%. O homogeneizado foi incubado por 15 minutos, à temperatura ambiente, sob proteção da luz e centrifugado a 2464 g por 60 minutos. O sobrenadante foi removido por inversão da placa e o sedimento lavado com $150 \mu 1$ de isopropanol a $75 \%$. A placa foi então centrifugada a $2464 \mathrm{~g}$ durante 30 minutos. O sobrenadante foi descartado e a placa colocada invertida sobre papale absorvente para um pulso de $45 \mathrm{~g}$ por 30 segundos. Todo o etanol foi removido, pois qualquer etanol residual resultaria em manchas fluorescentes. As amostras foram secas em temperatura ambiente e protegida da luz. O produto foi eluído com $10 \mu$ de tampão de amostra contendo Formamida Hi-Di (Applied Biosystems, Carlsbad, CA, Estados Unidos). Após, as 
amostras foram aquecidas a $95{ }^{\circ} \mathrm{C}$ por 5 minutos, rapidamente transferidas para o gelo e então colocadas no sequenciador capilar ABI310 (Applied Biosystems, Estado Unidos), utilizando BigDyeTM Terminator-Cycle Sequencing Ready Reaction kit (Applied Biosystems, Foster City, CA, Estados Unidos). As sequências foram lidas por sequenciador automático ABI Prism 3100 Genetic Análiser (Applied Biosystems, Estados Unidos).

As sequências obtidas foram editadas manualmente empregando-se o programa SeqMan ${ }^{\mathrm{TM}}$ II, Expert Sequence Analysis Software 5.00 ${ }^{\odot}$ 1989-2001, (DNASTAR Inc. Madison, WI, Estados Unidos). A avaliação da similaridade das sequências de nucleotídeo foi obtida através da análise comparativa com as sequências existentes no banco de dados GenBank com o auxílio do programa BLASTN (NACIONAL CENTER FOR BIOTECHNOLOGY INFORMATION, 2013).

Para os alinhamentos e filodendogramas, foram utilizadas sequências espécies de riquétsias existentes no GenBank, e realizado com auxílio do software MEGA 5.10 (TAMURA et al., 2011).

Os filodendogramas foram construídos pelos métodos de Distância (Neighbor Joining), e o cálculo de distância foi realizado através do algoritmo kimura 2 parâmetros. O suporte dos ramos das árvores filogenéticas foi calculado, utilizando um bootstrap de 1000 réplicas.

\subsubsection{Tipagem de Rickettsia rickettsii}

\subsubsection{Origem das amostras analisadas}

A pesquisa de sequências nucleotídicas em repetição de um fragmento intergênico do genoma de $R$. rickettsii (VNTR) foi realizada em amostras diagnosticadas previamente, através da análise de algumas sequências do genoma da bactéria (GEHRKE, 2010), em material procedente de diferentes localidades do estado do Rio de Janeiro. O DNAg destas amostras foi extraído de equinos, caninos e carrapatos pertencentes a diferentes gêneros: Amblyomma cajennense, Rhipicephalus sanguineus, Boophilus microplus, Anocentor nitens, e encontrava-se armazenado no Departamento de Parasitologia/ICB-USP. Também foram incluídas amostras diagnosticadas como $R$. rickettsii na presente pesquisa. Também foram analisadas outras espécies de riquétsias, Rickettsia felis (presente pesquisa), Rickettsia parkeri, Rickettsia 
riphicephali (gentilmente cedidas por A.I.Duré - Fundação Ezequiel Dias, Serviço de Virologia e Riquetsioses), R. belli (MOURA, 2012).

\subsubsection{PCR para pesquisa de fragmento repetitivo (VNTR) na região intergênica B}

Com objetivo de amplificar o fragmento da região intergênica $\mathrm{B}$, de Rickettsia rickettsii que contém microssatélites, utilizamos oligonucleotídeos "VNTRB" (Tabela 1), baseados no estudo de Eremeeva (2006) e Wisko (2007) para detecção e genotipagem de $R$. rickettsii. Foi realizado alinhamento dos mesmos a sequências de diferentes cepas de $R$. rickettsii depositadas no GenBank, com auxílio do programa Bioedit Sequence Alignment Editor (HALL, 1999), através do qual foi constatada a necessidade de correção de uma base nucleotídica na sequência do oligonucleotídeo (APÊNDICE B). Para estabelecimento do protocolo de amplificação, foram realizados repetidos testes com variações de volume de reagentes e diferentes temperaturas do ciclo, através de Gradiente de Temperatura, para encontro da temperatura ótima para o anelamento. Nas reações de PCR foram utilizados 10 pmoles de cada oligonucleotídeo e Quantimix Easy Probes de acordo com as instruções do fabricante. O protocolo estabelecido para amplificação foi com desnaturação inicial a $94{ }^{\circ} \mathrm{C}$ por 4 minutos, seguida de 45 ciclos com desnaturação a $95{ }^{\circ} \mathrm{C}$ por 45 segundos, anelamento variando de $46,1^{\circ} \mathrm{C}$ a $52{ }^{\circ} \mathrm{C}$ por 30 segundos e extensão a $72{ }^{\circ} \mathrm{C}$ por 45 segundos. A etapa final foi realizada a $72{ }^{\circ} \mathrm{C}$ por 10 minutos. A amostra foi submetida à eletroforese em gel de agarose 1,5\%. A amostra $R$. rickettsii (BME), cultivada em células de Boophilus microplus foi utilizada como controle positivo. Água deionizada como controle negativo.

\subsubsection{Sequenciamento e Análise de sequências}

As etapas de clonagem e sequenciamento foram realizadas como descrito na seção 2.3.2.1.4. 


\section{RESULTADOS}

\subsection{Soros caninos}

\subsubsection{Pesquisa sorológica}

Foram coletadas 172 amostras de soro canino nos seis municípios das regiões estudadas do Estado do Rio de Janeiro. Dentre elas, 117 (68,0\%) reagiram positivamente (título $\geq 1: 64$ ). Todas as localidades estudadas apresentaram animais reagentes.

A maior prevalência em um município foi verificada em Arraial do Cabo, onde $88,9 \%$ das amostras coletadas apresentou título $\geq 1: 64$ (Tabela 2).

Tabela 2 - Prevalência de amostras de soro canino positivas para a presença de anticorpos anti-Rickettsia sp. e titulação obtida por localidadade segundo Reação de Imunofluorescência Indireta (RIFI), em municípios do Estado do Rio de Janeiro, Brasil

\begin{tabular}{lcccccccc}
\hline \multirow{2}{*}{ Municípios } & \multicolumn{2}{c}{$\mathbf{N}^{\mathbf{0}}$ de amostras } & $\mathbf{P}$ & \multicolumn{5}{c}{ Titulação } \\
\cline { 2 - 3 } & Coletadas & Reagentes & $(\%)$ & $\mathbf{1 / 6 4}$ & $\mathbf{1 / 1 2 8}$ & $\mathbf{1 / 2 5 6}$ & $\mathbf{1 / 5 1 2}$ & $\mathbf{1 / 1 0 2 4}$ \\
\hline Arraial do Cabo & 18 & 16 & 88,9 & $4(22,2)$ & $0(0,0)$ & $11(61,1)$ & $1(5,6)$ & $0(0,0)$ \\
\hline Paraíba do Sul & 6 & 5 & 83,3 & $0(0,0)$ & $0(0,0)$ & $0(0,0)$ & $1(16,6)$ & $4(66,6)$ \\
\hline Mangaratiba & 10 & 7 & 70,0 & $1(10,0)$ & $0(0,0)$ & $4(40,0)$ & $1(10,0)$ & $1(10,0)$ \\
\hline Japeri & 4 & 2 & 50,0 & $0(0)$ & $0(0,0)$ & $2(50,0)$ & $0(0)$ & $0(0,0)$ \\
\hline Queimados & 5 & 4 & 80,0 & $4(80,0)$ & $0(0,0)$ & $0(0,0)$ & $0(0,0)$ & $0(0,0)$ \\
\hline Rio de Janeiro & 129 & 83 & 64,3 & $24(18,6)$ & $13(10,0)$ & $22(17,0)$ & $15(11,6)$ & $9(6,9)$ \\
Z. Central & 2 & 1 & 50,0 & $0(0,0)$ & $1(50,0)$ & $0(0,0)$ & $0(0,0)$ & $0(0,0)$ \\
\hline Z. Norte & 34 & 12 & 35,3 & $4(11,7)$ & $2(5,8)$ & $2(5,8)$ & $3(8,83)$ & $1(2,9)$ \\
\hline Z. Oeste & 75 & 58 & 77,3 & $16(21,3)$ & $8(10,6)$ & $19(25,3)$ & $8(10,66)$ & $7(9,3)$ \\
\hline Z. Sul & 18 & 12 & 66,7 & $4(22,2)$ & $2(11,1)$ & $1(5,6)$ & $4(22,2)$ & $1(5,6)$ \\
\hline TOTAL & $\mathbf{1 7 2}$ & $\mathbf{1 1 7}$ & $\mathbf{6 8 , 0}$ & $\mathbf{3 3}$ & $\mathbf{1 3}$ & $\mathbf{3 9}$ & $\mathbf{1 8}$ & $\mathbf{1 4}$ \\
\hline P: prevalência; Z: zona administrativa do município de Rio de Janeiro. & & &
\end{tabular}

A prevalência de animais positivos por município com relação ao total de amostras coletadas é dada na Tabela 3. 
Tabela 3 - Prevalência de amostras de soro canino positivas para a presença de anticorpos anti-Rickettsia sp. e frequência de títulos no estudo, detectados pela Reação de Imunofluorescência Indireta (RIFI), em municípios do Estado do Rio de Janeiro, Brasil

\begin{tabular}{|c|c|c|c|c|c|c|c|c|}
\hline \multirow[b]{2}{*}{ Municípios } & \multicolumn{2}{|c|}{$\mathrm{N}^{\circ}$ de amostras } & \multirow{2}{*}{$\begin{array}{c}\mathbf{P} \\
(\%) \\
\end{array}$} & \multicolumn{5}{|c|}{ Titulação } \\
\hline & Coletadas & Reagentes & & $1 / 64$ & $1 / 128$ & $1 / 256$ & $1 / 512$ & $1 / 1024$ \\
\hline Arraial do Cabo & 18 & 16 & 9,3 & $4(2,3)$ & $0(0,0)$ & $11(6,4)$ & $1(0,6)$ & $0(0,0)$ \\
\hline Paraíba do Sul & 6 & 5 & 2,9 & $0(0,0)$ & $0(0,0)$ & $0(0,0)$ & $1(0,6)$ & $4(2,3)$ \\
\hline Mangaratiba & 10 & 7 & 4,1 & $1(0,6)$ & $0(0,0)$ & $4(2,3)$ & $1(0,6)$ & $1(0,6)$ \\
\hline Japeri & 4 & 2 & 1,2 & $0(0,0)$ & $0(0,0)$ & $2(1,2)$ & $0(0,0)$ & $0(0,0)$ \\
\hline Queimados & 5 & 4 & 2,3 & $4(2,3)$ & $0(0,0)$ & $0(0,0)$ & $0(0,0)$ & $0(0,0)$ \\
\hline Rio de Janeiro & 129 & 83 & 48,2 & $24(14)$ & $13(7,6)$ & $22(12,8)$ & $15(8,7)$ & $9(5,2)$ \\
\hline Z. Central & 2 & 1 & 0,5 & $0(0,0)$ & $1(0,6)$ & $0(0,0)$ & $0(0,0)$ & $0(0,0)$ \\
\hline Z. Norte & 34 & 12 & 7,0 & $4(2,3)$ & $2(1,2)$ & $2(1,2)$ & $3(1,7)$ & $1(0,6)$ \\
\hline Z. Oeste & 75 & 58 & 33,7 & $16(9,3)$ & $8(4,7)$ & $19(11,0)$ & $8(4,7)$ & $7(4,1)$ \\
\hline Z. Sul & 18 & 12 & 7,0 & $4(2,3)$ & $2(1,2)$ & $1(0,6)$ & $4(2,3)$ & $1(0,6)$ \\
\hline TOTAL & 172 & 117 & 68 & $33(19,2)$ & $13(7,6)$ & $39(22,7)$ & $18(10,5)$ & $14(8,1)$ \\
\hline
\end{tabular}

P: Prevalência; Z: zona administrativa do município de Rio de Janeiro.

\subsubsection{Detecção de gene riquetsial PCR e PCR em Tempo Real}

\section{$\underline{3.1 .2 .1 \mathrm{PCR}}$}

Em nenhuma das 172 amostras de soros submetidas à PCR para detecção de genes riquetsias gltA ou ompA foi possível observar amplificação de fragmento de tramanho esperado. Repetições dos ensaios foram realizadas para dirimir dúvidas, e os resultados mantiveram-se negativos.

\subsubsection{PCR em Tempo Real}

$\mathrm{Na}$ análise através de PCR em Tempo Real, em quatro amostras de soros caninos foi possível detectar o gene gltA conforme assinalado na Tabela 4. Com exceção da amostra A17C24, todas as amostras apresentaram sorologia positiva. 
Tabela 4 - Amostras de soro caninos com amplificação de gene rickettsial ( $g l t \mathrm{~A}$ ) procedentes do Estado do Rio de Janeiro

\begin{tabular}{|c|c|c|c|c|c|c|}
\hline $\begin{array}{l}\text { Colets } \\
\text { Data }\end{array}$ & Município & Bairro & Código & Hospedeiro & $\begin{array}{l}\text { Ensaios } \\
\text { Sorologia* }\end{array}$ & qPCR** \\
\hline 2008 & Japeri & $\begin{array}{l}\text { Engenheiro } \\
\text { Pedreira }\end{array}$ & $\mathrm{A} 71 \mathrm{C} 03$ & $\begin{array}{l}\text { Canis } \\
\text { familiaris }\end{array}$ & $1 / 256$ & + \\
\hline 2008 & $\begin{array}{l}\text { Rio } \\
\text { Janeiro }\end{array}$ & $\begin{array}{l}\text { Vargem } \\
\text { Grande }\end{array}$ & A17C07 & $\begin{array}{l}\text { Canis } \\
\text { familiaris }\end{array}$ & $1 / 1024$ & + \\
\hline 2008 & $\begin{array}{ll}\text { Rio } & \text { de } \\
\text { Janeiro } & \end{array}$ & Gávea & A17C11 & $\begin{array}{l}\text { Canis } \\
\text { familiaris }\end{array}$ & $1 / 128$ & + \\
\hline 2008 & $\begin{array}{l}\text { Rio de } \\
\text { Janeiro }\end{array}$ & $\begin{array}{l}\text { Ilha do } \\
\text { Governador }\end{array}$ & A17C24 & $\begin{array}{l}\text { Canis } \\
\text { familiaris }\end{array}$ & - & + \\
\hline
\end{tabular}

\subsubsection{Análise das sequências}

Não foi possível analisar a sequência de nucleotídeos do gene gltA das quatro amostras com amplificação do fragmento. Repetições dos ensaios foram realizadas para dirimir dúvidas, e os resultados mantiveram-se negativos.

\subsection{Artrópodes}

\subsubsection{Identificação}

Um total de 358 ectoparasitas foi coletado no município de Petrópolis, parasitando 11 equinos, 8 bovinos, 6 caninos, 5 humanos, um felino, bem com livres no ambiente, nos estádios de ninfa ou adulto (Tabela 5). As espécies de ectoparasitas identificadas estão descritas na Tabela 6. Os espécimes foram divididos em 262 amostras. 
Tabela 5 - Frequência absoluta e relativa de potenciais vetores coletados, segundo hospedeiro presente no município de Petrópolis, investigado para Febre Maculosa Brasileira, no estado do Rio de Janeiro

\begin{tabular}{|c|c|c|c|c|c|c|}
\hline \multirow{2}{*}{ HOSPEDEIRO (n) } & \multicolumn{2}{|c|}{ CARRAPATOS } & \multicolumn{2}{|c|}{ PULGAS } & \multicolumn{2}{|c|}{ TOTAL } \\
\hline & $N$ & $\%$ & $n$ & $\%$ & $N$ & $\%$ \\
\hline Equus caballus (11) & 79 & 23,9 & 0 & 0,0 & 79 & 22,1 \\
\hline Bos taurus (8) & 23 & 6,9 & 0 & 0,0 & 23 & 6,4 \\
\hline Canis familiaris (6) & 100 & 30,2 & 23 & 85,2 & 123 & 34,4 \\
\hline Homo sapiens (5) & 19 & 5,7 & 0 & 0,0 & 19 & 5,3 \\
\hline Felis catus (1) & 0 & 0,0 & 4 & 14,8 & 4 & 1,1 \\
\hline Grama/pasto & 110 & 33,2 & 0 & 0,0 & 110 & 30,7 \\
\hline TOTAL & 331 & 100,0 & 27 & 100,0 & 358 & 100,0 \\
\hline
\end{tabular}

n: frequência absoluta; \% frequência relativa de carrapatos e pulgas coletados

Tabela 6 - Frequência absoluta de potenciais vetores coletados no município de Petrópolis investigados para Febre Maculosa Brasileira, no estado do Rio de Janeiro

\begin{tabular}{llllll}
\hline Ectoparasita & M & F & N & Total (n) & Amostras \\
\hline Anocentor nitens & 1 & 22 & 6 & 29 & 29 \\
Amblyomma cajennense & 41 & 14 & 117 & 172 & 81 \\
Boophilus microplus & 1 & 23 & 1 & 25 & 25 \\
Rhipicephalus sanguineus & 31 & 74 & 0 & 105 & 105 \\
Ctenocephalides felis & 15 & 11 & 0 & 27 & 22 \\
\hline Total & $\mathbf{8 9}$ & $\mathbf{1 4 4}$ & $\mathbf{1 2 4}$ & $\mathbf{3 5 8}$ & $\mathbf{2 6 2}$ \\
\hline
\end{tabular}

M: machos; F: fêmeas; N: ninfas; (n): número de espécimes

\subsubsection{Detecção de gene riquetsial PCR e PCR em Tempo Real}

\subsubsection{PCR}

Nas 262 amostras, organizadas a partir dos 358 ectoparasitos, não foi possível a detecção do gene gltA nas várias repetições realizadas dos ensaios.

\subsubsection{PCR em Tempo Real}

Foram estabelecidos os pontos da curva seriada, partindo de DNA plasmidial conhecido (Figura 3). Nos ensaios com as 262 amostras analisadas, em 16 (6,10\%) houve amplificação do fragmento do gene pesquisado. Como ilustração, a Figura 4 apresenta o 
gráfico gerado durante a reação de PCR em Tempo Real para algumas amostras (oligonucleotídeos CS5 e CS6, que flanqueiam uma região do gene gltA).

Figura 3 - Curvas de diluição seriada (curva padrão) para PCR em Tempo Real

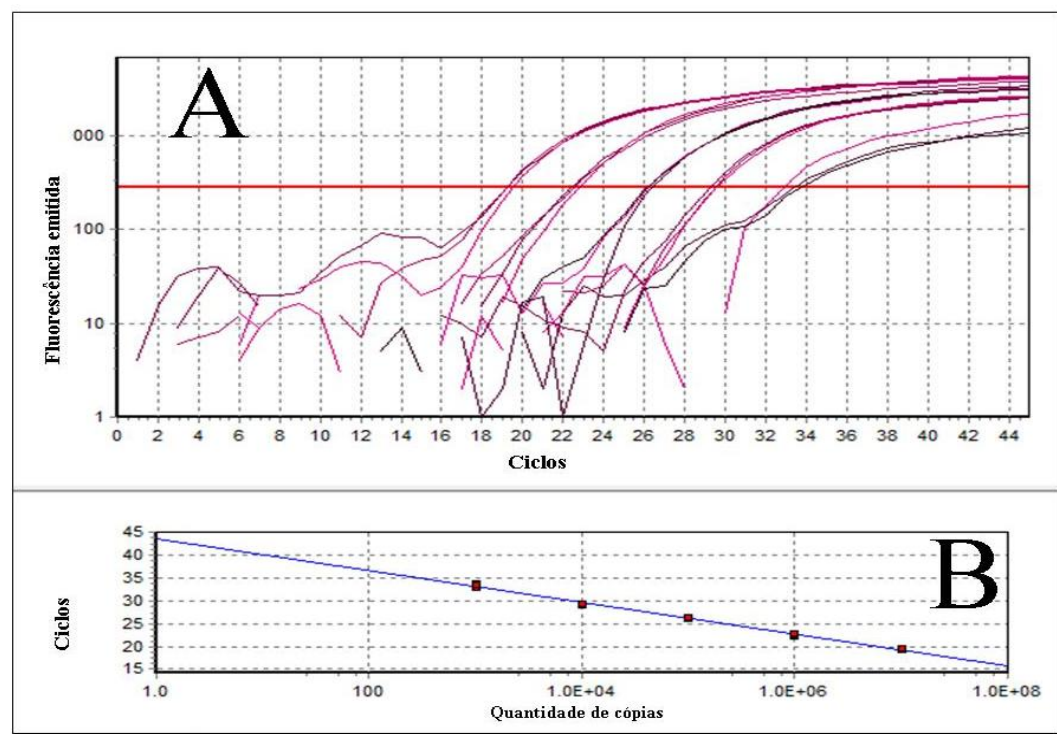

A: Perfil de amplificação da curva seriada; B: Reta gerada pela curva de diluição para determinação dos valores de eficiência da reação ( $\mathrm{r}^{2}$ e Eficiência).

Figura 4 - Curvas de amplificação de amostras de ectoparasitas do município de Petrópolis, Estado de Rio de Janeiro

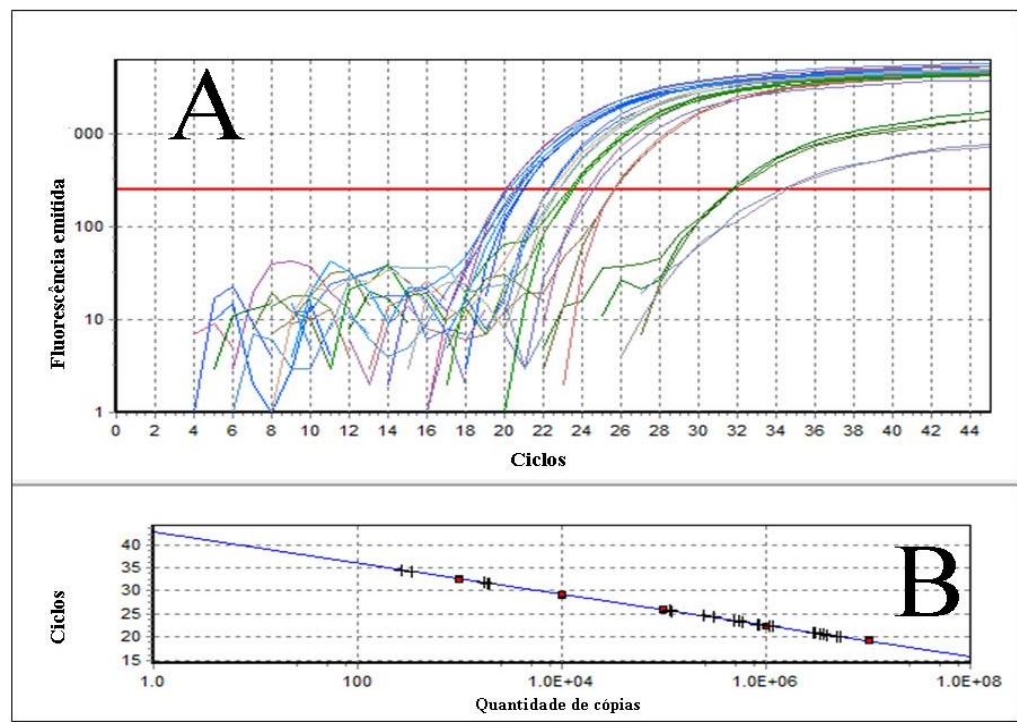

A: Perfil de amplificação das curvas das amostras; B: Reta de eficiência da reação e perfil das amostras que amplificaram.

Na Tabela 7 estão discriminados os resultados obtidos por PCR em Tempo Real (gltA), segundo espécie de artrópode e os códigos das amostras positivas. Nela também constam os dados sobre hospedeiros dos artrópodes examinados bem como a organização das amostras segundo estádio e gênero. No total, amplificaram o fragmento do gene, 7 amostras 
de A. cajennense, sendo 6 compostas por ninfas coletadas no ambiente e um macho coletado em humano. Das 9 amostras de $C$. felis, 2 foram coletadas sobre um felino, 6 em um canino e uma em outro canino.

Tabela 7 - Pesquisa de gene riquetsial em amostras de potenciais vetores, por PCR em Tempo Real, segundo hospedeiro, investigados para Febre Maculosa Brasileira, no município de Petrópolis, região Serrana do Estado do Rio de Janeiro

\begin{tabular}{|c|c|c|c|c|c|c|c|c|}
\hline \multirow[t]{2}{*}{ HOSPEDEIRO (n) } & \multicolumn{8}{|c|}{ AMOSTRA } \\
\hline & ESPÉCIE & M & $\mathrm{F}$ & $\mathrm{N}$ & TOTAL & \multicolumn{2}{|r|}{$\begin{array}{c}\text { POS(n) } \\
\text { gltA }\end{array}$} & CÓDIGO \\
\hline Livre no ambiente & A. cajennense & 0 & 0 & 110 & 110 & 22 & 6 & $\begin{array}{l}1884 \mathrm{E} \\
1884 \mathrm{~F} \\
1882 \mathrm{~B} \\
1882 \mathrm{D} \\
1882 \mathrm{E} \\
1882 \mathrm{~F}\end{array}$ \\
\hline \multirow{4}{*}{ Canis familiaris (6) } & A. cajennense & 2 & 0 & 1 & 3 & 3 & 0 & \multirow{4}{*}{$\begin{array}{l}\text { LIS 04A } \\
\text { LIS 04B } \\
\text { LIS 04D } \\
\text { LIS 04E } \\
\text { LIS 04F } \\
\text { LIS 04G } \\
\text { LIS 273-4 }\end{array}$} \\
\hline & B.microplus & 0 & 0 & 1 & 1 & 1 & 0 & \\
\hline & C. felis & 14 & 9 & 0 & 23 & 18 & 7 & \\
\hline & R.sanguineus & 27 & 69 & 0 & 96 & 96 & 0 & \\
\hline \multirow{4}{*}{ Equus caballus (11) } & A. cajennense & 34 & 11 & 0 & 45 & 45 & 0 & \\
\hline & A. nitens & 1 & 21 & 6 & 28 & 28 & 0 & \\
\hline & B.microplus & 0 & 2 & 0 & 2 & 2 & 0 & \\
\hline & R.sanguineus & 3 & 1 & 0 & 4 & 4 & 0 & \\
\hline \multirow[t]{2}{*}{ Homo sapiens (5) } & A. cajennense & 6 & 3 & 6 & 15 & 12 & 1 & $1887 \mathrm{~L}$ \\
\hline & B.microplus & 0 & 4 & 0 & 4 & 4 & 0 & \\
\hline \multirow{3}{*}{ Bos taurus (8) } & A.nitens & 0 & 1 & 0 & 1 & 1 & 0 & \\
\hline & B.microplus & 1 & 17 & 0 & 18 & 18 & 0 & \\
\hline & R.sanguineus & 0 & 4 & 0 & 4 & 4 & 0 & \\
\hline \multirow[t]{2}{*}{ Felis catus (1) } & C. felis & 1 & 3 & 0 & 4 & 4 & 2 & $\begin{array}{l}\text { LIS 02A } \\
\text { LIS 02D }\end{array}$ \\
\hline & TOTAL & 89 & 145 & 124 & 358 & 262 & 16 & \\
\hline
\end{tabular}

M: machos; F: fêmeas; N: ninfas; (n): número de hospedeiros examinados para coleta de vetores; (n)*: números de amostras compostas para as análises utilizando PCR em Tempo Real; POS(n): número de amostras com amplificação do gene riquetsial, gltA. 


\subsubsection{Análise das sequências}

Foi possível analisar a sequência de nucleotídeos do fragmento do gene gltA de 15 amostras, correspondendo a 5,72\% do total de amostras de artrópodes submetidas à PCR As sequências do gene gltA de riquétsias, detectadas em 6 amostras de carrapato apresentaram 99\% ou 100\% de identidade com $R$. rickettsii das cepas, Sheila Smith (CP000848.1), Brazil (CP003305.1), Hauke (CP003318.1), Arizona (CP003307.1), Colômbia, (CP003306.1), Iowa (CP000766.2) e R.rickettsii isolate 2395 (JN375499.1), disponíveis no GenBank. As 9 amostras de pulgas, apresentaram $99 \%$ ou $100 \%$ de identidade com R.felis cepas: URRWXCal2 (CP000053.1) e California 2 (AF210692.1) disponíveis no GenBank (Tabela 8). Os valores de identidade indicam a potencial presença da espécie de Rickettsia no artrópode. 
Tabela 8 - Identificação de riquétsia em ectoparasitas procedentes do município de Petrópolis, região Serrana do Estado do Rio de Janeiro

\begin{tabular}{|c|c|c|c|c|c|c|c|c|c|c|}
\hline \multicolumn{4}{|c|}{ Coleta } & \multicolumn{3}{|c|}{ Ectoparasitas } & \multicolumn{2}{|c|}{ Ensaios } & \multicolumn{2}{|c|}{ Sequenciamento } \\
\hline Data & Local & Hospedeiro & Vida Livre & Espécies & Composição & Código & qPCR & PCR & Identidade CS2 & Identidade CS4 \\
\hline $03 / 11 / 2005$ & Itaipava 1 & $\begin{array}{l}\text { Canis } \\
\text { familiaris }\end{array}$ & & C. felis & $1 \mathrm{~F}$ & LIS 04A & + & + & $\begin{array}{l}\text { R.felis } \\
339 / 402(99 \%)^{* *}\end{array}$ & $\begin{array}{l}\text { R.felis } \\
693 / 693(100 \%)^{* *}\end{array}$ \\
\hline $03 / 11 / 2005$ & Itaipava 1 & $\begin{array}{l}\text { Canis } \\
\text { familiaris }\end{array}$ & & C. felis & $1 \mathrm{~F}$ & LIS 04B & + & + & $\begin{array}{l}\text { R.felis } \\
339 / 402(99 \%)^{* *}\end{array}$ & $\begin{array}{l}\text { R.felis } \\
686 / 686(100 \%)^{* *}\end{array}$ \\
\hline $03 / 11 / 2005$ & Itaipava 1 & $\begin{array}{l}\text { Canis } \\
\text { familiaris }\end{array}$ & & C. felis & $2 \mathrm{M}$ & LIS04D & + & + & $\begin{array}{l}\text { R.felis } \\
339 / 402(99 \%)^{* *}\end{array}$ & $\begin{array}{l}\text { R.felis } \\
676 / 676(100 \%)^{* *}\end{array}$ \\
\hline $03 / 11 / 2005$ & Itaipava 1 & $\begin{array}{l}\text { Canis } \\
\text { familiaris }\end{array}$ & & C. felis & $2 \mathrm{M}$ & LIS 04E & + & + & $\begin{array}{l}\text { R.felis } \\
339 / 402(99 \%)^{* *}\end{array}$ & $\begin{array}{l}\text { R.felis } \\
701 / 701(100 \%)^{* *}\end{array}$ \\
\hline $03 / 11 / 2005$ & Itaipava 1 & $\begin{array}{l}\text { Canis } \\
\text { familiaris }\end{array}$ & & C. felis & $2 \mathrm{M}$ & LIS 04F & + & + & $\begin{array}{l}\text { R.felis } \\
339 / 402(99 \%)^{* *}\end{array}$ & $\begin{array}{l}\text { R.felis } \\
677 / 677(100 \%)^{* *}\end{array}$ \\
\hline $03 / 11 / 2005$ & Itaipava 1 & $\begin{array}{l}\text { Canis } \\
\text { familiaris }\end{array}$ & & C. felis & $2 \mathrm{M}$ & LIS 04G & + & + & $\begin{array}{l}\text { R.felis } \\
339 / 402(99 \%)^{* *}\end{array}$ & $\begin{array}{l}\text { R.felis } \\
677 / 677(100 \%)^{* *}\end{array}$ \\
\hline 03/11/2005 & Itaipava 1 & Felis catus & & C. felis & $1 \mathrm{~F}$ & LIS 02A & + & + & $\begin{array}{l}\text { R.felis } \\
339 / 402(99 \%)^{* *}\end{array}$ & $\begin{array}{l}\text { R.felis } \\
709 / 709(100 \%)^{* *}\end{array}$ \\
\hline $03 / 11 / 2005$ & Itaipava 1 & Felis catus & & C. felis & $1 \mathrm{M}$ & LIS 02D & + & + & $\begin{array}{l}\text { R.felis } \\
339 / 402(99 \%)^{* *}\end{array}$ & \\
\hline $03 / 11 / 2005$ & Itaipava 2 & & grama / pastagem & A. cajennense & $5 \mathrm{~N}$ & $1884 E$ & + & + & & $\begin{array}{l}\text { R. rickettsii } \\
719 / 719(100 \%)^{*}\end{array}$ \\
\hline $05 / 11 / 2005$ & Itaipava 2 & $\begin{array}{l}\text { Homo } \\
\text { sapiens }\end{array}$ & & A. cajennense & $1 \mathrm{M}$ & $1887 \mathrm{~L}$ & + & + & $\begin{array}{l}\text { R. rickettsii } \\
401 / 402(100 \%)^{*}\end{array}$ & $\begin{array}{l}\text { R. rickettsii } \\
582 / 582(100 \%) *\end{array}$ \\
\hline $08 / 11 / 2005$ & Itaipava 2 & & grama / pastagem & A. cajennense & $5 \mathrm{~N}$ & 1882B & + & + & & $\begin{array}{l}\text { R. rickettsii } \\
709 / 710(99 \%)^{*}\end{array}$ \\
\hline 08/11/2005 & Itaipava 2 & & grama / pastagem & A. cajennense & $5 \mathrm{~N}$ & 1882D & + & + & & $\begin{array}{l}\text { R. rickettsii } \\
698 / 698(100 \%)^{*}\end{array}$ \\
\hline $08 / 11 / 2005$ & Itaipava 2 & & grama / pastagem & A. cajennense & $5 \mathrm{~N}$ & $1882 E$ & + & + & - & - \\
\hline $08 / 11 / 2005$ & Itaipava 2 & & grama / pastagem & A. cajennense & $5 \mathrm{~N}$ & $1882 F$ & + & + & & $\begin{array}{l}\text { R. rickettsii } \\
513 / 513(100 \%) *\end{array}$ \\
\hline 16/09/2010 & Carangola & $\begin{array}{l}\text { Canis } \\
\text { familiaris }\end{array}$ & & A. cajennense & $1 \mathrm{~F}$ & LIS 273-4 & N/A & + & & $\begin{array}{l}\text { R.felis } \\
678 / 678(100 \%)^{* *}\end{array}$ \\
\hline
\end{tabular}

Detecção de fragmentos do gene gltA utilizando Reação em Cadeia pela Polimerase - PCR e/ou PCR Quantitativa em Tempo Real - qPCR em amostras de ectoparasitas. M: machos; F: fêmeas; N: ninfas; Itaipava 1: ponto de coleta - União Indústria; Itaipava 2: ponto de coleta - Pousada Capim Limão; N/A: ensaio não aplicado; * Identidade com sequências de Rickettsia rickettsii depositadas no GenBank cepas: Iowa (CP000766.2), Sheila Smith (CP000848.1), Bitterroot (U59729.1); ** Identidade com sequências de Rickettsia felis depositadas no GenBank cepas: URRWXCal2 (CP000053.1) e California 2 (AF210692.1) 


\subsubsection{Análise filogenética}

As espécies de Rickettsia sp disponíveis no GenBank utilizadas para análise das sequências de fragmentos de gltA obtidos com oligonucleotídeo CS2 (401pb) foram: $R$. felis (CP000053), R.rickettsii cepa Sheila Smith (CP000848), cepa Brazil (NC016913), cepa Taiaçu (DQ115890), R. massiliae (CP003319), R. slovaca (CP002428), R. africae (CP001612), R. typhi (U59714), R. prowazekii (NC017560), e R. bellii (NC007940). O filodendograma obtido utilizando o método Neighbor-Joining está representado na Figuras 5.

Figura 5 - Filodendograma obtido através da comparação das sequências parciais do gene gltA (CS2 - 401pb), utilizando o método Neighbor-Joining

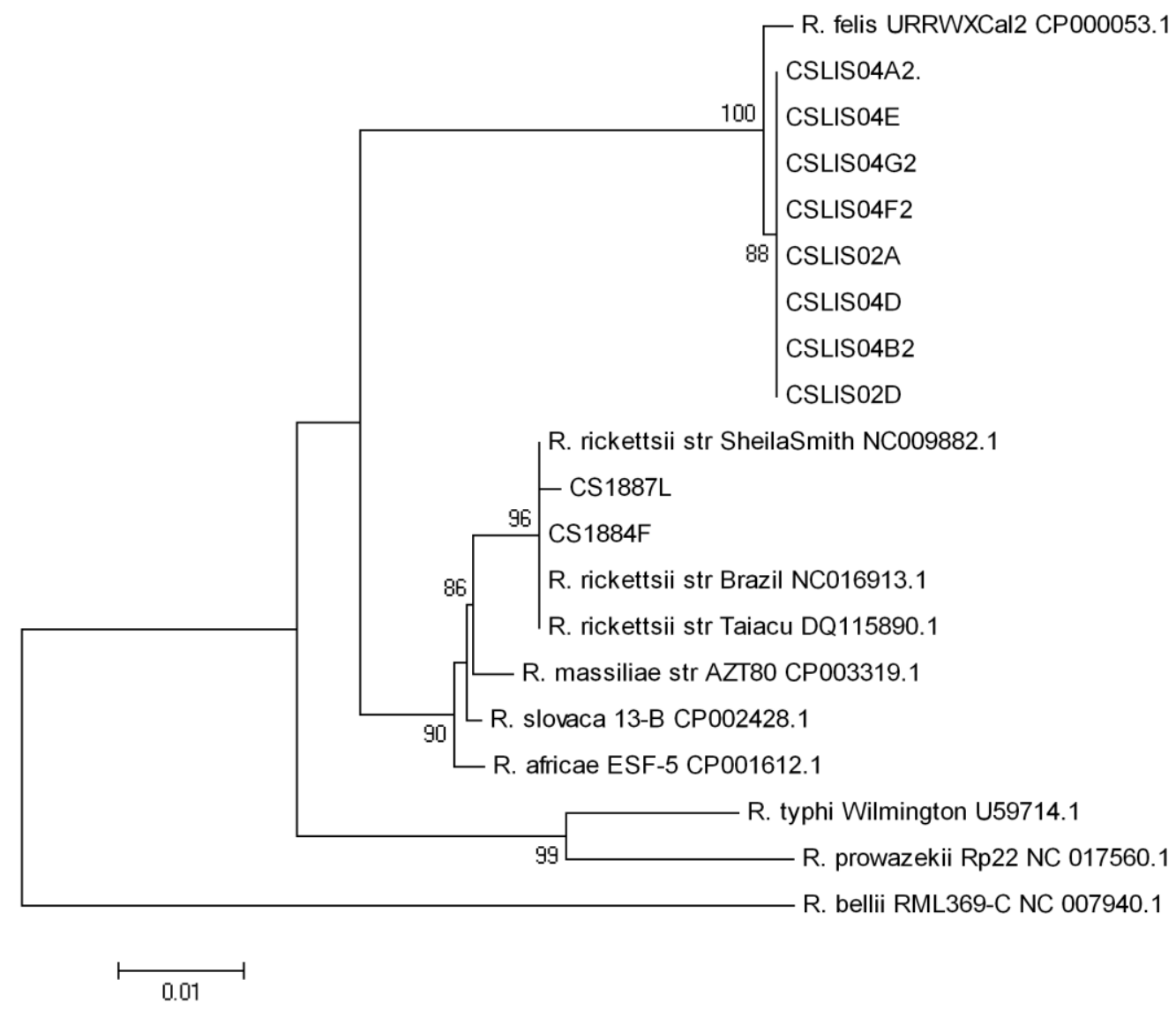

Os valores de bootstrap superiores a 70\% estão demonstrados.

As espécies de Rickettsia sp disponíveis no GenBank utilizadas para análise das sequências de fragmentos de gltA obtidos com oligonucleotídeo (CS4 - 834pb) de Rickettsia sp., foram: R. felis (CP000053), R.rickettsii cepa Sheila Smith (CP000848), cepa Brazil (NC016913), cepa Taiaçu (DQ115890), cepa Iowa (CP000766), cepa Hlp2 (CP003311), cepa 
Hauke (CP 003318), cepa Hino (CP003309), cepa Arizona (CP003307), cepa Colombia (CP003306), R. massiliae (CP003319), R. slovaca (CP002428), R. africae (CP001612), R. typhi (CP003398), R. prowazekii (DQ926862), R. bellii (CP000087), R. conorii (AE006914), R.honei (AF022817), R.sibirica (JX945526), R.parkeri (EF102236), R.japonica (AP011533), R.heilongjiangensis (CP002912), R.aeschlimannii (DQ235776), R.rhipicephali (DQ865206), R.australis (U59718), R.akari (CP000847), conforme Figura 6.

Figura 6 - Filodendograma obtido através da comparação das sequências parciais do gene gltA (CS4 - 834pb), utilizando o método Neighbor-Joining

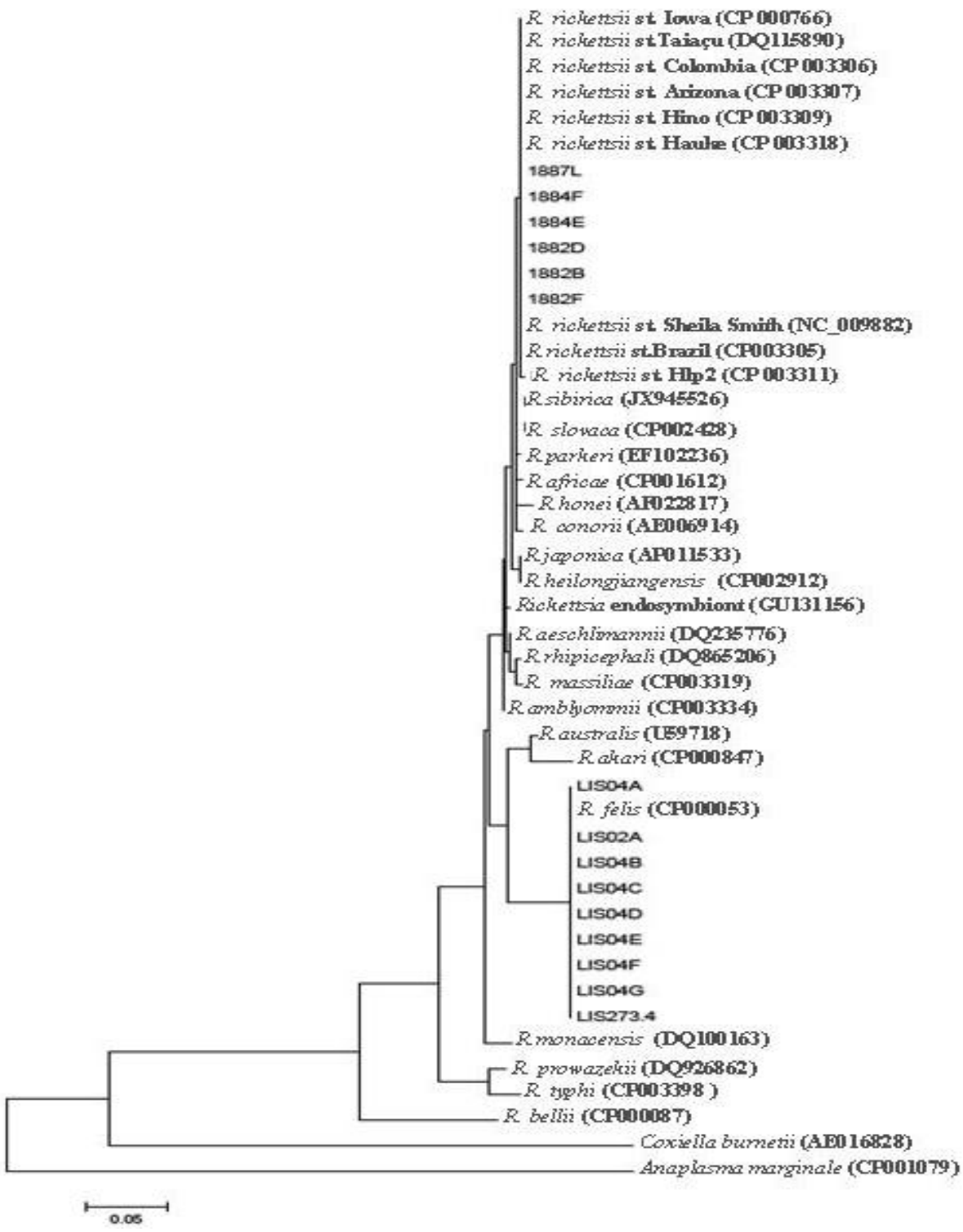

Os valores de bootstrap superiores a $70 \%$ estão demonstrados. 


\subsubsection{Análise de DNA microssatélite}

Nos ensaios de PCR realizados com gradiente de temperatura, para estabelecimento do protocolo, com foram utilizados: DNA genômico extraído de carrapatos Amblyomma aoreolatum infectados com $R$. rickettsii (amostra in vivo) e DNA genômico extraído de cultivo de células infectadas com $R$. rickettsii (amostra BME), gentilmente cedidas pela Dra. A. Fogaça - ICB - USP).

Entre as temperaturas de 46,1 e $52{ }^{\circ} \mathrm{C}$ verificou-se a amplificação do fragmento esperado (214pb); A temperatura de $52{ }^{\circ} \mathrm{C}$ mostrou-se mais adequada (Figura 7).

Figura 7 - Gradiente de temperatura para os oligonucleotídeos VNTRB em gel de agarose

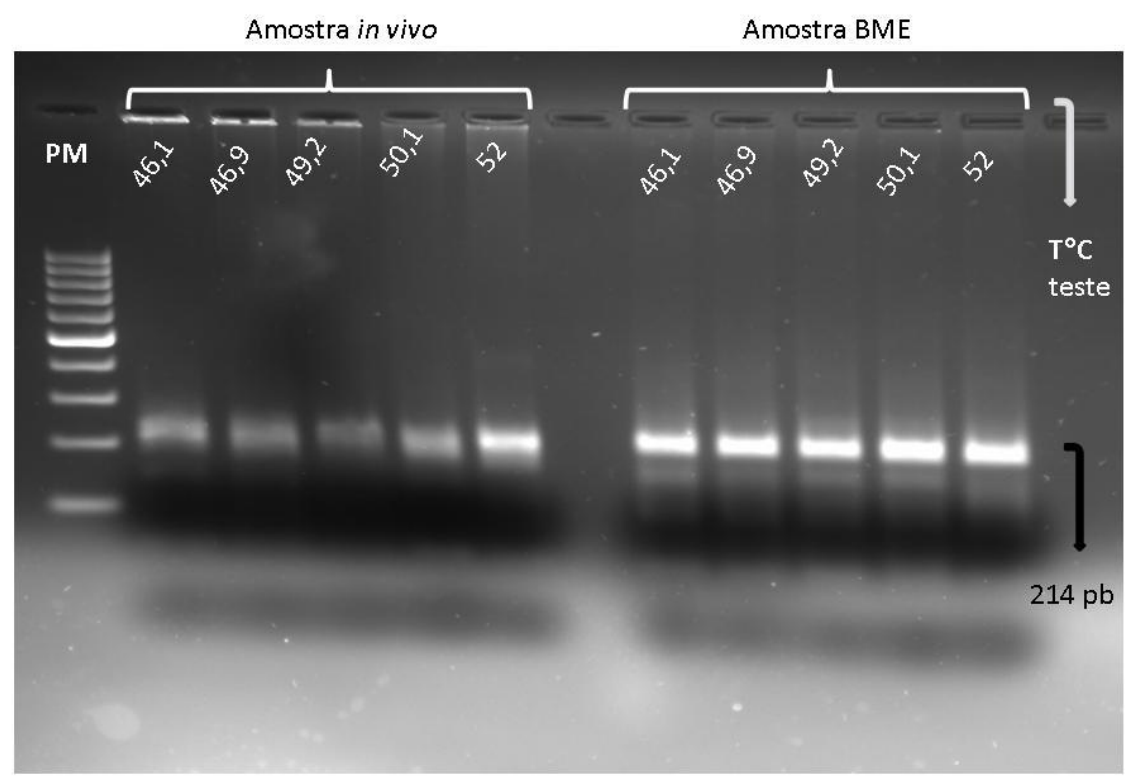

PM: marcador de peso molecular de 100pb; Amostra in vivo: DNAg extraído de carrapatos infectados com $R$. rickettsii; Amostra BME: DNAg extraído de cultivo celular infectado com $R$. rickettsii.

Nos ensaios com amostras de campo houve necessidade de variações da temperatura de anelamento para amplificação do fragmento.

De um total de 24 amostras de R.rickettsii analisadas, 15 apresentaram DNAg degradado (Figura 8). Nove amostras amplificaram o fragmento de gene esperado (Figura 9 e Tabela 9). 
Figura 8 - Gel de agarose da PCR para fragmento intergênico (VNTRB - 214pb) evidenciando degradação do DNA genômico das amostras

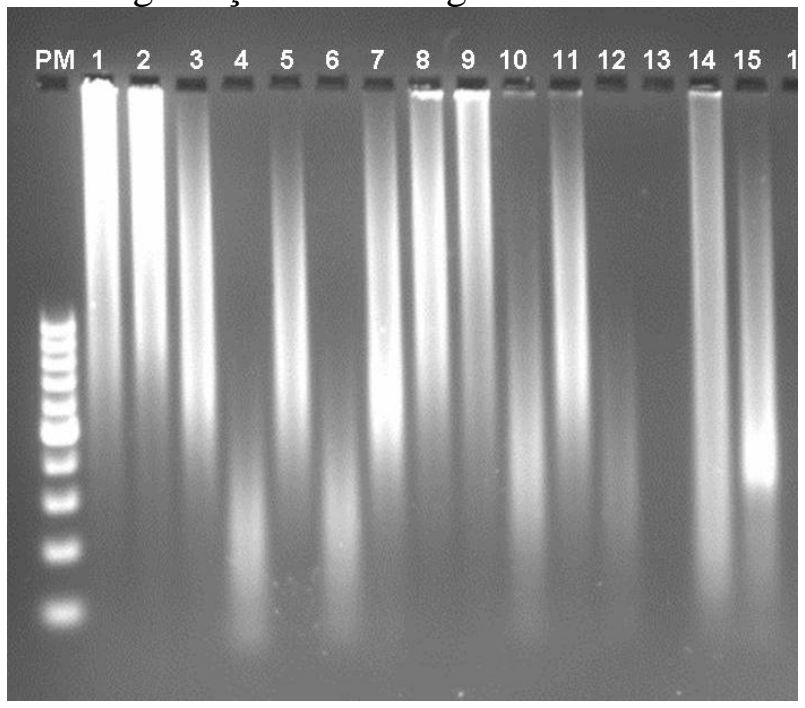

PM: peso molecular de 100pb; 1 a 15: amostras de DNAg degradadas.

Tabela 9 - Amostras de vetores utilizadas na pesquisa da região intergênica repetitiva

\begin{tabular}{llcc}
\multicolumn{1}{c}{ Amostras } & \multicolumn{1}{c}{ Espécie } & $\begin{array}{c}\text { Amplificação } \\
\text { VNTR }\end{array}$ & Sequenciamento \\
\hline 1882B & R.rickettsii & + & - \\
1882D & R.rickettsii & + & - \\
\hline 1882E & R.rickettsii & + & - \\
1882F & R.rickettsii & + & - \\
1884E & R.rickettsii & + & - \\
1884F & R.rickettsii & + & - \\
1887L & R.rickettsii & + & + \\
1956 & R.rickettsii & + & - \\
C + (BME) & R.rickettsii & + & + \\
LIS 02A & R.felis & - & - \\
LIS 02D & R.felis & - & - \\
LIS 04A & R.felis & - & - \\
LIS 04B & R.felis & - & - \\
LIS04D & R.felis & - & - \\
LIS 04E & R.felis & - & - \\
LIS 04F & R.felis & - & - \\
LIS 04G & R.felis & - & - \\
MGRrp & R.riphicephali & - & - \\
MGRpk & R.parkeri & - & - \\
RJRbel & R.belli & - & - \\
\hline
\end{tabular}

1956: $R$. rickettsii originária de A. cajenennse (GEHRKE,2010); MGRpk: $R$. parkeri e, MGRrp: $R$. riphicephali originárias de cultivo celular (Funed/SVR); RJRbel: R. belli originária de Amblyomma dubitatum (MOURA, 2012). 
Figura 9 - Gel de agarose da PCR para fragmento intergênico (VNTRB - 214pb)

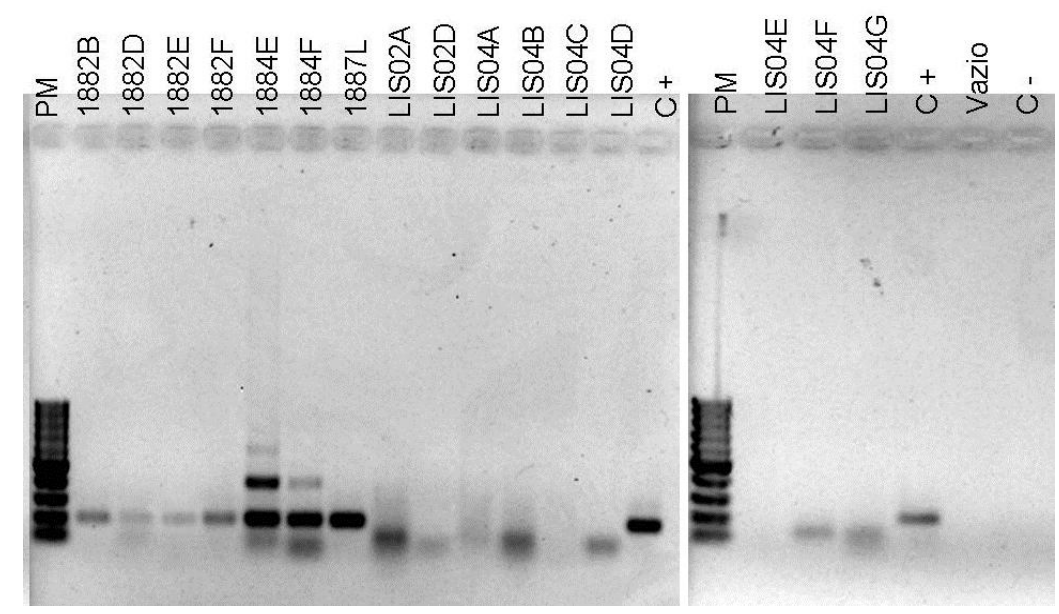

PM: peso molecular de 100pb, C+: controle positivo BME; C-: controle negativo (água); amostras: 1882B, 1882D, 1882E, 1882F, 1884E, 1884F, 1887L amplificação do VNTRB; amostras: LIS02A, LIS02D, LIS 04A, LIS04B, LIS04C, LIS 04D, LIS04E, LIS04F, LIS04G não amplificaram VNTRB

Amostras de Rickettsia parkeri, Rickettsia riphicepali, Rickettsia felis e Rickettsia belli não mostraram amplificação no gel de agarose (Figura 10).

Figura 10 - Gel de agarose da PCR para fragmento intergênico (VNTRB - 214pb) mostrando a ausência de amplificação

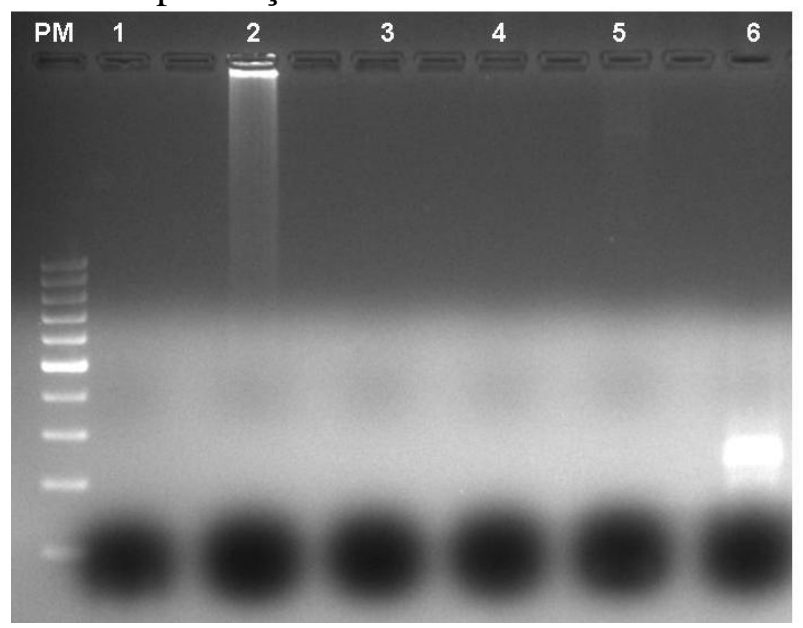

PM: peso molecular de 100pb; 1: Controle negativo (água); 2: R. riphicepali; 3: R. felis; 4: $R$. belli ; 5: $R$. parkeri; 6: controle positivo: BME.

\subsubsection{Análise de sequências}

As tentativas de clonagem do fragmento VNTR amplificado resultaram infrutíferas. As sequências da região intergênica repetitiva, tembém denominada "em tandem" - foram obtidas através do sequenciamento direto. A Figura 11 mostra o alinhamento da região VNTR (onde pode-se observar claramente o hexâmero GGTGGA em repetição) referente às amostras 
1887L e CTRL BME, cujas sequências foram obtidas no presente estudo, alinhadas à sequências de diferentes cepas depositadas no GenBank. Foram sequenciados 203 pb, englobando as três porções da região repetitiva já descritas na literatura (WIKSWO, 2007).

Figura 11 - Alinhamento das sequências obtidas da região intergênica com sequências depositadas no GenBank, com destaque para as repetições sequenciais

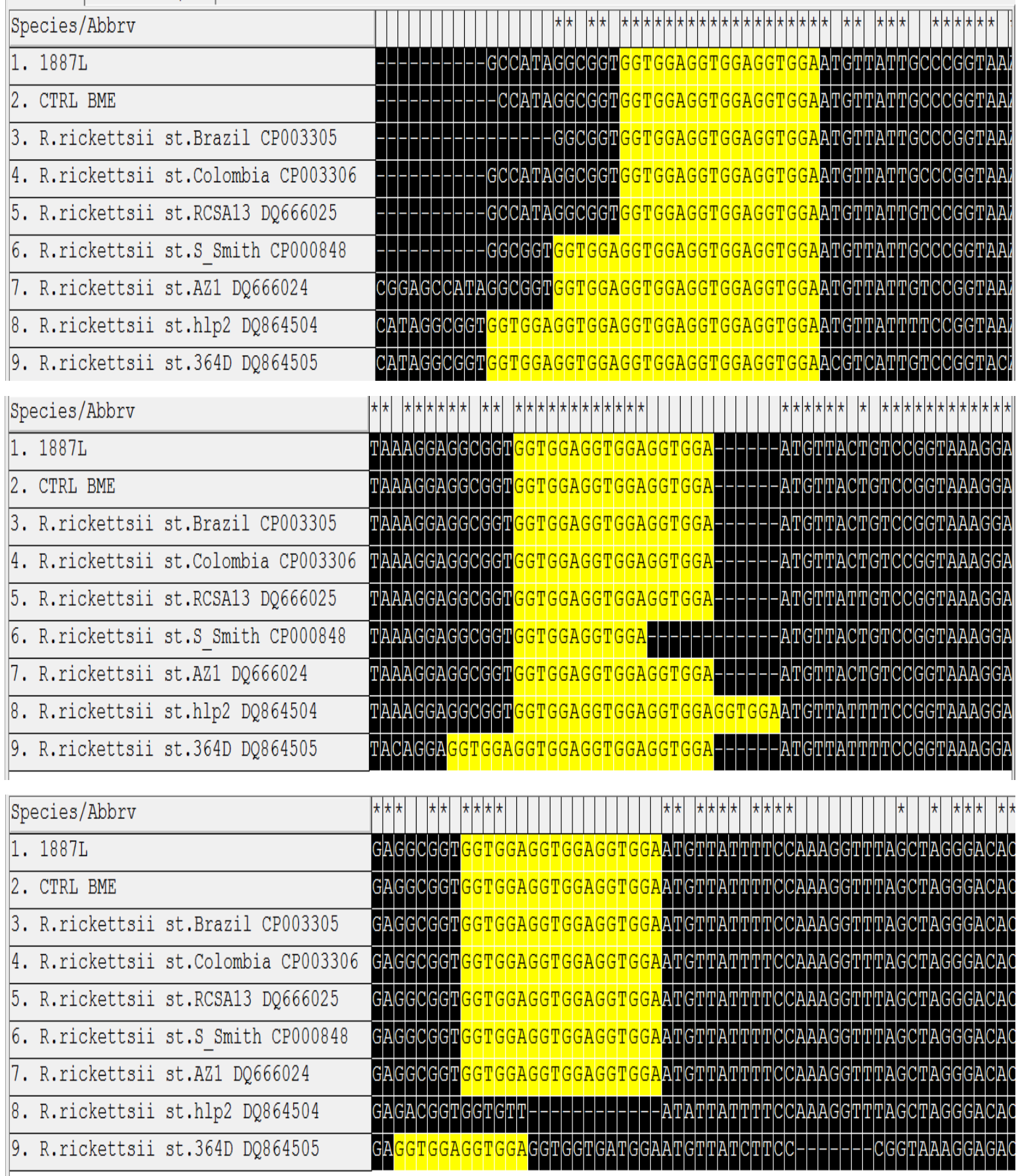

Species/Abbvr: espécies/abreviatura; 1: amostra 1887L, R. rickettsii originária de A. cajenennse; 2 CTRL BME: DNAg extraído de cultivo celular infectado com $R$. rickettsii; 3:R. rickettsii cepa Brazil (CP003305); 4:R. rickettsii cepa Colombia (CP003306); 5: $R$. rickettsii cepa RCSA13 (DQ666025); 6: $R$. rickettsii cepa Sheila Smith (CP000848); 7: R. rickettsii cepa AZ1 (DQ666024); 8: R. rickettsii cepa Hlp2 (DQ864504); 9: R. rickettsii cepa 364D (DQ864505); 


\section{DISCUSSÃO}

O estado do Rio de Janeiro tem condições ambientais particulares associadas aos focos endêmicos de FMB, podendo influenciar elementos epidemiológicos, ainda pouco estudados. A Mata Atlântica é um dos maiores biomas do Brasil, com ecossistemas que acompanham as características climáticas das regiões onde ocorrem. Está presente em todo o estado, englobando todas as regiões pesquisadas neste estudo. A ação antrópica tem influenciado intensamente na transformação desse bioma, com remanescentes florestais mantidos em unidades de conservação como o Maciço da Pedra Branca e Floresta da Tijuca - na região metropolitana; Reserva Biológica do Tinguá, que se estende da zona metropolitana até a Região Serrana; e Reserva Ecológica de Massambaba, na Região dos Lagos. A grande maioria dos casos de FMB está registrada na área desse bioma, que é também, associado a inúmeras áreas de turismo.

Neste contexto, pesquisas sorológicas e moleculares são importantes para evidenciar a circulação de riquétsias, contribuindo para o conhecimento epidemiológico da FMB no estado. A Reação de Imunofluorescência Indireta é um teste que possui metodologia relativamente simples, sensibilidade e especificidade acima de $90 \%$, e é considerada o método padrão-ouro de diagnóstico de riquetsioses pela Organização Mundial da Saúde (OPAS/OMS, 2004), detectando imunoglobulinas IgG e IgM. Os títulos mínimos padrão admitidos em situações clínicas são 1:64 (IgG) e 1:32 (IgM).

O kit do laboratório Füller utilizado neste estudo permite a detecção da classe de anticorpo IgG contra antígeno de $R$. rickettsii em soro ou plasma canino. Este anticorpo pode ser detectado cerca de uma semana após o início da doença, sendo específico dentro do grupo e podendo perdurar por até quatro anos. No presente estudo, a intensidade de fluorescência em títulos igual ou superior a 1:64 foi o limite usado para considerar amostras positivas para Rickettsia spp, como convencionado. Admite-se que a resposta humoral às infecções por diferentes riquétsias pode gerar reações cruzadas dentro do GFM (GALVÃO, 2005). Por esta razão, apesar do uso do antígeno espécie-específico, o protocolo estabelecido pelo LIRN considera também 1:512 o título limítrofe para detecção de riquétsias do GFM.

No presente estudo, foram analisadas amostras de soro canino, provenientes de seis municípios investigados do Estado do Rio de Janeiro. Em 14 amostras endpoint, ou último ponto de reatividade do soro foi a diluição de 1:1024. As altas soroconversões são uma evidência sorológica de infecção por riquétsias patogênicas do GFM. Constatou-se sorologia 
positiva em cães de todos os municípios, totalizando $68,0 \%$ das amostras com títulos iguais ou superiores a 1:64.

Os valores de prevalências de soropositivos obtidos em cães no presente trabalho são compatíveis com aqueles de áreas sabidamente endêmicas para Febre Maculosa Brasileira, em pesquisas com os mesmos critérios presentemente aplicados. Alta prevalência também foi encontrada em um estudo realizado por Gazêta et al. (2009) em municípios da região do Vale do Paraíba, estado do Rio de Janeiro, que detectou 58,7\% dos cães soropositivos para antígenos de Rickettsia ricketsii. Os autores destacaram a forte associação dos carrapatos Riphicephalus sanguineus e Amblyomma cajennense (principal vetor de FM incriminado no Brasil) aos cães naquela área. No presente estudo, Mangaratiba, município vizinho à região do Vale do Paraíba teve $70 \%$ de amostras reagentes.

No Estado de São Paulo, Pinter et al. (2008) encontraram 64\% e Moraes-Filho et al. (2009) encontraram 69,6\% de cães soro reativos ao antígeno de $R$. rickettsii. É interessante destacar que nestas áreas o principal carrapato associado à vetoração de riquétsias ao cão é o Amblyomma aureolatum (importante vetor de FM), diferente do que acontece para áreas estudadas no Rio de Janeiro. Já em Minas Gerais, o estudo de uma área endêmica revelou serem reativos $81,3 \%$ dos cães testados sorologicamente (VIANNA et al., 2008).

As altas prevalências podem indicar riscos de infecção humana por FMB. De acordo com Gazêta et al. (2009), os cães são importantes na manutenção do ciclo enzoótico peridomiciliar e, juntamente a equinos e seus ectoparasitas, são potencialmente responsáveis pelos eventos epizoóticos humanos observados na região do Vale do Paraíba. Experimentalmente os cães podem constituir fonte de infecção para os carrapatos, sendo considerados amplificadores de riquétsias (BURGDORFER, 1988).

O principal carrapato de cão, $R$. sanguineus, teve demonstrada experimentalmente sua capacidade de transmitir $R$. rickettsii de forma transestadial, e para animais de laboratório (PIRANDA, 2011). Na região metropolitana do Rio de Janeiro, já foi encontrado parasitando o ser humano, assim como o A. cajennense (SERRA-FREIRE; SENA; BORSOI, 2011). Também foi encontrado naturalmente infectado por $R$. rickettsii em áreas de ocorrência de casos de FMB no Rio de Janeiro (CUNHA, 2009; GEHRKE, 2010; MOURA, 2012). Embora ainda não esteja esclarecida sua competência como vetor em condições naturais, esses dados indicam a importância da investigação de cães e seus ectoparasitas em áreas endêmicas para FMB, pois a população canina nestas áreas está continuamente exposta aos carrapatos A.cajennense e/ou A.aureolatum, que são os principais vetores incriminados pela FMB em humanos no país (PIRANDA, 2011). 
Assim, alguns estudos têm correlacionado a presença de cães em peridomicílio, seus ectoparasitas e a ocorrência de riquétsias em uma determinada área, ressaltando o papel destes animais como sentinelas para áreas de ocorrência de riquetsioses (LABRUNA, 2007; PINTER, 2008), sendo importantes para o estabelecimento de prevalências geográficas de FM em uma região.

Em Japeri, Paraíba do Sul e Arraial do Cabo, a presente investigação constitui-se a primeira notificação da presença de anticorpos riquetsiais em cães. Neste sentido, é importante salientar que a maior prevalência dentre as regiões do estado foi verificada para a Região dos Lagos (município de Arraial do Cabo) onde 88,9\% das amostras coletadas apresentou título $\geq 1: 64$, demostrando pela primeira vez, a circulação de riquétsias na região. Isso ressalta a importância do cão como sentinela para riquetsioses e a necessidade de novas investigações epidemiológicas sobre o agente riquetsial naquela região. Destacamos que os caninos analisados no presente estudo eram originados de domicílio e peridomícilo humano.

A maior parte das amostras positivas foi coletada nos municípios de Mangaratiba, Japeri, Queimados e Rio de Janeiro, representando 55,81\% dos positivos e evidenciando a circulação de riquétsias nestes locais. Estes municípios pertencem à Região Metropolitana do estado do Rio de Janeiro, que é segunda maior área metropolitana do país, envolvendo uma alta densidade populacional e áreas de conservação de Mata Atlântica.

Além de sorologia, estudos moleculares, particularmente Nested PCR, têm sido usados para a detecção de genes riquetsiais em amostras de soro humanas (CHOI et al., 2005; LEITNER et al., 2002; NASCIMENTO et al., 2009). Para o estado do Rio de Janeiro, através PCR, foi confirmada a presença de genes riquetsiais gltA e ompA em amostras de DNA genômico extraído de soro de quatro cães e dois equinos de Barra do Piraí (GEHRKE, 2010). Angelakis et al. (2012), fazendo um interessante estudo comparativo entre PCR em Tempo Real, imunofluorescência e isolamento em cultura de células, para o diagnóstico de riquetsioses, concluíram que a cultura celular continua sendo crítica para determinação de cepas, mas é menos sensível que sorologia e PCR em Tempo Real para o diagnóstico de infecção por Rickettsia. Neste sentido, Moura (2012), trabalhando com amostras do Estado do Rio de Janeiro, observou um aumento de cerca de $10 \%$ na detecção de artrópodes positivos com o uso da PCR em Tempo Real, em relação à PCR convencional.

No presente estudo, embora a PCR dos soros não tenha apresentado resultados para os genes citados, as amostras foram testadas pela PCR em Tempo Real, obtendo amplificação do fragmento do gene riquetsial glt $\mathrm{A}$ em quatro amostras. Com isso, demonstrou-se pela primeira vez, Rickettsia spp. no soro de cães oriundos dos bairros da Gávea (Zona Sul), Vargem 
Grande (Zona Oeste) e Ilha do Governador (Zona Norte), no município do Rio de Janeiro; e Engenheiro Pedreira, no município Japeri. Com exceção do animal coletado na Ilha do Governador, os demais tiveram sorologia positiva, indicando a importância destes animais na cadeia epidemiológica de riquétsias na região Metropolitana do Rio de Janeiro. Esse achado também inclui o soro como importante material para investigação sobre a circulação dos agentes riquetsiais em determinado ecótopo. Além disso, a pesquisa de genes de riquétsias em soros torna-se interessante pois o soro é um dos principais materiais enviados para os laboratórios. Uma vez que o animal esteja no período da chamada janela imunológica, que é o tempo decorrido entre o contato do organismo com o agente infeccioso e a resposta imunológica ao mesmo, a detecção de anticorpos nem sempre é possível.

No estado do Rio de Janeiro, $R$. rickettsii foi encontrada infectando várias espécies de carrapatos (GEHRKE, 2010; MOURA, 2012). Entretanto, dados do Sistema de Informação de Agravos de Notificação (2011) sobre casos confirmados de FMB entre 1997 e 2011, mostram que o número de casos humanos no Rio de Janeiro (65 casos) é inferior aos verificados em outros estados da região sudeste como São Paulo (404 casos) e Minas Gerais (190 casos). Do ponto de vista epidemiológico, torna-se importante a investigação sobre a circulação de diferentes cepas desta espécie de riquétsia. Também é importante salientar que, devido aos sintomas inespecíficos, a doença pode muitas vezes ser subnotificada pelos órgãos de saúde. Acredita-se que exista uma maior tendência dos profissionais de saúde considerarem a Febre Maculosa como possível diagnóstico com mais frequência em áreas aonde já houve casos da doença.

No município de Petrópolis, em área de casos fatais de FMB, foram coletados 358 artrópodes pertencentes a diferentes gêneros e espécies: A. cajennense, Anocentor nitens, Rhipicephalus Boophilus microplus, R. sanguineus e Ctenocephalides felis, não diferindo das espécies encontradas por estudos anteriores (GEHRKE, 2010; MOURA, 2012). As maiores frequências absolutas encontradas para o número de vetores coletados foram para $A$. cajennense e $R$. sanguineus. De acordo com Moura (2012), o encontro de numerosos exemplares destas espécies nas áreas de estudo, parece ser comum para as regiões de foco de FMB no estado do Rio de Janeiro.

$R$. sanguineus está adaptado a ambiente antrópico em todo o Brasil, porém demonstra baixa antropofilia. É importante na manutenção do ciclo enzoótico de bioagentes entre canídeos, seus hospedeiros primários. No estado do Rio de Janeiro, R. sanguineus já foi encontrado infectado com $R$. rickettsii na região do Médio Paraíba (GEHRKE et al., 2009), além de terem sido relatados casos de parasitismo humano na área metropolitana (SERRA- 
FREIRE; SENA; BORSOI, 2011). Com relação ao A. cajennense, destaca-se o hábito alimentar eclético destes carrapatos, sua capacidade de transmissão de riquétsias para sua prole, comprovada experimentalmente, bem como o diagnóstico de $R$. rickettsii nestes carrapatos, realizado anteriormente para o Rio de Janeiro (GEHRKE, 2010; MOURA 2012), sugere que esta espécie possui papel importante no ciclo de riquétsias nos municípios presentemente investigados.

Os ectoparasitas foram coletados no ambiente ou sobre animais. Os potenciais vetores foram submetidos à pesquisa de genes riquetsiais. As amostras foram organizadas em 262 lotes, dos quais em 16 (6,10\%) houve amplificação do fragmento de gene pesquisado, demonstrando a presença de Rickettsia sp. circulante. Considerando a possibilidade da presença de riquétsias não patogênicas ou de patogenicidade desconhecida, a chance destas serem patogênicas é grande pois diversos estudos constatam a presença de $R$. rickettsii em vários municípios do Rio de Janeiro, inclusive no município de Petrópolis (GEHRKE, 2010; ROZENTAL et al., 2006; SOUZA, 2009; SOUZA et al., 2005).

$\mathrm{Na}$ análise das sequências do gene riquetsial glt $\mathrm{A}$, os fragmentos apresentaram entre 99\% e 100\% de identidade com Rickettsia felis ou $R$. rickettsii quando comparados a sequências disponibilizadas no GenBank. Diagnosticou-se Rickettsia felis em C. felis e R. rickettsii em A. cajennense indicando envolvimento deste carrapato no surto com casos fatais ocorrido no município de Petrópolis. Através da obtenção de sequências com valores de 99 e $100 \%$ de identidade com espécies do gênero Rickettsia, para os fragmentos do gene analisados, não há caracterização da espécie da bactéria encontrada, entretanto os dados constituem um indicativo potencial da presença da espécie de Rickettsia no artrópode.

A infecção de pulgas $C$. felis por $R$. rickettsii foi recentemente notificada em vetores em municípios do Rio de Janeiro (GEHRKE, 2010), mas o real valor epidemiológico deste tipo de inseto no ciclo da FMB merece ser mais bem investigado. A infecção por $R$. felis é mantida por transmissão transovariana, sem necessidade de um reservatório vertebrado, o que pode justificar a alta incidência dessas bactérias nesses vetores (WEDINCAMP; FOIL, 2002). Além disso, as infecções por $R$. felis não são letais para seus vetores naturais (AZAD et al., 1997), enquanto $R$. rickettsii em carrapatos, sim. (NIEBYLSKI et al., 1999).

Além de A. cajennense, mais duas espécies apontadas como vetoras da FMB. Uma delas é Amblyomma aureolatum da qual $R$. rickettsii foi isolada (LABRUNA, 2009; PINTER; LABRUNA, 2006). A outra, Amblyomma dubitatum, carrapato comumente encontrado parasitando capivaras, também tem sido apontado como possível vetor, embora isso ainda não tenha sido comprovado (SUCEN, 2012). Recentemente, em A. dubitatum, Moura (2012) 
registrou pela primeira vez presença de sequências com 99\% de identidade com Rickettsia bellii, para estado do Rio de Janeiro, e 100\% de identidade com $R$. rickettsii, para o Brasil e fez o primeiro relato da ocorrência deste patógeno para a região noroeste do estado. Há registros de detecção, através da PCR, de infecção de R. parkeri em Amblyomma triste, porém há poucos relatos de ocorrências de A. triste no Brasil; e ainda não se tem casos registrados de picada deste carrapato em seres humanos (SILVEIRA et al., 2007).

A. cajennense possui baixa especificidade parasitária, principalmente nos estágios iniciais, larva e ninfa, podendo parasitar inclusive o homem (ARAGÃO; FONSECA, 1953; SANGIONI, 2003). E em todos os estágios evolutivos, tanto a larva, a ninfa, quanto o adulto são capazes de transmitir Rickettsia sp. durante o repasto sanguíneo (COMER, 1991; SANGIONI, 2003).

Gazeta et al. (2009) destacaram A. cajennense como vetor de maior importância no ciclo epidêmico da FM em áreas do Vale do Paraíba, adjacentes as áreas abordadas no presente estudo. A infecção de A. cajennense por $R$. rickettsii remete ao que foi assinalado naquele estudo, que demonstrou a presença de riquétsias do Grupo Febre Maculosa em área de Floresta Tropical, reforçando a importância de um sistema de vigilância epidemiológica que possa detectar precocemente os potencias vetores da FMB e efetuar as medidas controle e prevenção necessárias, prevenindo os casos fatais humano, especialmente na região estudada, que abrange importantes áreas de turismo ecológico internacional.

O estudo de cepas para riquétsias vem sendo desenvolvido nos últimos anos. Em 2004, Fournier et al., investigando a determinação de possíveis cepas de $R$. conorii, encontraram repetições com variabilidade interindividual de comprimento num locus único, o que é designada por VNTRs "número variável de repetições sequenciais" (Variable Nucleotide Tandem Repeat), ou microssatélites, quando esses "blocos" de repetição (repetições em tandem) apresentam até 10 pares de base. O trabalho demonstrou que os espaços intergênicos variáveis são os mais adequados para estudos de genotipagem.

Existem ao menos 12 regiões repetitivas no genoma de $R$. rickettsii, mas poucas delas mostraram-se variáveis. Neste sentido, Eremeeva et al. (2006) analisaram VNTRs, em amostras de R.rickettsii de carrapatos e humanos de diferentes regiões dos EUA (Arizona e Montana), constatando, através de sequenciamento, que dois, dos 12 loci de VNTR, continham diferentes números de sequências repetitivas. Um destes recebeu a denominação de Região Intergênica VNTRB (que também designou o iniciador para a sua amplificação), e situa-se entre os nucleotídeos 845704 e 845898 do genoma, tomando por base a sequência da cepa Sheila Smith, depositada no GenBank sob o número de acesso: CP000848 
(EREMEEVA, 2006; WIKSWO, 2007). O estudo demonstrou a diferença entre isolados de Montana e do Arizona, não estabelecendo, porém, um grau de associação geográfica. Em 2007, Wikswo e colaboradores examinaram, também para a região intergênica $\mathrm{B}$ de $R$. rickettsii, amostras desta bactéria oriundas de carrapatos e humanos, provenientes de diferentes estados, e as sequências geradas foram comparadas com uma já depositada no GenBank, sob o número de acesso DQ666025, da cepa RCSA. Diferentes padrões de repetição de $R$. rickettsii puderam ser encontrados entre as riquétsias provenientes de Arizona, Montana e Califórnia, o que levou à sugestão de uma diversidade genética das diferentes amostras do GFM analisadas, e demonstrando correlação com a distribuição geográfica das cepas. Também foi observado que um sorotipo da Califórnia, isolado de Rhipicephalus sanguineus, reconhecidamente patogênico, diferiu de outra cepa, 364D, também da Califórnia (isolada de Dermacentor occidentalis) e de Hlp2 (isolada de Haemaphysalis leporispalustris), que são comumente consideradas apatogênicas. A diferença na região VNTR ficou demonstrada entre elas.

Na presente pesquisa, a análise para VNTR foi delineada inicialmente com amostras previamente identificadas por sequências de genes riquetsiais como $R$. rickettsii, em estudo anterior (GEHRKE, 2010), e de R.rickettsii sequenciadas a partir de amostras de vetores do município de Petrópolis, Rio de Janeiro, presentemente diagnosticadas.

Das 9 amostras nas quais foi possível verificar a amplificação no gel de agarose, apesar de sucessivas tentativas, não foi possível a clonagem do fragmento. No sequenciamento direto, duas apresentaram qualidade suficiente no sequenciamento, cobrindo toda a região que engloba as repetições em tandem. No alinhamento com as sequências geradas pelos estudos de Eremeeva et al. (2006) e Wiskwo et al. (2007), encontramos resultados diferentes daqueles descritos anteriormente. Apesar de o número de repetições sequenciais variar, não fica clara uma separação geográfica entre as amostras latinas e as norte americanas. O padrão de repetição das amostra 1887L, BME, cepa Brazil, Colômbia e cepa RCSA13 foi idêntico, sendo que a última é de um isolado Californiano. A amostra 1887L é de A. cajennense de Petrópolis, Rio de Janeiro, enquanto a BME é de cultivo celular de $R$. rickettsii isolada de A. aureolatum, em Mogi das Cruzes, São Paulo. Já a cepa Sheila Smith, de Montana, mostrou um padrão diferente de todas as demais. Este dado também foi encontrado por Estripeaut e colaboradores (2007). Eles compararm cepas do Brasil, Colômbia, Panamá e Costa Rica, em uma outra região repetitiva do genoma, e observaram a também uma diferença no padrão repetitivo apresentado pela cepa Montana. 
Dados os resultados do presente experimento, não é conclusivo o uso dos iniciadores (VNTRB) para a região intergênica $\mathrm{B}$ com o objetivo de genotipagem de cepas de $R$. rickettsii. No entanto, é perceptível que a $R$. rickettsii que circula no Panamá (ESTRIPEAUT, et al, 2007), assim como no Sudeste do Brasil, presentemente analisada, é similar a outras cepas que circulam na América do Sul, mas difere da cepa Sheila Smith em dois locus de regiões repetitivas.

Por outro lado, observamos a amplificação da região VNTR pesquisada em diferentes amostras de $R$. rickettsii, o que não foi observado em amostras de $R$. felis, Rickettsia parkeri, Rickettsia rhipicephali ou Rickettsia bellii, sugerindo espécie-especificidade dos iniciadores utilizados. A análise de um maior número de amostras poderá confirmar a utilização da região intergênica B como marcador específico. 


\section{CONCLUSÃO}

Sob as condições desenvolvidas no presente trabalho, as investigações sorológicas e moleculares realizadas com amostras biológicas procedentes de áreas sem casos, com casos suspeitos ou confirmados de Febre Maculosa, do estado do Rio de Janeiro, possibilitaram:

- detectar, pela primeira vez, anticorpos IgG contra riquétsias Grupo Febre Maculosa nos soros de cães procedentes dos municípios Rio de Janeiro, Japeri, Arraial do Cabo e Paraíba do Sul, estado do Rio de Janeiro;

- demonstrar pela primeira vez Rickettsia sp. no soro de cães oriundos dos bairros da Gávea, Ilha do Governador e Vargem Grande (município do Rio de Janeiro) e Engenheiro Pedreira (município Japeri) indicando a importância destes animais na cadeia epidemiológica de riquétsias na região Metropolitana do Rio de Janeiro;

- diagnosticar sequências com 99 e 100\% de identidade com Rickettsia rickettsii em Amblyomma cajennense e, ainda, sequências com 99 e $100 \%$ de identidade com Rickettsia felis em pulgas Ctenocephalides felis, coletads no município de Petrópolis/RJ;

- amplificar a região VNTR pesquisada em diferentes amostras de Rickettsia rickettsii, o mesmo não se verificando em amostras de $R$. felis, $R$. parkeri, $R$. rhipicephali (GFM) ou R. bellii (GA), sugerindo espécie-especificidade dos iniciadores (VNTRB) utilizados;

- apontar a limitação do uso dos iniciadores (VNTRB) para a região VNTR na diferenciação genotípica de cepas de $R$. rickettsii presentemente analisadas, oriundas de diferentes regiões geográficas. 


\section{REFERÊNCIAS*}

ALJANABI, S. M.; MARTINEZ, I. Universal and rapid salt extraction of high genomic DNA for PCR-based techniques. Nucleic. Acid. Res., v. 25, n. 22, p. 4692-4693, 1997.

ANGELAKIS, E.; RICHET, H.; ROLAIN, J-M.; LA SCOLA, B.; RAOULT, D. Comparison of Real-Time Quantitative PCR and Culture for the Diagnosis of Emerging Rickettsioses. Plos. Negl. Trop. Dis., v. 6, n. 3, 2012.

ARAGÃO, H. B.; FONSECA, F. Notas de Ixodologia: propósito da validade de algumas espécies do gênero Amblyomma do continente Americano (Acari:Ixodidae). Memórias do Instituto Oswaldo Cruz, n. 51, p. 485-492, 1953.

AZAD, A. F.; BEARD, C. B. Rickettsial pathogens and their arthropod vectors. Emer. Infect. Dis., v. 4, n. 2, p. 179-186, 1998.

AZAD, A. F.; RADUlOVIC, S.; HIGGINS, J. A.; NODEN, B. H.; TROYER, J. M. Fleaborne rickettsioses: ecologic considerations. Emerg. Infect. Dis., v.3, n.3, p. 319-327. 1997.

AZAD, A. F.; WEBB, L.; CARL, M.; DASCH, G. A. Detection of Rickettsiae in arthropod vectors by DNA amplification using the polymerase chain reaction. Ann. N. Y. Acad., v. 590, p. 557-563, 1990.

BRASIL. Ministério Da Saúde. Febre Maculosa. Casos confirmados notificados no Sistema de Informação de Agravos de Notificação - SINAN. 2010. Disponível em: <http://dtr2004.saude.gov.br/sinanweb/index.php>. Acesso em: 12 fev. 2013.

BROUQUI, P.; BACELLAR, F.; BARANTON, G.; BIRTLES, R. J.; BJOERSDORFF, A.; BLANCO, J. R.; CARUSO, G.; CINCO, M.; FOURNIER, P. E.; FRANCAVILLA, E.; JENSENIUS, M.; KAZAR, J.; LAFERL, H.; LAKOS, A.; LOTRIC-FURLAN, S.; MAURIN, M.; OTEO, J. A.; PAROLA, P.; PEREZ-EID, C.; PETER, O.; POSTIC, D.; RAOULT, D.; TELLEZ, A.; TSELENTIS, Y.; WILSKE, B. Guideline for the diagnosis of tick-borne bacterial diseases in Europe. Clin. Microbiol. Infect., v. 10, n. 12, p. 1108-1132, 2004.

BURGDORFER, W. Ecological and epidemiological considerations of Rock Mountains spotted fever and scrub typhus. In: WALKER, D. H. Biology of rickettsial diseases, Boca Raton: Editora CRC, p. 33-50. 1988.

CARDOSO, L. D.; FREITAS, R. N.; MAFRA, C. L.; NEVES, C. V. B.; FIGUEIRA, F. C. B.; LABRUNA, M. B.; GENNARI, S. M.; WALKER, D. H.; GALVÃO, M. A. M. Caracterização de Rickettsia spp. circulante em foco silencioso de febre maculosa brasileira no Município de Caratinga, Minas Gerais, Brasil. Cad. Saúde Pública, v. 22, n. 3, p. 495501, 2006.

\footnotetext{
* De acordo com: ASSOCIAÇÃO BRASILEIRA DE NORMAS TÉCNICAS. NBR 6023: Informação e documentação: referências: elaboração. Rio de Janeiro, 2002.
} 
CENTERS FOR DISEASE CONTROL AND PREVENTION -CDC. Diagnosis and Management of Tickborne Rickettsial Diseases: Rocky Mountain Spotted Fever, Ehrlichioses, and Anaplasmosis - United States; a practical guide for physicians and other health-care and public health professionals. Morbidity and Mortality Weekly Report, CDC, Atlanta, GA. v.55, n.RR-4, 36p, 2006.

CHEN, L. F.; SEXTON, D. J. What's new in Rocky Mountain spotted fever? Infectious Disease Clinics of North America, v. 22, p. 415-32, 2008.

CHOI, Y. J.; LEE, S. H.; PARK, K. H.; KOH, Y. S.; LEE, K. H.; BAIK, H. S.; CHOI, M. S.; KIM, I. S.; JANG, W. J. Evaluation of polymerase chain reaction-based diagnosis of spotted fever group rickettsiosis in human serum samples. Clin. Diagn. Lab. Immunol., v. 12, p. 759-76, 2005.

COMER, M. K. Rocky mountain spotted fever. Veterinary Clinics of North America. Small Animal Practice, v.21, n. 1, p. 27-44, 1991.

CUNHA, N. C.; FONSECA, A. H.; REZENDE, J.; ROZENTAL, T.; FAVACHO, A. R. M.; BARREIRA, J. D.; MASSARD, C. L.; LEMOS, E. R. S.; First identification of natural infection of Rickettsia rickettsii in the Rhipicephalus sanguineus tick, in the state of Rio de Janeiro. Pesquisa Veterinária Brasileira, v. 29, n. 2, p. 105-108, 2009.

DEAN, F. B.; HOSONO, S.; FANG, L.; WU, X.; FARUGI, A. F.; BRAY-WARD, P.; SUN, Z.; ZONG, Q.; DU, Y.; DU, J.; DRISCOLL, M.; SONG, W.; KINGSMORE, S. F.; EGHOLM, M.; LASKEN, R. S. Comprehensive human genome amplication using multiple displacement amplification. Proc. Natl. Acad. Sci. U. S. A., v. 99, p. 5261-5266, 2002.

DEMMA, L. J.; TRAEGER, M. S.; NICHOLSON, W. L.; PADDOCK, C. D.; BLAU, D. M.; EREMEEVA, M. E.; DASCH, G. A.; LEVIN, M. L.; SINGLETON, J. JR.; ZAKI, S. R.; CHEEK, J. E.; SWERDOLOW, D. L.; McQUISTON, J. H. Rock Mountain Spotted Fever from Arizona an Unexpected Tick Vector in Arizona. The New England Journal of Medicine, v. 353, n.6, p. 587-594, 2005.

DIAS, E.; MARTINS, A. V. Spotted fever in Brazil. Am. J. Trop. Med. Hyg., v. 19, n. 2, p. 103-108, 1939. Disponível no site: 〈http://www.sucen.sp.gov.br>

EREMEEVA, M. E.; BOSSERMAN, E.; ZAMBRANO, M.; DEMMA, L.; DASCH, G. A. Molecular typing of novel Rickettsia rickettsii isolates from Arizona. Ann. N. Y. Acad., v. 1078, p. 573-577, 2006.

EREMEEVA, M. E.; DASCH, G. A. Rickettsiae. In. LEDERBERG, J. Encyclopedia of microbiology, New York: Academic Press, v. 4, p. 140-180, 2000.

ESTRIPEAUT, D.; ARAMBURÚ, M. G.; SAÉZ-LLORENZ，X.; THOMPSON， H.A.; DASH, G. A.; PADDOCK, C.D.; ZAKI, S.; EREMEEVA, M. E. Rocky Mountain Sppoted Fever, Panamá. Emerging Infectius Diseases. v. 13, n. 11, p. 1763-1765, 2007.

FOURNIER, P. E.; RAOULT, D. Bacteriology, taxonomy and phylogeny of Rickettsia. In RAOULT, D.; PAROLA, P. Rickettsial Dieseases. New York, London. Editora Informa Health Care, cap. 1, p. 1-13, 2009. 
FOURNIER, P. E.; ZHU, Y.; OGATA, H.; RAOULT, D. Use of highly variable intergenic spacer sequences for multispacer typing of Rickettsia conorii strains. J. Clin. Microbiol., v. 42, p. 5757-5766, 2004.

GALVÃO, M. A. M.; SILVA, L. J.; NASCIMENTO, E. M. M.; CALIC, S. B.; SOUSA, R.; BACELLAR, F. Riquetsioses no Brasil e Portugal: ocorrência, distribuição e diagnóstico. Rev. Saúde Pública, v. 39, p. 850-856, 2005.

GALVÃO, M. A.; MAFRA, C.; CHAMONE, C. B.; CALIC, S. B.; ZAVALAVELAZQUEZ, J. E.; WALKER, D. H. Clinical and laboratorial evidence of Rickettsia felis infections in Latin America. Rev. Soc. Bras. Med. Trop., v. 3, p. 238-240, 2004. Suppl. 37.

GAZÊTA, G. S.; SOUZA, E. R.; ABBOUD-DUTRA, A. E.; AMORIM, M.; BARBOSA, P. R.; ALMEIDA, A. B.; GOMES, V.; GEHRKE, F. S.; MARRELLI, M. T.; SCHUMAKER, T. T. S. Potential vectors and hosts of Rickettsia spp: epidemilogical studies in the Vale do Paraíba, state of Rio de Janeiro/Brazil. Clin. Microbiol. Infect., v. 15, n. 2, p. 269-270, 2009.

GEHRKE, F. S. Detecção e caracterização molecular de riquétsias em humanos, potenciais vetores e animais domésticos da região sudeste do Brasil. 2010. $100 \mathrm{f}$. Tese (Doutorado em Parasitologia) - Instituto de Ciências Biomédicas, Universidade de São Paulo, São Paulo, 2010.

GEHRKE, F. S.; GAZETA, G. S.; SOUZA, E. R.; RIBEIRO, A.; MARRELLI, M. T.; SCHUMAKER, T. T. S. Rickettsia rickettsii, Rickettsia felis and, Rickettsia sp. TwKM03 infecting Rhipicephalus sanguineus and Ctenocephalides felis collected from dogs in a Brazilian Spotted Fever focus in the state of Rio de Janeiro/Brazil. Clin. Microbiol. Infect Dis., v. 15, n. 2, p. 267-268, 2009.

GUEDES, E.; LEITE, R. C.; PRATA, M. C. A.; PACHECO, R. C.; WALKER, D. H.; LABRUNA, M. B. Detection of Rickettsia rickettsii in the tick Amblyomma cajennense in a new Brazilian spotted fever-endemic area in the state of Minas Gerais. Mem. Inst. Oswaldo Cruz., v. 100, n. 8, p. 841-845, 2005.

HALL, T. A. BioEdit: a user friendly biological sequence alignment editor and análisis program for Windows 95/98/NT. Nucl. Acids. Symp n.41p. 95-98 1999.

HORTA, M. C.; CHIEBAO, D. P.; DE SOUZA, D. B.; FERREIRA, F.; PINHEIRO, S. R.; LABRUNA, M. B.; SCHUMAKER, T. T. Prevalence of Rickettsia felis in the Fleas Ctenocephalides felis felis and Ctenocephalides canis from Two Indian Villages in São Paulo Municipality, Brazil. Ann. N. Y. Acad. Sci., v. 1078, p. 361-363, 2006.

LA SCOLA, B.; RAOULT, D. Laboratory diagnosis of rickettsioses: current approaches to diagnosis of old and new rickettsial diseases. Journal of Clinical Microbiology, v. 35, n. 11, p. 2715-2727, 1997.

LABRUNA, M. B. Ecology of Rickettsia in South America. Ann. N. Y. Acad. Sci, v. 11, p. 156-66, 2009. 
LABRUNA, M. B. Epidemiologia da Febre Maculosa no Brasil e nas Américas. In: SIMPÓSIO BRASILEIRO DE ACAROLOGIA, 1., 2006, Viçosa, MG. Livro de resumos... Viçosa, MG: Universidade Federal de Viçosa, 2006. p. 63-78.

LABRUNA, M. B.; HORTA. M. C.; AGUIAR, D. M. CAVALCANTE, G. T.; PINTER, A.; GENNARI, S. M.; CAMARGO, L. M. A. Prevalence of Rickettsia infection in dogs from the urban and rural areas of Monte Negro municipality, western Amazon, Brazil. Vector-Borne and Zoonotic Diseases, v.7, p.249-255, 2007.

LABRUNA, M. B.; MCBRIDE, J. W.; BOUYER, D. H.; CAMARGO, L. M. A.; CAMARGO, E. P.; WALKER, D. H. Molecular evidence for a spotted fever group Rickettsia species in the tick Amblyomma longirostre in Brazil. J. Med. Entomol., v. 41, p. 533-537, 2004a.

LABRUNA, M. B.; WHITWORTH, T.; HORTA, M. C.; BOUYER, D. H.; MCBRIDE, J. W.; PINTER, A.; POPOV, V.; GENNARI, S. M.; WALKER, D. H. Rickettsia species infecting Amblyomma cooperi ticks from an area in the state of São Paulo, Brazil, where Brazilian spotted fever is endemic. J. Clin. Microbiol., v. 42, p. 90-98, 2004b.

LAMAS, C.; FAVACHO, A.; ROZENTAL, T.; BÓIA, M. N.; KIRSTEN, A. H.; GUTERRES, A.; BARREIRA, J.; LEMOS, E. R. S. Characterization of Rickettsia rickettsii in a case of fatal Brazilian spotted fever in the city of Rio de Janeiro, Brazil. Braz. J. Infect. Dis., v. 2, p. 149-151, 2008. Suppl. 12.

LEITNER, M.; YITZHAKI, S.; RZOTKIEWICZ, S.; KEYSARI, A.; Polymerase chain reaction-based diagnosis of Mediterranean spotted fever in serum and tissue samples. Am. J. Trop. Med., v. 67, p. 166-169, 2002.

LEMOS, E. R. S. Rickettsioses: breves considerações Boletim Sierj. n. 41, p. 3-4, 2012.

LEMOS, E. R. S.; ROZENTAL, T.; VILLELA, C. L. Brazilian spotted fever: description of a fatal clinical case in the State of Rio de Janeiro. Rev. Soc. Bras. Med. Trop., v. 35, p. 52325, 2002. Suppl. 5.

MELLES, B. H. H.; COLOMBO, S.; LEMOS, E. R. S. Isolamento de Rickettsia em cultura de células. Rev. Soc. Bras. Med. Trop., v. 32, p. 69-73, 1999.

MORAES-FILHO, J.; HORTA, M. C.; PACHECO, R. C.; MAEDA, M. M.; GALANO, A.; OLIVEIRA, M. L.; YAI, L. E. O.; LABRUNA, M. B. Pesquisa de anticorpos anti-Rickettsia rickettsii em equinos do Centro de Controle de Zoonoses do município de São Paulo (CCZ/SP). Braz. J. Vet. Res. Anim. Sci., São Paulo, v. 46, n. 2, 2009a.

MORAES-FILHO, J.; PINTER, A.; PACHECO, R. C.; GUTMANN, T. B.; BARBOSA, S. O.; GONZÁlEZ, M. A. R. M.; MURARO, M. A.; CECÍlIO, S. R. M.; LABRUNA, M. B. New epidemiological data on Brazilian spotted fever in an endemic area of the state of São Paulo, Brazil. Vector-Borne and Zoonotic Diseases, v. 9, p. 73-78, 2009 b. 
MOURA, N. O. Detecção e caracterização molecular de riquétsias em potenciais vetores procedentes de focos ativos de febre maculosa do estado do Rio de Janeiro. 2012. $78 \mathrm{f}$. Mestrado (Dissertação em Biologia da Relação Patógeno-Hospedeiro) - Instituto de Ciências Biomédicas, Universidade de São Paulo, São Paulo, 2012.

NACIONAL CENTER FOR BIOTECHNOLOGY INFORMATION. BLAST Assembled RefSeq Genomes. Nucleotide Blast. Disponível em: 〈http://www.ncbi.nlm.nih.gov>. Acesso em: 15 mar. 2013.

NASCIMENTO, E. M. M. Isolamento e detecção molecular de riquétsias do Grupo Febre Maculosa, a partir de Amblyomma cajennense (Fabricius, 1787) e espécimes biológicos humanos, provenientes de áreas endêmicas do Estado de São Paulo. 2003. 70 f. Dissertação (Mestrado em Ciências) - Instituto de Ciências Biomédicas, Universidade de São Paulo, São Paulo. 2003.

NASCIMENTO, E. M. M.; COLOMBO, S.; NAGASSE-SUGAHARA, T.K.; ANGERAMI, R. N.; RESENDE, M. R; DA SILVA, L. J.; KATZ, G.; DOS SANTOS, F. C. Evaluation of PCR-based assay in human serum samples for diagnosis of fatal cases of spotted fever group rickettsiosis. Clin. Microbiol. Infect., v. 15, p. 232-234, 2009.

NIEBYLSKI, M. L.; PEACOCK, M. G.; SCHWAN, T. G. Lethal effect of Rickettsia rickettsii on its tick vector (Dermacentor andersoni). Appl. Environ. Microbiol., v. 65, n. 2, p. 773-778. 1999.

OLIVEIRA, K. A.; OLIVEIRA, L. S.; DIAS, C. C. A.; SILVA, JR., A.; ALMEIDA, M. R.; ALMADA, G.; BOUYER, D. H.; GALVÃO, M. A. M.; MAFRA, C. L. Molecular identification of Rickettsia felis in ticks and flea from an endemic area for brazilian spotted fever. Mem. Inst. Oswaldo Cruz, v. 103, n. 2, p. 191-194, 2008.

OLIVEIRA, P. R. Amblyomma cajennense (Fabricius, 1787) (Acari: Ixodidae): Avaliação de técnicas para o estudo de dinâmica populacional e biotecnologia. 1998. 91 f. Doutorado (Tese) . Universidade Federal de Minas Gerais, Belo Horizonte (Brasil), 1998.

ORGANIZAÇÃO PAN-AMERICANA DE SAÚDE (OPAS/OMS). Consulta de especialistas sobre rickettsioses nas Américas. Ouro Preto, MG, Brasil. 2004. 52 p.

PACHECO, R. C.; HORTA, M. C.; MORAES-FILHO, J;.ATALIBA, A. C.; PINTER, A.; LABRUNA, M. B. Rickettsial infection in capybaras (Hydrochoerus hydrochaeris) from São Paulo, Brazil: serological evidence for infection by Rickettsia bellii and Rickettsia parkeri. Biomedica, n. 27, p.364-71, 2007.

PADDOCK, C. D.; GREER, P. W.; FEREBEE, T. L.; SINGLETON, J. J.R.; MCKECHNIE, D. B.; TREADWELL, T. A.; KREBS, J. W.; CLARKE, M. J.; HOLMAN, R. C.; OLSON, J. G.; CHILDS, J. E.; ZAKI, S. R. Hidden mortality attributable to Rocky Mountain spotted fever: immunohistochemical detection of fatal, serologically unconfirmed disease. J. Infect. Dis., v. 179, p. 1469-1476, 1999. Suppl. 6. 
PADDOCK, C. D.; SUMNER, J. W.; COMER, J. A.; ZAKI, S. R.; GOLSMITH, C. S.; GODDARD, J.; MCLELLAN, S. L. F.; TAMMINGA, C. L.; OHL, C. A. Rickettsia parkeri: A newly reconized cause of spotted fever rickettsiosis in the United States. Clin. Infect. Dis., v. 38, n. 6, p. 805-811, 2004.

PAROLA, P.; DAVOUST, B.; RAOULT, D. Tick- and flea-borne rickettsial emerging zoonoses. Vet. Res., v. 36, n. 3, p. 469-492, 2005.

PAROLA, P.; RAOULT, D. Tick and tickborne bacterial diseases in humans: an infectious threat. Clin. Inf. Dis., v. 32, p. 897-928, 2001.

PINTER, A.; HORTA, M. C.; PACHECO, R. C.; MORAES-FILHO, J.; LABRUNA, M. B. Serosurvey of Rickettsia spp. in dogs and humans from an endemic area for Brazilian spotted fever in the State of São Paulo. Cadernos de Saúde Pública, v. 24, n. 2, p. 247-252, 2008.

PINTER, A.; LABRUNA, M. B. Isolation of Rickettsia rickettsii and Rickettsia bellii in cell culture from the tick Amblyomma aureolatum in Brazil. Ann. N. Y. Acad. Sci., v. 1078, p. 523-529, 2006.

PIRANDA, E. M.; FACCINI, J. L. H.; PINTER, A.; PACHECO, P.; CANÇADO, P. H. D.; LABRUNA, M. B. Experimental Infection of Rhipicephalus sanguineus tick with the bacterium Rickettsia rickettsii use experimentally infected Dogs. Vector Borne and Zoonotic Diseases., v. 11, n.1, p. 29-36, 2011.

RAOULT, D.; ROUX, V. Rickettsioses as paradigms of new or emerging infectious diseases. Clin. Microbiol. Rev., v. 10, n. 4, p. 694-719, 1997.

REGNERY, R. L.; SPRUILL, C. L.; PLIKAYTIS, B. D. Genotypic identification of Rickettsiae and estimation of intraspecies sequence divergence for portions of two Rickettsial genes. J. Bacteriol., v. 173, p. 1576-1589, 1991.

RICKETTS, H. T. Some aspects of Rocky Mountain Spotted Fever as shown by recent investigations. Med. Rec., v. 76, p. 843-855, 1909.

ROUX, V.; RAOULT, D. Phylogenetic analysis of members of the genus Rickettsia using the gene encoding the outer-membrane protein rOmpB (OmpB). Internat. J. Syst. Evol. Microbiol., v. 50, p. 1449-1455, 2000.

ROUX, V.; RYDKINA, E.; EREMEEVA, M.; RAOULT, D. Citrate Synthase Gene Comparison, a New Tool for Phylogenetic analysis, and its application for the Rickettsiae. Intern. J. Syst. Bacteriol., v. 47, n. 2, p. 252-261, 1997.

ROZENTAL, T.; BUSTAMANTE, M. C.; AMORIM, M.; SERRA-FREIRE, N. M.; LEMOS, E.R. Evidence of spotted fever group rickettsiae in state of Rio de Janeiro, Brazil. Rev. Inst. Med. Trop. Sao Paulo, v. 44, n. 3, p. 155-158. 2002. 
ROZENTAL, T.; EREMEEVA, M. E; PADDOCK, C. D.; ZAKI, S. R.; DASCH, G. A.; LEMOS, E. R. S. Fatal case of Brazilian spotted fever confirmed by immunohistochemical staining and sequencing methods on fixed tissues. Ann. N. Y. Acad., 2006, v. 1078, p. $257-$ 259. [ $4^{\text {th }}$ International Conference on Rickettsiae and Rickettsial Diseases; 2005; Logroño].

SAMBROOK, J.; RUSSELL, D. W. Molecular Cloning: a laboratory manual. 3rd ed. New York: Cold Spring Harbor Laboratory Press, 2001.

SANGIONI, L. A. Pesquisa de infecção por riquétsias do grupo da Febre Maculosa em humanos, cães, eqüídeos e em adultos de Amblyomma cajennense, em região endêmica e não endêmica do estado de São Paulo. 2003. 86 f Doutorado (Tese em Medicina Veterinária) - Faculdade de Medicina Veterinária e Zootecnia, Universidade de São Paulo, São Paulo, 2003.

SERRA-FREIRE, N. M.; SENA, L. M. M.; BORSOI, A. B. P. Parasitismo Humano por Carrapatos na Mata Atlântica, Rio de Janeiro, Brasil. EntomoBrasilis, v. 4, n. 2, p. 67-72, 2011.

SEXTON, D. J.; MUNIZ, M.; COREY, G. R.; BREITSCHWERDT, E. B.; HEGARTY, B. C.; DUMLER, J. S. Brazilian spotted fever in Espírito Santo, Brazil: Description of a focus of infection in a new endemic region. Am. J. Med. Trop. Hyg., v. 49, p. 222-226, 1993.

SEXTON, D.J.; MUNIZ, M.; COREY, G.R.; BREITSCHWERDT, E.B.; HEGARTY, B.C.; DUMLER, J.S.; et al. Brazilian spotted fever in Espírito Santo, Brazil: Description of a focus of infection in a new endemic region Am. J. Med. Trop. Hyg., v. 49, p. 222-226, 1993.

SILVEIRA, I.; PACHECO, R. C.; SZABÓ, M. P.; RAMOS, H. G.; LABRUNA, M. B. Rickettsia parkeri in Brazil. Emerg. Infect. Dis., v.13, n.7, p.1111 - 1113, 2007.

SIMSER, J. A.; PALMER, A. T.; MUNDERLOH, U. G.; KURTTI, T. J. Isolation of a spotted fever group Rickettsia, Rickettsia peacockii, in a Rocky Mountain wood Tick, Dermacentor andersoni, cell line. Appl. Environ. Microbiol., v. 67, p. 546-552, 2001.

SOUZA, E. R.; GAZÊTA, G. S.; BARBOSA, P. R. A.; GONÇALVES, P. C.; NASCIMENTO, E. M.; SCHUMAKER, T. T. S. Detecção de riquétsias e erlíquias através de PCR em animais domésticos do Município de Valença / RJ. In: XIX Congresso Brasileiro de Parasitologia, 2005, Porto Alegre - RS, Brasil. Revista de Patologia Tropical, v. 34.

SOUZA, M. S. B. Aspectos epidemiológicos de potenciais vetores de riquétsias na região Metropolitana do estado do Rio de Janeiro. Monografia Especialização (Entomologia Médica) - Instituto Oswaldo Cruz, Fiocruz, Rio de Janeiro, 2009.

SPOLIDORIO, M. G. et al. Survey for tick-borne zoonoses in the state of Espirito Santo, southeastern Brazil. Am. J. Med. Trop. Hyg., v. 83, n. 1, p. 201-206, 2010.

STOTHARD, D. R.; CLARK, J. B.; FUERST, P. A. Ancestral divergence of Rickettsia bellii from the spotted fever and typhus groups of Rickettsia and antiquity of the genus Rickettsia. Int. J. Syst. Bacteriol., v. 44, n. 4, p. 798-804, 1994. 
SUCEN. Superintendência de Controle de Endemias-SP. Febre Maculosa: informações para profissionais da saúde. Acesso em 18 de janeiro 2013.

TAMURA, K.; PETERSON, D.; PETERSON, N.; STECHER, G.; NEI, M.; KUMAR, S. MEGA5: Molecular Evolutionary Genetics Analysis using maximum likelihood, evolutionary distance, and maximum parsimony methods. Molec. Biol. Evol., v. 28, n.10, p. 2731-2739. 2011.

VIANNA, M. C.; HORTA; M. C.; SANGIONI, L. A.; CORTEZ, A.; SOARES, R. M.; MAFRA, C. L.; GALVÃO, M. A.; LABRUNA, M. B.; GENNARI, S. M.; Rickettsial spotted fever in capoeirão village, Itabira, Minas Gerais, Brazil. Rev. Inst. Med. Trop. Sao Paulo. v. 50, n. 5, p. 297-301, 2008.

VITORINO, L.; CHELO, I. M.; BACELLAR, F.; ZE-ZE; L.; Rickettsiae phylogeny: a multigenic approach. Microbiology Sgm, n. 153, p. 160-168, 2007.

WEDINCAMP, J. JR; FOIL, L. D. Vertical transmission of Rickettsia felis in the cat flea (Ctenocephalides felis Bouché). J. Vector Ecol., v. 27, n.1, p. 96 - 101. 2002.

WIKSWO, M. E.; HU, R.; METZEGER, M. E.; EREMEEVA, M. E. Detection of Rickettsia rickettsii and Bartonela henselae in Rhipicephalus sanguineus from California. J. Med. Entomol., v. 44, p. 158-162, 2007. 
APÊEDICE A - Amostras de ectoparasitas coletados no munícipio de Petrópolis / Rio de Janeiro

Tabela 1 - Amostras de ectoparasitos coletados em Petrópolis/Rio de Janeiro

(continua)

\begin{tabular}{|c|c|c|c|c|c|c|c|c|}
\hline \multirow{2}{*}{ 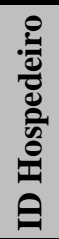 } & \multirow{2}{*}{\multicolumn{2}{|c|}{$\begin{array}{l}\text { Código no } \\
\text { eppendorf }\end{array}$}} & \multicolumn{3}{|c|}{ POOLS } & \multicolumn{3}{|c|}{ COLETA } \\
\hline & & & Espécie & 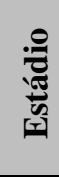 & $=\frac{\stackrel{\mathscr{E}}{\tilde{E}}}{\square}$ & Data & Local & Hospedeiro \\
\hline \multirow{13}{*}{$\begin{array}{l}\overrightarrow{0} \\
\frac{0}{\tilde{J}} \\
\text { त् }\end{array}$} & \multirow{13}{*}{1833} & A & Anocentor nitens & $\mathrm{F}$ & 1 & 03/11/2005 & $\begin{array}{l}\text { Itaipava-União } \\
\text { Industria } \\
\text { Itaipava-União }\end{array}$ & $\begin{array}{l}\text { Eqqus } \\
\text { caballus } \\
\text { Equus }\end{array}$ \\
\hline & & B & Anocentor nitens & $\mathrm{F}$ & 1 & $03 / 11 / 2005$ & Industria & caballus \\
\hline & & $\mathrm{C}$ & Anocentor nitens & $\mathrm{F}$ & 1 & $03 / 11 / 2005$ & $\begin{array}{l}\text { Itaipava-União } \\
\text { Industria }\end{array}$ & $\begin{array}{l}\text { Eqqus } \\
\text { caballus }\end{array}$ \\
\hline & & D & Anocentor nitens & $\mathrm{F}$ & 1 & 03/11/2005 & $\begin{array}{l}\text { Itaipava-Uniao } \\
\text { Industria }\end{array}$ & $\begin{array}{l}\text { Eqqus } \\
\text { caballus }\end{array}$ \\
\hline & & $\mathrm{E}$ & Anocentor nitens & $\mathrm{F}$ & 1 & 03/11/2005 & Industria & $\begin{array}{l}\text { Equas } \\
\text { caballus }\end{array}$ \\
\hline & & $\mathrm{F}$ & Anocentor nitens & $\mathrm{F}$ & 1 & $03 / 11 / 2005$ & $\begin{array}{l}\text { Itaipava-União } \\
\text { Industria }\end{array}$ & $\begin{array}{l}\text { Eqqus } \\
\text { caballus }\end{array}$ \\
\hline & & G & Anocentor nitens & $\mathrm{F}$ & 1 & $03 / 11 / 2005$ & $\begin{array}{l}\text { Itaipava-União } \\
\text { Industria }\end{array}$ & $\begin{array}{l}\text { Eqqus } \\
\text { caballus }\end{array}$ \\
\hline & & $\mathrm{H}$ & Anocentor nitens & $\mathrm{F}$ & 1 & $03 / 11 / 2005$ & $\begin{array}{l}\text { Itaipava-União } \\
\text { Industria } \\
\text { Itaipava-União }\end{array}$ & $\begin{array}{l}\text { Eqqus } \\
\text { caballus }\end{array}$ \\
\hline & & I & Anocentor nitens & $\mathrm{F}$ & 1 & $03 / 11 / 2005$ & Industria & caballus \\
\hline & & $\mathrm{J}$ & Anocentor nitens & $\mathrm{F}$ & 1 & 03/11/2005 & Industria & caballus \\
\hline & & $\mathrm{L}$ & Anocentor nitens & $\mathrm{F}$ & 1 & 03/11/2005 & $\begin{array}{l}\text { Itaipava-União } \\
\text { Industria }\end{array}$ & $\begin{array}{l}\text { Eqqus } \\
\text { caballus }\end{array}$ \\
\hline & & M & Anocentor nitens & M & 1 & $03 / 11 / 2005$ & $\begin{array}{l}\text { Itaipava-União } \\
\text { Industria }\end{array}$ & $\begin{array}{l}\text { Eqqus } \\
\text { caballus }\end{array}$ \\
\hline & & $\mathrm{N}$ & Amblyomma cajennense & $\mathrm{F}$ & 1 & $03 / 11 / 2005$ & $\begin{array}{l}\text { Itaipava-União } \\
\text { Industria }\end{array}$ & $\begin{array}{l}\text { Eqqus } \\
\text { caballus }\end{array}$ \\
\hline \multirow{3}{*}{$\begin{array}{l}\text { N } \\
0 \\
\frac{\pi}{\pi} \\
\text { స్ }\end{array}$} & \multirow{3}{*}{1837} & A & Amblyomma cajennense & M & 1 & $03 / 11 / 2005$ & $\begin{array}{l}\text { Itaipava-União } \\
\text { Industria }\end{array}$ & $\begin{array}{l}\text { Eqqus } \\
\text { caballus }\end{array}$ \\
\hline & & B & Amblyomma cajennense & $\mathrm{M}$ & 1 & $03 / 11 / 2005$ & & $\begin{array}{l}\text { Eqqus } \\
\text { caballus }\end{array}$ \\
\hline & & $\mathrm{C}$ & Amblyomma cajennense & M & 1 & $03 / 11 / 2005$ & $\begin{array}{l}\text { Itaipava-União } \\
\text { Industria }\end{array}$ & $\begin{array}{l}\text { Eqqus } \\
\text { caballus }\end{array}$ \\
\hline \multirow{2}{*}{$\begin{array}{l}\text { m } \\
\text { ० } \\
\text { त्य }\end{array}$} & \multirow{2}{*}{1838} & A & Amblyomma cajennense & M & 1 & $03 / 11 / 2005$ & $\begin{array}{l}\text { Itaipava-União } \\
\text { Industria }\end{array}$ & $\begin{array}{l}\text { Eqqus } \\
\text { caballus }\end{array}$ \\
\hline & & B & Amblyomma cajennense & M & 1 & $03 / 11 / 2005$ & $\begin{array}{l}\text { Itaipava-União } \\
\text { Industria }\end{array}$ & $\begin{array}{l}\text { Eqqus } \\
\text { caballus }\end{array}$ \\
\hline \multirow{5}{*}{$\overline{8}$} & \multirow{5}{*}{1839} & A & Boophilus microplus & M & 1 & $03 / 11 / 2005$ & $\begin{array}{l}\text { Itaipava -Faz. } \\
\text { Bela Vista } \\
\text { Itaipava -Faz. }\end{array}$ & Bos taurus \\
\hline & & B & Boophilus microplus & $\mathrm{F}$ & 1 & $03 / 11 / 2005$ & Bela Vista & Bos taurus \\
\hline & & $\mathrm{C}$ & Boophilus microplus & $\mathrm{F}$ & 1 & $03 / 11 / 2005$ & Bela Vista & Bos taurus \\
\hline & & D & Boophilus microplus & $\mathrm{F}$ & 1 & $03 / 11 / 2005$ & $\begin{array}{l}\text { Itapava -Faz. } \\
\text { Bela Vista }\end{array}$ & Bos taurus \\
\hline & & $\mathrm{E}$ & Boophilus microplus & $\mathrm{F}$ & 1 & $03 / 11 / 2005$ & $\begin{array}{c}\text { Itaipava -Faz. } \\
\text { Bela Vista }\end{array}$ & Bos taurus \\
\hline
\end{tabular}

M: machos; F: fêmeas; N: ninfas; Faz: Fazenda. 
Tabela 1 - Amostras de ectoparasitos coletados em Petrópolis/Rio de Janeiro

(continuação)

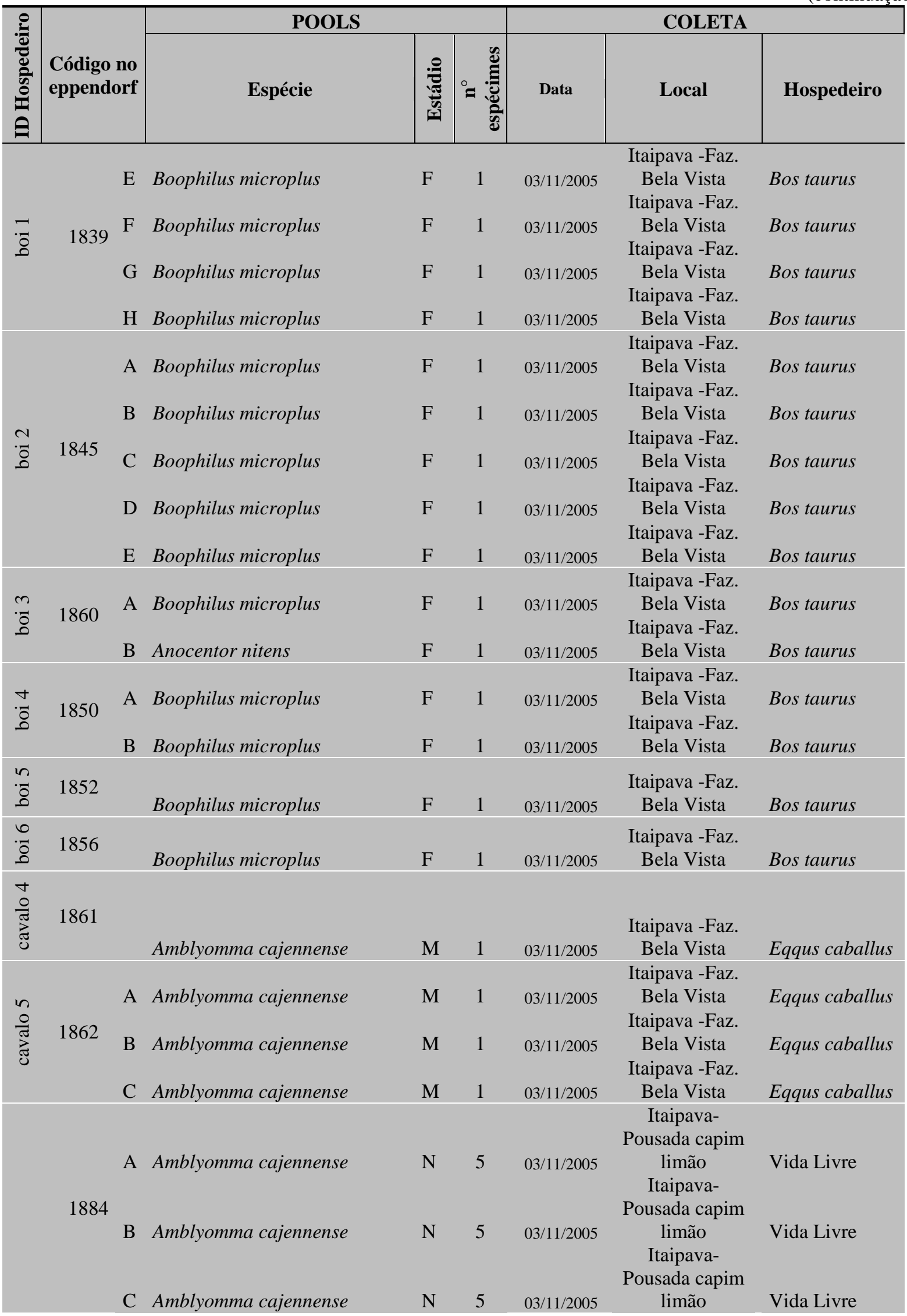

M: machos; F: fêmeas; N: ninfas; Faz: Fazenda. 
Tabela 1 - Amostras de ectoparasitos coletados em Petrópolis/Rio de Janeiro (continuação)

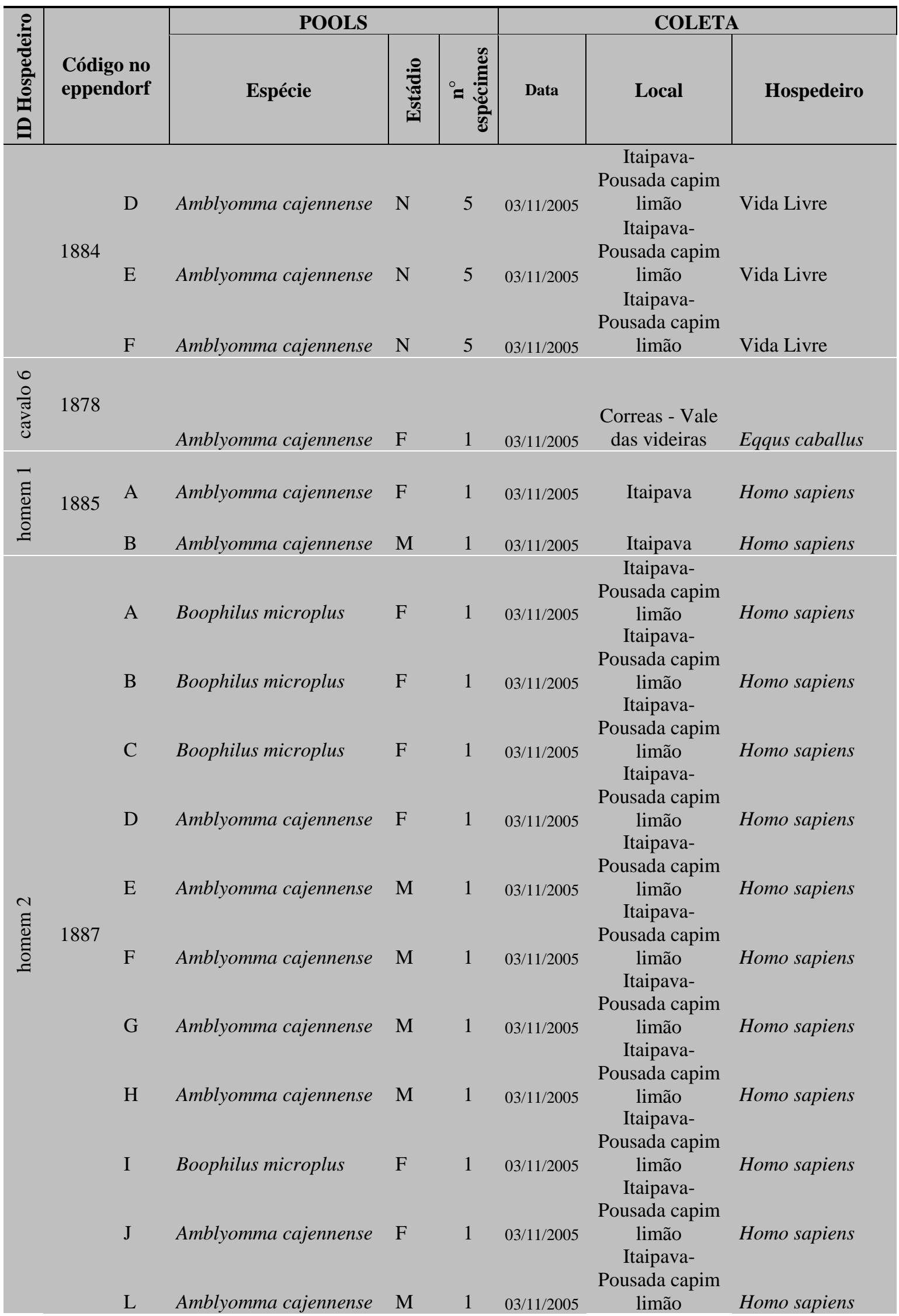

M: machos; F: fêmeas; N: ninfas; Faz: Fazenda 
Tabela 1 - Amostras de ectoparasitos coletados em Petrópolis/Rio de Janeiro

(continuação)

\begin{tabular}{|c|c|c|c|c|c|c|c|c|}
\hline \multirow{2}{*}{ 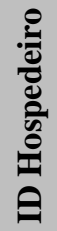 } & \multirow{2}{*}{\multicolumn{2}{|c|}{$\begin{array}{l}\text { Código no } \\
\text { eppendorf }\end{array}$}} & \multicolumn{3}{|l|}{ POOLS } & \multicolumn{3}{|c|}{ COLETA } \\
\hline & & & Espécie & $\frac{0}{3}$ & 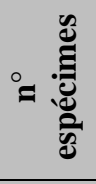 & Data & Local & Hospedeiro \\
\hline \multirow{23}{*}{$\begin{array}{l}\text { N } \\
\text { I్ָల }\end{array}$} & \multirow{23}{*}{1896} & A & Rhipicephalus sanguineus & $\mathrm{F}$ & 1 & $03 / 11 / 2005$ & $\begin{array}{c}\text { Itaipava- Vale } \\
\text { do Itajara }\end{array}$ & $\begin{array}{l}\text { Canis } \\
\text { familiaris }\end{array}$ \\
\hline & & B & Rhipicephalus sanguineus & $\mathrm{F}$ & 1 & $03 / 11 / 2005$ & $\begin{array}{c}\text { Itaipava- Vale } \\
\text { do Itajara }\end{array}$ & $\begin{array}{l}\text { Canis } \\
\text { familiaris }\end{array}$ \\
\hline & & $\mathrm{C}$ & Rhipicephalus sanguineus & $\mathrm{F}$ & 1 & $03 / 11 / 2005$ & $\begin{array}{c}\text { Itaipava- Vale } \\
\text { do Itajara }\end{array}$ & $\begin{array}{l}\text { Canis } \\
\text { familiaris }\end{array}$ \\
\hline & & $\mathrm{D}$ & Rhipicephalus sanguineus & $\mathrm{F}$ & 1 & $03 / 11 / 2005$ & $\begin{array}{c}\text { Itaipava- Vale } \\
\text { do Itajara }\end{array}$ & $\begin{array}{l}\text { Canis } \\
\text { familiaris }\end{array}$ \\
\hline & & $\mathrm{E}$ & Rhipicephalus sanguineus & $\mathrm{F}$ & 1 & $03 / 11 / 2005$ & $\begin{array}{c}\text { Itaipava- Vale } \\
\text { do Itajara }\end{array}$ & $\begin{array}{l}\text { Canis } \\
\text { familiaris }\end{array}$ \\
\hline & & $\mathrm{F}$ & Rhipicephalus sanguineus & $\mathrm{F}$ & 1 & $03 / 11 / 2005$ & $\begin{array}{c}\text { Itaipava- Vale } \\
\text { do Itajara }\end{array}$ & $\begin{array}{l}\text { Canis } \\
\text { familiaris }\end{array}$ \\
\hline & & G & Rhipicephalus sanguineus & $\mathrm{F}$ & 1 & $03 / 11 / 2005$ & $\begin{array}{c}\text { Itaipava- Vale } \\
\text { do Itajara }\end{array}$ & $\begin{array}{l}\text { Canis } \\
\text { familiaris }\end{array}$ \\
\hline & & $\mathrm{H}$ & Rhipicephalus sanguineus & $\mathrm{F}$ & 1 & $03 / 11 / 2005$ & $\begin{array}{c}\text { Itaipava- Vale } \\
\text { do Itajara }\end{array}$ & $\begin{array}{l}\text { Canis } \\
\text { familiaris }\end{array}$ \\
\hline & & I & Rhipicephalus sanguineus & $\mathrm{F}$ & 1 & $03 / 11 / 2005$ & $\begin{array}{c}\text { Itaipava- Vale } \\
\text { do Itajara }\end{array}$ & $\begin{array}{l}\text { Canis } \\
\text { familiaris }\end{array}$ \\
\hline & & $\mathrm{J}$ & Rhipicephalus sanguineus & $\mathrm{F}$ & 1 & $03 / 11 / 2005$ & $\begin{array}{c}\text { Itaipava- Vale } \\
\text { do Itajara }\end{array}$ & $\begin{array}{l}\text { Canis } \\
\text { familiaris }\end{array}$ \\
\hline & & $\mathrm{L}$ & Rhipicephalus sanguineus & $\mathrm{F}$ & 1 & $03 / 11 / 2005$ & $\begin{array}{c}\text { Itaipava- Vale } \\
\text { do Itajara }\end{array}$ & $\begin{array}{l}\text { Canis } \\
\text { familiaris }\end{array}$ \\
\hline & & M & Rhipicephalus sanguineus & $\mathrm{F}$ & 1 & $03 / 11 / 2005$ & $\begin{array}{l}\text { Itaipava- Vale } \\
\text { do Itajara }\end{array}$ & $\begin{array}{l}\text { Canis } \\
\text { familiaris }\end{array}$ \\
\hline & & $\mathrm{N}$ & Rhipicephalus sanguineus & $\mathrm{F}$ & 1 & $03 / 11 / 2005$ & $\begin{array}{c}\text { Itaipava- Vale } \\
\text { do Itajara }\end{array}$ & $\begin{array}{l}\text { Canis } \\
\text { familiaris }\end{array}$ \\
\hline & & $\mathrm{O}$ & Rhipicephalus sanguineus & $\mathrm{F}$ & 1 & $03 / 11 / 2005$ & $\begin{array}{l}\text { Itaipava- Vale } \\
\text { do Itajara }\end{array}$ & $\begin{array}{l}\text { Canis } \\
\text { familiaris }\end{array}$ \\
\hline & & $P$ & Rhipicephalus sanguineus & $\mathrm{F}$ & 1 & $03 / 11 / 2005$ & $\begin{array}{c}\text { Itaipava- Vale } \\
\text { do Itajara }\end{array}$ & $\begin{array}{l}\text { Canis } \\
\text { familiaris }\end{array}$ \\
\hline & & Q & Rhipicephalus sanguineus & $\mathrm{F}$ & 1 & $03 / 11 / 2005$ & $\begin{array}{c}\text { Itaipava- Vale } \\
\text { do Itajara }\end{array}$ & $\begin{array}{l}\text { Canis } \\
\text { familiaris }\end{array}$ \\
\hline & & $\mathrm{R}$ & Rhipicephalus sanguineus & $\mathrm{F}$ & 1 & $03 / 11 / 2005$ & $\begin{array}{c}\text { Itaipava- Vale } \\
\text { do Itajara }\end{array}$ & $\begin{array}{l}\text { Canis } \\
\text { familiaris }\end{array}$ \\
\hline & & $\mathrm{S}$ & Rhipicephalus sanguineus & $\mathrm{F}$ & 1 & $03 / 11 / 2005$ & $\begin{array}{c}\text { Itaipava- Vale } \\
\text { do Itajara }\end{array}$ & $\begin{array}{l}\text { Canis } \\
\text { familiaris }\end{array}$ \\
\hline & & $\mathrm{T}$ & Rhipicephalus sanguineus & $\mathrm{F}$ & 1 & $03 / 11 / 2005$ & $\begin{array}{c}\text { Itaipava- Vale } \\
\text { do Itajara }\end{array}$ & $\begin{array}{l}\text { Canis } \\
\text { familiaris }\end{array}$ \\
\hline & & $\mathrm{U}$ & Rhipicephalus sanguineus & $\mathrm{F}$ & 1 & $03 / 11 / 2005$ & $\begin{array}{c}\text { Itaipava- Vale } \\
\text { do Itajara }\end{array}$ & $\begin{array}{l}\text { Canis } \\
\text { familiaris }\end{array}$ \\
\hline & & $\mathrm{V}$ & Rhipicephalus sanguineus & $\mathrm{F}$ & 1 & $03 / 11 / 2005$ & $\begin{array}{c}\text { Itaipava- Vale } \\
\text { do Itajara }\end{array}$ & $\begin{array}{l}\text { Canis } \\
\text { familiaris }\end{array}$ \\
\hline & & $X$ & Rhipicephalus sanguineus & $\mathrm{F}$ & 1 & $03 / 11 / 2005$ & $\begin{array}{c}\text { Itaipava- Vale } \\
\text { do Itajara }\end{array}$ & $\begin{array}{l}\text { Canis } \\
\text { familiaris }\end{array}$ \\
\hline & & A1 & Rhipicephalus sanguineus & $\mathrm{F}$ & 1 & $03 / 11 / 2005$ & $\begin{array}{c}\text { Itaipava- Vale } \\
\text { do Itajara }\end{array}$ & $\begin{array}{l}\text { Canis } \\
\text { familiaris }\end{array}$ \\
\hline
\end{tabular}

M: machos; F: fêmeas; N: ninfas; Faz: Fazenda 
Tabela 1 - Amostras de ectoparasitos coletados em Petrópolis/Rio de Janeiro

(continuação)

\begin{tabular}{|c|c|c|c|c|c|c|c|c|}
\hline \multirow{2}{*}{ 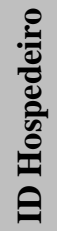 } & \multirow{2}{*}{\multicolumn{2}{|c|}{$\begin{array}{l}\text { Código no } \\
\text { eppendorf }\end{array}$}} & \multicolumn{3}{|l|}{ POOLS } & \multicolumn{3}{|c|}{ COLETA } \\
\hline & & & Espécie & 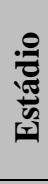 & 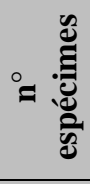 & Data & Local & Hospedeiro \\
\hline \multirow{23}{*}{$\begin{array}{l}\text { N } \\
\text { I్ָల }\end{array}$} & \multirow{23}{*}{1896} & B1 & Rhipicephalus sanguineus & $\mathrm{F}$ & 1 & $03 / 11 / 2005$ & $\begin{array}{c}\text { Itaipava- Vale } \\
\text { do Itajara }\end{array}$ & $\begin{array}{l}\text { Canis } \\
\text { familiaris }\end{array}$ \\
\hline & & $\mathrm{C} 1$ & Rhipicephalus sanguineus & $\mathrm{F}$ & 1 & $03 / 11 / 2005$ & $\begin{array}{c}\text { Itaipava- Vale } \\
\text { do Itajara }\end{array}$ & $\begin{array}{l}\text { Canis } \\
\text { familiaris }\end{array}$ \\
\hline & & D1 & Rhipicephalus sanguineus & $\mathrm{F}$ & 1 & $03 / 11 / 2005$ & $\begin{array}{c}\text { Itaipava- Vale } \\
\text { do Itajara }\end{array}$ & $\begin{array}{l}\text { Canis } \\
\text { familiaris }\end{array}$ \\
\hline & & E1 & Rhipicephalus sanguineus & $\mathrm{F}$ & 1 & $03 / 11 / 2005$ & $\begin{array}{c}\text { Itaipava- Vale } \\
\text { do Itajara }\end{array}$ & $\begin{array}{l}\text { Canis } \\
\text { familiaris }\end{array}$ \\
\hline & & F1 & Rhipicephalus sanguineus & $\mathrm{F}$ & 1 & $03 / 11 / 2005$ & $\begin{array}{c}\text { Itaipava- Vale } \\
\text { do Itajara }\end{array}$ & $\begin{array}{l}\text { Canis } \\
\text { familiaris }\end{array}$ \\
\hline & & G1 & Rhipicephalus sanguineus & $\mathrm{F}$ & 1 & $03 / 11 / 2005$ & $\begin{array}{c}\text { Itaipava- Vale } \\
\text { do Itajara }\end{array}$ & $\begin{array}{l}\text { Canis } \\
\text { familiaris }\end{array}$ \\
\hline & & H1 & Rhipicephalus sanguineus & $\mathrm{F}$ & 1 & $03 / 11 / 2005$ & $\begin{array}{c}\text { Itaipava- Vale } \\
\text { do Itajara }\end{array}$ & $\begin{array}{l}\text { Canis } \\
\text { familiaris }\end{array}$ \\
\hline & & I1 & Rhipicephalus sanguineus & $\mathrm{F}$ & 1 & $03 / 11 / 2005$ & $\begin{array}{c}\text { Itaipava- Vale } \\
\text { do Itajara }\end{array}$ & $\begin{array}{l}\text { Canis } \\
\text { familiaris }\end{array}$ \\
\hline & & $\mathrm{J} 1$ & Rhipicephalus sanguineus & $\mathrm{F}$ & 1 & $03 / 11 / 2005$ & $\begin{array}{c}\text { Itaipava- Vale } \\
\text { do Itajara }\end{array}$ & $\begin{array}{l}\text { Canis } \\
\text { familiaris }\end{array}$ \\
\hline & & L1 & Rhipicephalus sanguineus & $\mathrm{F}$ & 1 & $03 / 11 / 2005$ & $\begin{array}{c}\text { Itaipava- Vale } \\
\text { do Itajara }\end{array}$ & $\begin{array}{l}\text { Canis } \\
\text { familiaris }\end{array}$ \\
\hline & & M1 & Rhipicephalus sanguineus & $\mathrm{F}$ & 1 & $03 / 11 / 2005$ & $\begin{array}{c}\text { Itaipava- Vale } \\
\text { do Itajara }\end{array}$ & $\begin{array}{l}\text { Canis } \\
\text { familiaris }\end{array}$ \\
\hline & & N1 & Rhipicephalus sanguineus & $\mathrm{F}$ & 1 & $03 / 11 / 2005$ & $\begin{array}{l}\text { Itaipava- Vale } \\
\text { do Itajara }\end{array}$ & $\begin{array}{l}\text { Canis } \\
\text { familiaris }\end{array}$ \\
\hline & & $\mathrm{O} 1$ & Rhipicephalus sanguineus & $\mathrm{F}$ & 1 & $03 / 11 / 2005$ & $\begin{array}{c}\text { Itaipava- Vale } \\
\text { do Itajara }\end{array}$ & $\begin{array}{l}\text { Canis } \\
\text { familiaris }\end{array}$ \\
\hline & & $\mathrm{P} 1$ & Rhipicephalus sanguineus & $\mathrm{F}$ & 1 & $03 / 11 / 2005$ & $\begin{array}{c}\text { Itaipava- Vale } \\
\text { do Itajara }\end{array}$ & $\begin{array}{l}\text { Canis } \\
\text { familiaris }\end{array}$ \\
\hline & & Q1 & Rhipicephalus sanguineus & $\mathrm{F}$ & 1 & $03 / 11 / 2005$ & $\begin{array}{c}\text { Itaipava- Vale } \\
\text { do Itajara }\end{array}$ & $\begin{array}{l}\text { Canis } \\
\text { familiaris }\end{array}$ \\
\hline & & R1 & Rhipicephalus sanguineus & $\mathrm{F}$ & 1 & $03 / 11 / 2005$ & $\begin{array}{c}\text { Itaipava- Vale } \\
\text { do Itajara }\end{array}$ & $\begin{array}{l}\text { Canis } \\
\text { familiaris }\end{array}$ \\
\hline & & S1 & Rhipicephalus sanguineus & $\mathrm{F}$ & 1 & $03 / 11 / 2005$ & $\begin{array}{c}\text { Itaipava- Vale } \\
\text { do Itajara }\end{array}$ & $\begin{array}{l}\text { Canis } \\
\text { familiaris }\end{array}$ \\
\hline & & $\mathrm{T} 1$ & Rhipicephalus sanguineus & $\mathrm{F}$ & 1 & $03 / 11 / 2005$ & $\begin{array}{c}\text { Itaipava- Vale } \\
\text { do Itajara }\end{array}$ & $\begin{array}{l}\text { Canis } \\
\text { familiaris }\end{array}$ \\
\hline & & U1 & Rhipicephalus sanguineus & $\mathrm{F}$ & 1 & $03 / 11 / 2005$ & $\begin{array}{c}\text { Itaipava- Vale } \\
\text { do Itajara }\end{array}$ & $\begin{array}{l}\text { Canis } \\
\text { familiaris }\end{array}$ \\
\hline & & V1 & Rhipicephalus sanguineus & $\mathrm{F}$ & 1 & $03 / 11 / 2005$ & $\begin{array}{c}\text { Itaipava- Vale } \\
\text { do Itajara }\end{array}$ & $\begin{array}{l}\text { Canis } \\
\text { familiaris }\end{array}$ \\
\hline & & $\mathrm{X} 1$ & Rhipicephalus sanguineus & $\mathrm{F}$ & 1 & $03 / 11 / 2005$ & $\begin{array}{c}\text { Itaipava- Vale } \\
\text { do Itajara }\end{array}$ & $\begin{array}{l}\text { Canis } \\
\text { familiaris }\end{array}$ \\
\hline & & $\mathrm{Z} 1$ & Rhipicephalus sanguineus & $\mathrm{F}$ & 1 & $03 / 11 / 2005$ & $\begin{array}{c}\text { Itaipava- Vale } \\
\text { do Itajara }\end{array}$ & $\begin{array}{l}\text { Canis } \\
\text { familiaris }\end{array}$ \\
\hline & & W1 & Rhipicephalus sanguineus & $\mathrm{F}$ & 1 & $03 / 11 / 2005$ & $\begin{array}{c}\text { Itaipava- Vale } \\
\text { do Itajara }\end{array}$ & $\begin{array}{l}\text { Canis } \\
\text { familiaris }\end{array}$ \\
\hline
\end{tabular}

M: machos; F: fêmeas; N: ninfas; Faz: Fazenda 
Tabela 1 - Amostras de ectoparasitos coletados em Petrópolis/Rio de Janeiro

(continuação)

\begin{tabular}{|c|c|c|c|c|c|c|c|c|}
\hline \multirow{2}{*}{ 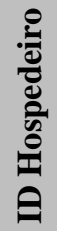 } & \multirow{2}{*}{\multicolumn{2}{|c|}{$\begin{array}{l}\text { Código no } \\
\text { eppendorf }\end{array}$}} & \multicolumn{3}{|l|}{ POOLS } & \multicolumn{3}{|c|}{ COLETA } \\
\hline & & & Espécie & 杀 & 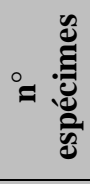 & Data & Local & Hospedeiro \\
\hline \multirow{23}{*}{$\begin{array}{l}\text { N } \\
\text { I్ָల }\end{array}$} & \multirow{23}{*}{1896} & Y1 & Rhipicephalus sanguineus & $\mathrm{F}$ & 1 & $03 / 11 / 2005$ & $\begin{array}{c}\text { Itaipava- Vale } \\
\text { do Itajara }\end{array}$ & $\begin{array}{l}\text { Canis } \\
\text { familiaris }\end{array}$ \\
\hline & & A2 & Rhipicephalus sanguineus & $\mathrm{F}$ & 1 & $03 / 11 / 2005$ & $\begin{array}{c}\text { Itaipava- Vale } \\
\text { do Itajara }\end{array}$ & $\begin{array}{l}\text { Canis } \\
\text { familiaris }\end{array}$ \\
\hline & & B2 & Rhipicephalus sanguineus & $\mathrm{F}$ & 1 & $03 / 11 / 2005$ & $\begin{array}{c}\text { Itaipava- Vale } \\
\text { do Itajara }\end{array}$ & $\begin{array}{l}\text { Canis } \\
\text { familiaris }\end{array}$ \\
\hline & & $\mathrm{C} 2$ & Rhipicephalus sanguineus & $\mathrm{F}$ & 1 & $03 / 11 / 2005$ & $\begin{array}{c}\text { Itaipava- Vale } \\
\text { do Itajara }\end{array}$ & $\begin{array}{l}\text { Canis } \\
\text { familiaris }\end{array}$ \\
\hline & & D2 & Rhipicephalus sanguineus & $\mathrm{F}$ & 1 & $03 / 11 / 2005$ & $\begin{array}{c}\text { Itaipava- Vale } \\
\text { do Itajara }\end{array}$ & $\begin{array}{l}\text { Canis } \\
\text { familiaris }\end{array}$ \\
\hline & & E2 & Rhipicephalus sanguineus & $\mathrm{F}$ & 1 & $03 / 11 / 2005$ & $\begin{array}{c}\text { Itaipava- Vale } \\
\text { do Itajara }\end{array}$ & $\begin{array}{l}\text { Canis } \\
\text { familiaris }\end{array}$ \\
\hline & & $\mathrm{F} 2$ & Rhipicephalus sanguineus & $\mathrm{F}$ & 1 & $03 / 11 / 2005$ & $\begin{array}{c}\text { Itaipava- Vale } \\
\text { do Itajara }\end{array}$ & $\begin{array}{l}\text { Canis } \\
\text { familiaris }\end{array}$ \\
\hline & & $\mathrm{G} 2$ & Rhipicephalus sanguineus & $\mathrm{F}$ & 1 & $03 / 11 / 2005$ & $\begin{array}{c}\text { Itaipava- Vale } \\
\text { do Itajara }\end{array}$ & $\begin{array}{l}\text { Canis } \\
\text { familiaris }\end{array}$ \\
\hline & & $\mathrm{H} 2$ & Rhipicephalus sanguineus & $\mathrm{F}$ & 1 & $03 / 11 / 2005$ & $\begin{array}{c}\text { Itaipava- Vale } \\
\text { do Itajara }\end{array}$ & $\begin{array}{l}\text { Canis } \\
\text { familiaris }\end{array}$ \\
\hline & & $\mathrm{I} 2$ & Rhipicephalus sanguineus & $\mathrm{F}$ & 1 & $03 / 11 / 2005$ & $\begin{array}{c}\text { Itaipava- Vale } \\
\text { do Itajara }\end{array}$ & $\begin{array}{l}\text { Canis } \\
\text { familiaris }\end{array}$ \\
\hline & & $\mathrm{J} 2$ & Rhipicephalus sanguineus & $\mathrm{F}$ & 1 & $03 / 11 / 2005$ & $\begin{array}{c}\text { Itaipava- Vale } \\
\text { do Itajara }\end{array}$ & $\begin{array}{l}\text { Canis } \\
\text { familiaris }\end{array}$ \\
\hline & & L2 & Rhipicephalus sanguineus & $\mathrm{F}$ & 1 & $03 / 11 / 2005$ & $\begin{array}{c}\text { Itaipava- Vale } \\
\text { do Itajara }\end{array}$ & $\begin{array}{l}\text { Canis } \\
\text { familiaris }\end{array}$ \\
\hline & & M2 & Rhipicephalus sanguineus & $\mathrm{F}$ & 1 & $03 / 11 / 2005$ & $\begin{array}{c}\text { Itaipava- Vale } \\
\text { do Itajara }\end{array}$ & $\begin{array}{l}\text { Canis } \\
\text { familiaris }\end{array}$ \\
\hline & & $\mathrm{N} 2$ & Rhipicephalus sanguineus & $\mathrm{F}$ & 1 & $03 / 11 / 2005$ & $\begin{array}{c}\text { Itaipava- Vale } \\
\text { do Itajara }\end{array}$ & $\begin{array}{l}\text { Canis } \\
\text { familiaris }\end{array}$ \\
\hline & & $\mathrm{O} 2$ & Rhipicephalus sanguineus & $\mathrm{F}$ & 1 & $03 / 11 / 2005$ & $\begin{array}{c}\text { Itaipava- Vale } \\
\text { do Itajara }\end{array}$ & $\begin{array}{l}\text { Canis } \\
\text { familiaris }\end{array}$ \\
\hline & & $\mathrm{P} 2$ & Rhipicephalus sanguineus & $\mathrm{F}$ & 1 & $03 / 11 / 2005$ & $\begin{array}{c}\text { Itaipava- Vale } \\
\text { do Itajara }\end{array}$ & $\begin{array}{l}\text { Canis } \\
\text { familiaris }\end{array}$ \\
\hline & & Q2 & Rhipicephalus sanguineus & $\mathrm{F}$ & 1 & $03 / 11 / 2005$ & $\begin{array}{c}\text { Itaipava- Vale } \\
\text { do Itajara }\end{array}$ & $\begin{array}{l}\text { Canis } \\
\text { familiaris }\end{array}$ \\
\hline & & $\mathrm{R} 2$ & Rhipicephalus sanguineus & $\mathrm{F}$ & 1 & $03 / 11 / 2005$ & $\begin{array}{c}\text { Itaipava- Vale } \\
\text { do Itajara }\end{array}$ & $\begin{array}{l}\text { Canis } \\
\text { familiaris }\end{array}$ \\
\hline & & $\mathrm{S} 2$ & Rhipicephalus sanguineus & $\mathrm{F}$ & 1 & $03 / 11 / 2005$ & $\begin{array}{c}\text { Itaipava- Vale } \\
\text { do Itajara }\end{array}$ & $\begin{array}{l}\text { Canis } \\
\text { familiaris }\end{array}$ \\
\hline & & $\mathrm{T} 2$ & Rhipicephalus sanguineus & $\mathrm{F}$ & 1 & $03 / 11 / 2005$ & $\begin{array}{c}\text { Itaipava- Vale } \\
\text { do Itajara }\end{array}$ & $\begin{array}{l}\text { Canis } \\
\text { familiaris }\end{array}$ \\
\hline & & $\mathrm{U} 2$ & Rhipicephalus sanguineus & $\mathrm{F}$ & 1 & $03 / 11 / 2005$ & $\begin{array}{c}\text { Itaipava- Vale } \\
\text { do Itajara }\end{array}$ & $\begin{array}{l}\text { Canis } \\
\text { familiaris }\end{array}$ \\
\hline & & $\mathrm{V} 2$ & Rhipicephalus sanguineus & $\mathrm{F}$ & 1 & $03 / 11 / 2005$ & $\begin{array}{c}\text { Itaipava- Vale } \\
\text { do Itajara }\end{array}$ & $\begin{array}{l}\text { Canis } \\
\text { familiaris }\end{array}$ \\
\hline & & $\mathrm{X} 2$ & Amblyomma cajennense & $\mathrm{N}$ & 1 & $03 / 11 / 2005$ & $\begin{array}{c}\text { Itaipava- Vale } \\
\text { do Itajara }\end{array}$ & $\begin{array}{l}\text { Canis } \\
\text { familiaris }\end{array}$ \\
\hline
\end{tabular}


Tabela 1 - Amostras de ectoparasitos coletados em Petrópolis/Rio de Janeiro

(continuação)

\begin{tabular}{|c|c|c|c|c|c|c|c|c|}
\hline \multirow{2}{*}{ 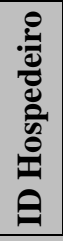 } & \multirow{2}{*}{\multicolumn{2}{|c|}{$\begin{array}{l}\text { Código no } \\
\text { eppendorf }\end{array}$}} & \multicolumn{3}{|l|}{ POOLS } & \multicolumn{3}{|c|}{ COLETA } \\
\hline & & & Espécie & 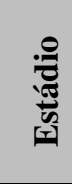 & 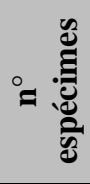 & Data & Local & Hospedeiro \\
\hline \multirow{23}{*}{$\begin{array}{l}\text { N } \\
\text { 1త్ర }\end{array}$} & \multirow{23}{*}{1896} & Y2 & Rhipicephalus sanguineus & M & 1 & $03 / 11 / 2005$ & $\begin{array}{c}\text { Itaipava- Vale } \\
\text { do Itajara }\end{array}$ & $\begin{array}{l}\text { Canis } \\
\text { familiaris }\end{array}$ \\
\hline & & W2 & Rhipicephalus sanguineus & M & 1 & $03 / 11 / 2005$ & $\begin{array}{c}\text { Itaipava- Vale } \\
\text { do Itajara }\end{array}$ & $\begin{array}{l}\text { Canis } \\
\text { familiaris }\end{array}$ \\
\hline & & $\mathrm{Z} 2$ & Amblyomma cajennense & M & 1 & $03 / 11 / 2005$ & $\begin{array}{c}\text { Itaipava- Vale } \\
\text { do Itajara }\end{array}$ & $\begin{array}{l}\text { Canis } \\
\text { familiaris }\end{array}$ \\
\hline & & A3 & Rhipicephalus sanguineus & M & 1 & $03 / 11 / 2005$ & $\begin{array}{c}\text { Itaipava- Vale } \\
\text { do Itajara }\end{array}$ & $\begin{array}{l}\text { Canis } \\
\text { familiaris }\end{array}$ \\
\hline & & B3 & Rhipicephalus sanguineus & M & 1 & $03 / 11 / 2005$ & $\begin{array}{c}\text { Itaipava- Vale } \\
\text { do Itajara }\end{array}$ & $\begin{array}{l}\text { Canis } \\
\text { familiaris }\end{array}$ \\
\hline & & C3 & Rhipicephalus sanguineus & M & 1 & $03 / 11 / 2005$ & $\begin{array}{c}\text { Itaipava- Vale } \\
\text { do Itajara }\end{array}$ & $\begin{array}{l}\text { Canis } \\
\text { familiaris }\end{array}$ \\
\hline & & D3 & Rhipicephalus sanguineus & M & 1 & $03 / 11 / 2005$ & $\begin{array}{c}\text { Itaipava- Vale } \\
\text { do Itajara }\end{array}$ & $\begin{array}{l}\text { Canis } \\
\text { familiaris }\end{array}$ \\
\hline & & E3 & Rhipicephalus sanguineus & M & 1 & $03 / 11 / 2005$ & $\begin{array}{c}\text { Itaipava- Vale } \\
\text { do Itajara }\end{array}$ & $\begin{array}{l}\text { Canis } \\
\text { familiaris }\end{array}$ \\
\hline & & $\mathrm{F} 3$ & Rhipicephalus sanguineus & M & 1 & $03 / 11 / 2005$ & $\begin{array}{c}\text { Itaipava- Vale } \\
\text { do Itajara }\end{array}$ & $\begin{array}{l}\text { Canis } \\
\text { familiaris }\end{array}$ \\
\hline & & G3 & Rhipicephalus sanguineus & M & 1 & $03 / 11 / 2005$ & $\begin{array}{c}\text { Itaipava- Vale } \\
\text { do Itajara }\end{array}$ & $\begin{array}{l}\text { Canis } \\
\text { familiaris }\end{array}$ \\
\hline & & H3 & Rhipicephalus sanguineus & M & 1 & $03 / 11 / 2005$ & $\begin{array}{c}\text { Itaipava- Vale } \\
\text { do Itajara }\end{array}$ & $\begin{array}{l}\text { Canis } \\
\text { familiaris }\end{array}$ \\
\hline & & I3 & Rhipicephalus sanguineus & M & 1 & $03 / 11 / 2005$ & $\begin{array}{c}\text { Itaipava- Vale } \\
\text { do Itajara }\end{array}$ & $\begin{array}{l}\text { Canis } \\
\text { familiaris }\end{array}$ \\
\hline & & $\mathrm{J} 3$ & Rhipicephalus sanguineus & M & 1 & $03 / 11 / 2005$ & $\begin{array}{c}\text { Itaipava- Vale } \\
\text { do Itajara }\end{array}$ & $\begin{array}{l}\text { Canis } \\
\text { familiaris }\end{array}$ \\
\hline & & L3 & Rhipicephalus sanguineus & M & 1 & $04 / 11 / 2005$ & $\begin{array}{c}\text { Itaipava- Vale } \\
\text { do Itajara }\end{array}$ & $\begin{array}{l}\text { Canis } \\
\text { familiaris }\end{array}$ \\
\hline & & M3 & Rhipicephalus sanguineus & M & 1 & $05 / 11 / 2005$ & $\begin{array}{c}\text { Itaipava- Vale } \\
\text { do Itajara }\end{array}$ & $\begin{array}{l}\text { Canis } \\
\text { familiaris }\end{array}$ \\
\hline & & N3 & Rhipicephalus sanguineus & M & 1 & $06 / 11 / 2005$ & $\begin{array}{c}\text { Itaipava- Vale } \\
\text { do Itajara }\end{array}$ & $\begin{array}{l}\text { Canis } \\
\text { familiaris }\end{array}$ \\
\hline & & $\mathrm{O} 3$ & Rhipicephalus sanguineus & M & 1 & $07 / 11 / 2005$ & $\begin{array}{c}\text { Itaipava- Vale } \\
\text { do Itajara }\end{array}$ & $\begin{array}{l}\text { Canis } \\
\text { familiaris }\end{array}$ \\
\hline & & P3 & Rhipicephalus sanguineus & M & 1 & $08 / 11 / 2005$ & $\begin{array}{c}\text { Itaipava- Vale } \\
\text { do Itajara }\end{array}$ & $\begin{array}{l}\text { Canis } \\
\text { familiaris }\end{array}$ \\
\hline & & Q3 & Rhipicephalus sanguineus & M & 1 & $09 / 11 / 2005$ & $\begin{array}{c}\text { Itaipava- Vale } \\
\text { do Itajara }\end{array}$ & $\begin{array}{l}\text { Canis } \\
\text { familiaris }\end{array}$ \\
\hline & & $\mathrm{R} 3$ & Rhipicephalus sanguineus & M & 1 & $10 / 11 / 2005$ & $\begin{array}{c}\text { Itaipava- Vale } \\
\text { do Itajara }\end{array}$ & $\begin{array}{l}\text { Canis } \\
\text { familiaris }\end{array}$ \\
\hline & & S3 & Rhipicephalus sanguineus & M & 1 & $11 / 11 / 2005$ & $\begin{array}{c}\text { Itaipava- Vale } \\
\text { do Itajara }\end{array}$ & $\begin{array}{l}\text { Canis } \\
\text { familiaris }\end{array}$ \\
\hline & & $\mathrm{T} 3$ & Rhipicephalus sanguineus & M & 1 & $12 / 11 / 2005$ & $\begin{array}{c}\text { Itaipava- Vale } \\
\text { do Itajara }\end{array}$ & $\begin{array}{l}\text { Canis } \\
\text { familiaris }\end{array}$ \\
\hline & & U3 & Rhipicephalus sanguineus & M & 1 & $13 / 11 / 2005$ & $\begin{array}{c}\text { Itaipava- Vale } \\
\text { do Itajara }\end{array}$ & $\begin{array}{l}\text { Canis } \\
\text { familiaris }\end{array}$ \\
\hline
\end{tabular}

M: machos; F: fêmeas; N: ninfas; Faz: Fazenda 
Tabela 1 - Amostras de ectoparasitos coletados em Petrópolis/Rio de Janeiro

(continuação)

\begin{tabular}{|c|c|c|c|c|c|c|c|c|}
\hline \multirow{2}{*}{ 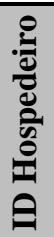 } & \multirow{2}{*}{\multicolumn{2}{|c|}{$\begin{array}{l}\text { Código no } \\
\text { eppendorf }\end{array}$}} & \multicolumn{3}{|l|}{ POOLS } & \multicolumn{3}{|c|}{ COLETA } \\
\hline & & & Espécie & 杀 & 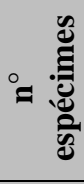 & Data & Local & Hospedeiro \\
\hline \multirow{5}{*}{$\begin{array}{l}\text { N } \\
\text { Iత్ర }\end{array}$} & \multirow{5}{*}{1896} & V3 & Rhipicephalus sanguineus & M & 1 & $14 / 11 / 2005$ & $\begin{array}{c}\text { Itaipava- Vale } \\
\text { do Itajara }\end{array}$ & Canis familiaris \\
\hline & & $\mathrm{X} 3$ & Rhipicephalus sanguineus & M & 1 & $15 / 11 / 2005$ & $\begin{array}{c}\text { Itaipava- Vale } \\
\text { do Itajara }\end{array}$ & Canis familiaris \\
\hline & & $\mathrm{Z3}$ & Rhipicephalus sanguineus & M & 1 & $16 / 11 / 2005$ & $\begin{array}{l}\text { Itaipava- Vale } \\
\text { do Itajara }\end{array}$ & Canis familiaris \\
\hline & & W3 & Rhipicephalus sanguineus & M & 1 & $17 / 11 / 2005$ & $\begin{array}{l}\text { Itaipava- Vale } \\
\text { do Itajara }\end{array}$ & Canis familiaris \\
\hline & & Y3 & Rhipicephalus sanguineus & M & 1 & $18 / 11 / 2005$ & $\begin{array}{c}\text { Itaipava- Vale } \\
\text { do Itajara }\end{array}$ & Canis familiaris \\
\hline \multirow{3}{*}{$\overline{0}$} & \multirow{3}{*}{1901} & A & Rhipicephalus sanguineus & $\mathrm{F}$ & 1 & $30 / 05 / 2005$ & Mozela & Bos Taurus \\
\hline & & $\mathrm{B}$ & Rhipicephalus sanguineus & $\mathrm{F}$ & 1 & $30 / 05 / 2005$ & Mozela & Bos Taurus \\
\hline & & $\mathrm{C}$ & Rhipicephalus sanguineus & $\mathrm{F}$ & 1 & $30 / 05 / 2005$ & Mozela & Bos Taurus \\
\hline \multirow{3}{*}{$\begin{array}{l}\hat{0} \\
\frac{0}{\pi} \\
\text { తิ }\end{array}$} & \multirow{3}{*}{1906} & A & Amblyomma cajennense & $\mathrm{F}$ & 1 & $11 / 11 / 2005$ & Itaipava & Equus cabalus \\
\hline & & B & Amblyomma cajennense & M & 1 & $11 / 11 / 2005$ & Itaipava & Equus cabalus \\
\hline & & $\mathrm{C}$ & Amblyomma cajennense & M & 1 & $11 / 11 / 2005$ & Itaipava & Equus cabalus \\
\hline \multirow{12}{*}{$\begin{array}{l}\infty \\
\frac{0}{\pi} \\
\stackrel{\overbrace{}}{\pi}\end{array}$} & \multirow{9}{*}{1907} & A & Amblyomma cajennense & $\mathrm{F}$ & 1 & $11 / 11 / 2005$ & Itaipava & Equus cabalus \\
\hline & & $\mathrm{B}$ & Amblyomma cajennense & M & 1 & $11 / 11 / 2005$ & Itaipava & Equus cabalus \\
\hline & & $\mathrm{C}$ & Amblyomma cajennense & M & 1 & $11 / 11 / 2005$ & Itaipava & Equus cabalus \\
\hline & & $\mathrm{D}$ & Amblyomma cajennense & M & 1 & $11 / 11 / 2005$ & Itaipava & Equus cabalus \\
\hline & & $\mathrm{E}$ & Amblyomma cajennense & $\mathrm{F}$ & 1 & $11 / 11 / 2005$ & Itaipava & Equus cabalus \\
\hline & & $\mathrm{F}$ & Amblyomma cajennense & $\mathrm{F}$ & 1 & $11 / 11 / 2005$ & Itaipava & Equus cabalus \\
\hline & & $\mathrm{G}$ & Amblyomma cajennense & M & 1 & $11 / 11 / 2005$ & Itaipava & Equus cabalus \\
\hline & & $\mathrm{H}$ & Amblyomma cajennense & M & 1 & $11 / 11 / 2005$ & Itaipava & Equus cabalus \\
\hline & & I & Amblyomma cajennense & M & 1 & $11 / 11 / 2005$ & Itaipava & Equus cabalus \\
\hline & \multirow{3}{*}{ 1907II } & A & Amblyomma cajennense & M & 1 & $11 / 11 / 2005$ & Itaipava & Equus cabalus \\
\hline & & B & Amblyomma cajennense & M & 1 & $11 / 11 / 2005$ & Itaipava & Equus cabalus \\
\hline & & $\mathrm{C}$ & Amblyomma cajennense & M & 1 & $11 / 11 / 2005$ & Itaipava & Equus cabalus \\
\hline
\end{tabular}

M: machos; F: fêmeas; N: ninfas; Faz: Fazenda. 
Tabela 1 - Amostras de ectoparasitos coletados em Petrópolis/Rio de Janeiro

(continuação)

\begin{tabular}{|c|c|c|c|c|c|c|c|c|}
\hline \multirow{2}{*}{ 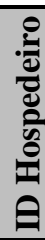 } & \multirow{2}{*}{\multicolumn{2}{|c|}{$\begin{array}{l}\text { Código no } \\
\text { eppendorf }\end{array}$}} & \multicolumn{3}{|l|}{ POOLS } & \multicolumn{3}{|c|}{ COLETA } \\
\hline & & & Espécie & 赵 & 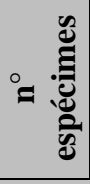 & Data & Local & Hospedeiro \\
\hline \multirow{9}{*}{$\begin{array}{l}\infty \\
0 \\
\frac{0}{\pi} \\
\text { స్ }\end{array}$} & \multirow{9}{*}{1907 II } & $\mathrm{D}$ & Anocentor nitens & $\mathrm{F}$ & 1 & $11 / 11 / 2005$ & Itaipava & Equus cabalus \\
\hline & & $\mathrm{E}$ & Anocentor nitens & $\mathrm{F}$ & 1 & $11 / 11 / 2005$ & Itaipava & Equus cabalus \\
\hline & & $\mathrm{F}$ & Anocentor nitens & $\mathrm{F}$ & 1 & $11 / 11 / 2005$ & Itaipava & Equus cabalus \\
\hline & & $\mathrm{G}$ & Anocentor nitens & F & 1 & $11 / 11 / 2005$ & Itaipava & Equus cabalus \\
\hline & & $\mathrm{H}$ & Anocentor nitens & $\mathrm{F}$ & 1 & $11 / 11 / 2005$ & Itaipava & Equus cabalus \\
\hline & & $\mathrm{J}$ & Anocentor nitens & $\mathrm{F}$ & 1 & $11 / 11 / 2005$ & Itaipava & Equus cabalus \\
\hline & & $\mathrm{L}$ & Anocentor nitens & $\mathrm{F}$ & 1 & $11 / 11 / 2005$ & Itaipava & Equus cabalus \\
\hline & & M & Anocentor nitens & $\mathrm{F}$ & 1 & $11 / 11 / 2005$ & Itaipava & Equus cabalus \\
\hline & & $\mathrm{N}$ & Anocentor nitens & $\mathrm{F}$ & 1 & $11 / 11 / 2005$ & Itaipava & Equus cabalus \\
\hline \multirow{13}{*}{$\begin{array}{l}\hat{a} \\
\frac{0}{\pi} \\
\text { స్ }\end{array}$} & \multirow{13}{*}{1909} & A & Rhipicephalus sanguineus & $\mathrm{F}$ & 1 & $11 / 11 / 2005$ & Itaipava & Equus cabalus \\
\hline & & $\mathrm{B}$ & Anocentor nitens & $\mathrm{F}$ & 1 & $11 / 11 / 2005$ & Itaipava & Equus cabalus \\
\hline & & $\mathrm{C}$ & Anocentor nitens & $\mathrm{N}$ & 1 & $11 / 11 / 2005$ & Itaipava & Equus cabalus \\
\hline & & $\mathrm{D}$ & Anocentor nitens & $\mathrm{N}$ & 1 & $11 / 11 / 2005$ & Itaipava & Equus cabalus \\
\hline & & $\mathrm{E}$ & Anocentor nitens & $\mathrm{N}$ & 1 & $11 / 11 / 2005$ & Itaipava & Equus cabalus \\
\hline & & $\mathrm{F}$ & Anocentor nitens & $\mathrm{N}$ & 1 & $11 / 11 / 2005$ & Itaipava & Equus cabalus \\
\hline & & $\mathrm{G}$ & Rhipicephalus sanguineus & M & 1 & $11 / 11 / 2005$ & Itaipava & Equus cabalus \\
\hline & & $\mathrm{H}$ & Rhipicephalus sanguineus & M & 1 & $11 / 11 / 2005$ & Itaipava & Equus cabalus \\
\hline & & I & Amblyomma cajennense & M & 1 & $11 / 11 / 2005$ & Itaipava & Equus cabalus \\
\hline & & $\mathrm{J}$ & Amblyomma cajennense & M & 1 & $11 / 11 / 2005$ & Itaipava & Equus cabalus \\
\hline & & $\mathrm{L}$ & Amblyomma cajennense & M & 1 & $11 / 11 / 2005$ & Itaipava & Equus cabalus \\
\hline & & M & Amblyomma cajennense & M & 1 & $11 / 11 / 2005$ & Itaipava & Equus cabalus \\
\hline & & $\mathrm{N}$ & Amblyomma cajennense & M & 1 & $11 / 11 / 2005$ & Itaipava & Equus cabalus \\
\hline \multirow{3}{*}{$\begin{array}{l}\frac{0}{0} \\
\frac{0}{\pi} \\
\frac{\pi}{0}\end{array}$} & \multirow{3}{*}{1908} & A & Amblyomma cajennense & M & 1 & $11 / 11 / 2005$ & Itaipava & Equus cabalus \\
\hline & & $\mathrm{B}$ & Anocentor nitens & $\mathrm{N}$ & 1 & $11 / 11 / 2005$ & Itaipava & Equus cabalus \\
\hline & & $\mathrm{C}$ & Amblyomma cajennense & M & 1 & $11 / 11 / 2005$ & Itaipava & Equus cabalus \\
\hline
\end{tabular}

M: machos; F: fêmeas; N: ninfas; Faz: Fazenda 
Tabela 1 - Amostras de ectoparasitos coletados em Petrópolis/Rio de Janeiro

(continuação)

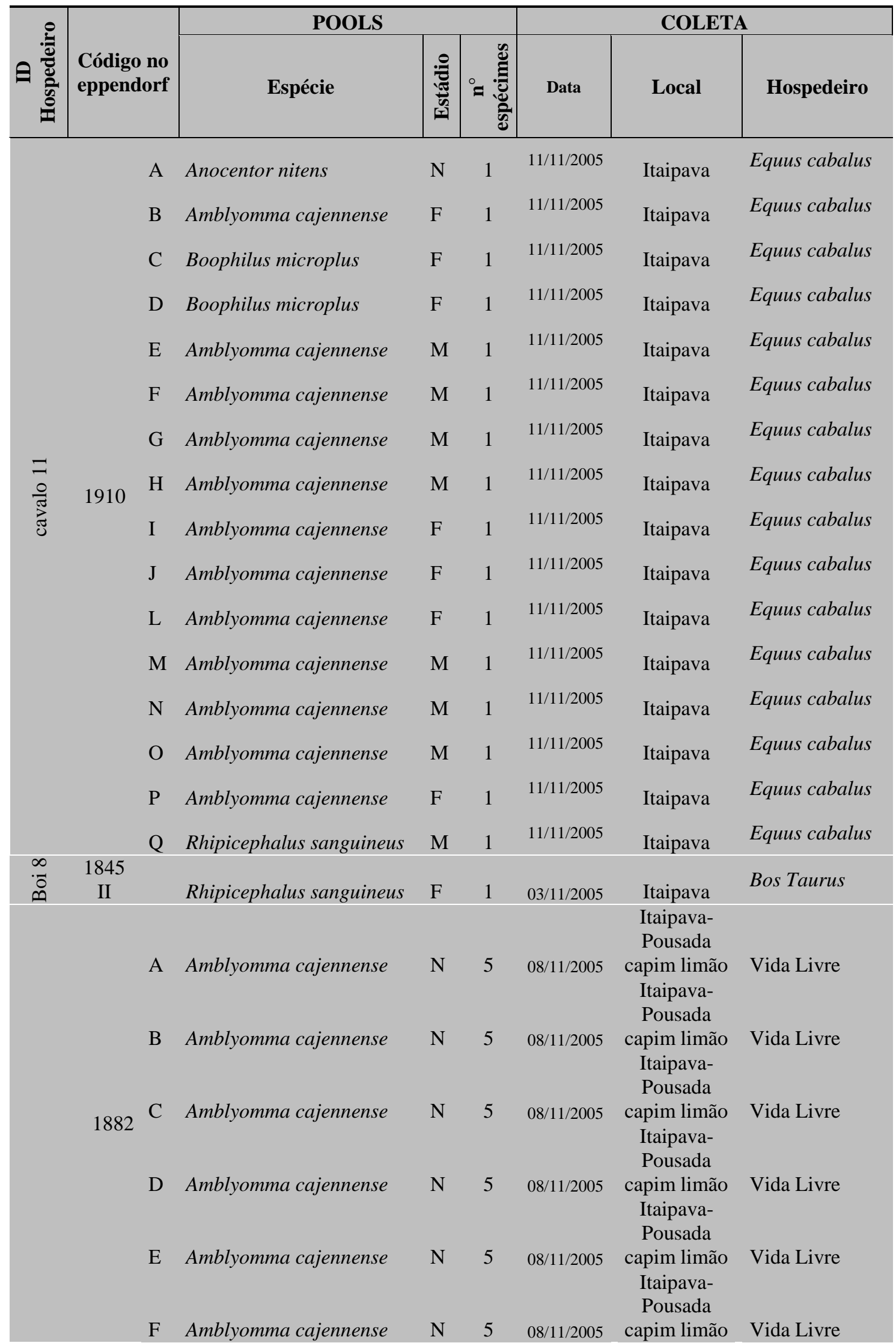

M: machos; F: fêmeas; N: ninfas; Faz: Fazenda 
Tabela 1 - Amostras de ectoparasitos coletados em Petrópolis/Rio de Janeiro

(continuação)

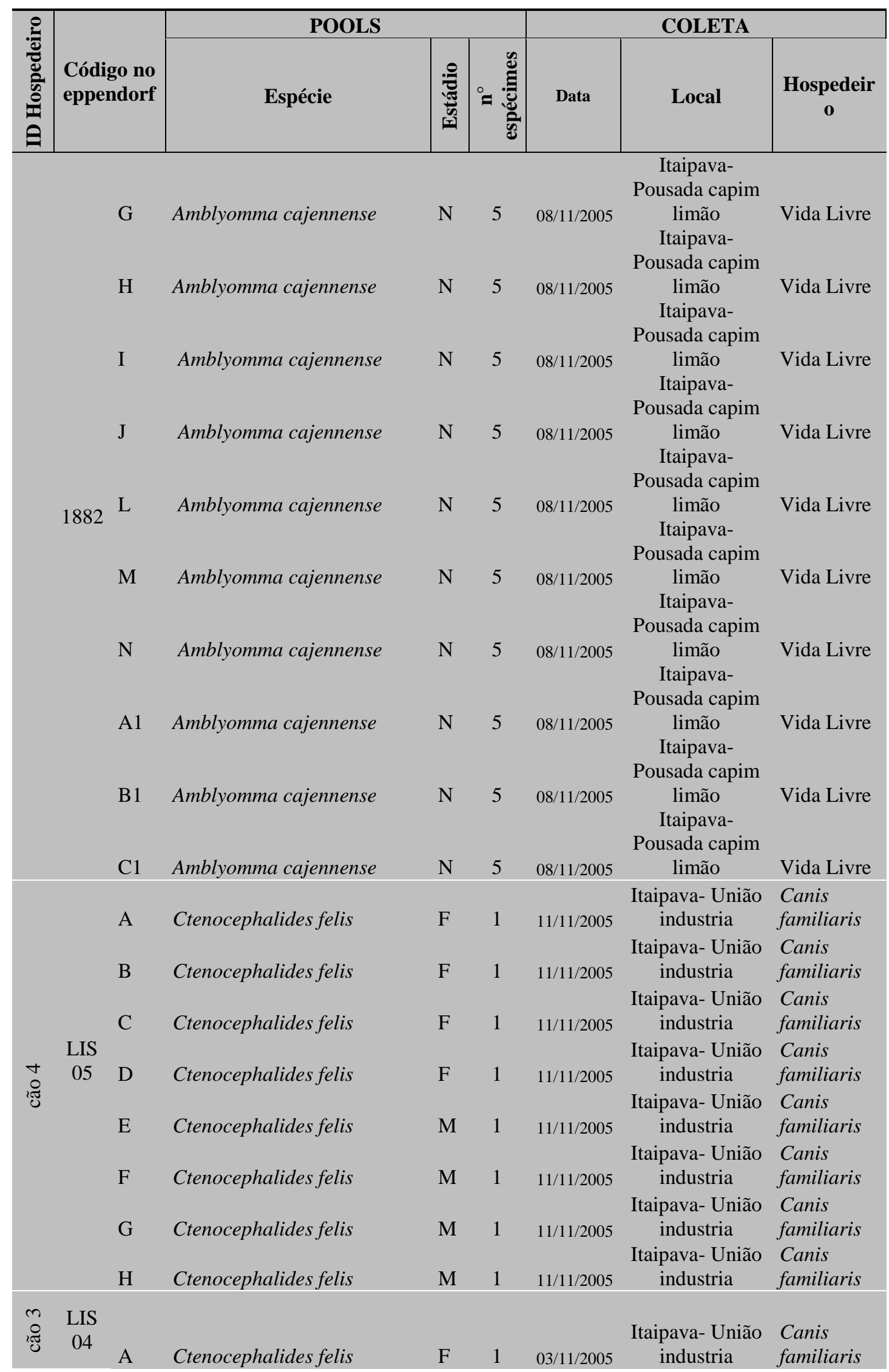

M: machos; F: fêmeas; N: ninfas; Faz: Fazenda. 
Tabela 1 - Amostras de ectoparasitos coletados em Petrópolis/Rio de Janeiro

(conclusão)

\begin{tabular}{|c|c|c|c|c|c|c|c|c|}
\hline \multirow{2}{*}{ 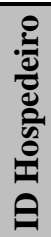 } & \multirow{2}{*}{\multicolumn{2}{|c|}{$\begin{array}{l}\text { Código no } \\
\text { eppendorf }\end{array}$}} & \multicolumn{3}{|c|}{ POOLS } & \multicolumn{3}{|c|}{ COLETA } \\
\hline & & & Espécie & 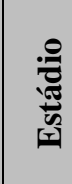 & 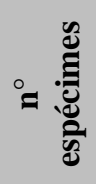 & Data & Local & Hospedeiro \\
\hline \multirow{6}{*}{ ఇָ } & \multirow{6}{*}{$\begin{array}{l}\text { LIS } \\
04\end{array}$} & B & Ctenocephalides felis & $\mathrm{F}$ & 1 & $03 / 11 / 2005$ & $\begin{array}{l}\text { Itaipava- União } \\
\text { industria }\end{array}$ & $\begin{array}{l}\text { Canis } \\
\text { familiaris }\end{array}$ \\
\hline & & $\mathrm{C}$ & Ctenocephalides felis & $\mathrm{F}$ & 1 & $03 / 11 / 2005$ & $\begin{array}{l}\text { Itaipava- União } \\
\text { industria }\end{array}$ & $\begin{array}{l}\text { Canis } \\
\text { familiaris }\end{array}$ \\
\hline & & $\mathrm{D}$ & Ctenocephalides felis & M & 2 & $03 / 11 / 2005$ & $\begin{array}{l}\text { Itaipava- União } \\
\text { industria }\end{array}$ & $\begin{array}{l}\text { Canis } \\
\text { familiaris }\end{array}$ \\
\hline & & $\mathrm{E}$ & Ctenocephalides felis & M & 2 & $03 / 11 / 2005$ & $\begin{array}{l}\text { Itaipava- União } \\
\text { industria }\end{array}$ & $\begin{array}{l}\text { Canis } \\
\text { familiaris }\end{array}$ \\
\hline & & $\mathrm{F}$ & Ctenocephalides felis & M & 2 & $03 / 11 / 2005$ & $\begin{array}{c}\text { Itaipava- União } \\
\text { industria }\end{array}$ & $\begin{array}{l}\text { Canis } \\
\text { familiaris }\end{array}$ \\
\hline & & $\mathrm{G}$ & Ctenocephalides felis & M & 2 & $03 / 11 / 2005$ & $\begin{array}{l}\text { Itaipava- União } \\
\text { industria }\end{array}$ & $\begin{array}{l}\text { Canis } \\
\text { familiaris }\end{array}$ \\
\hline \multirow{2}{*}{ ?ీ } & \multirow{2}{*}{$\begin{array}{c}\text { LIS } \\
03\end{array}$} & A & Ctenocephalides felis & $\mathrm{F}$ & 1 & $03 / 11 / 2005$ & $\begin{array}{l}\text { Itaipava- União } \\
\text { industria }\end{array}$ & $\begin{array}{l}\text { Canis } \\
\text { familiaris }\end{array}$ \\
\hline & & B & Ctenocephalides felis & M & 2 & $03 / 11 / 2005$ & $\begin{array}{l}\text { Itaipava- União } \\
\text { industria }\end{array}$ & $\begin{array}{l}\text { Canis } \\
\text { familiaris }\end{array}$ \\
\hline \multirow{4}{*}{$\stackrel{0}{\overparen{0}}$} & \multirow{4}{*}{$\begin{array}{c}\text { LIS } \\
02\end{array}$} & A & Ctenocephalides felis & $\mathrm{F}$ & 1 & $03 / 11 / 2005$ & $\begin{array}{l}\text { Itaipava- União } \\
\text { industria }\end{array}$ & Felis catus \\
\hline & & B & Ctenocephalides felis & $\mathrm{F}$ & 1 & $03 / 11 / 2005$ & $\begin{array}{l}\text { Itaipava- União } \\
\text { industria }\end{array}$ & Felis catus \\
\hline & & $\mathrm{C}$ & Ctenocephalides felis & $\mathrm{F}$ & 1 & $03 / 11 / 2005$ & $\begin{array}{l}\text { Itaipava- União } \\
\text { industria }\end{array}$ & Felis catus \\
\hline & & $\mathrm{D}$ & Ctenocephalides felis & M & 1 & $03 / 11 / 2005$ & $\begin{array}{l}\text { Itaipava- União } \\
\text { industria }\end{array}$ & Felis catus \\
\hline 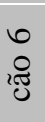 & $\begin{array}{l}\text { LIS } \\
273\end{array}$ & 4 & Ctenocephalides felis & $\mathrm{F}$ & 1 & $16 / 09 / 2010$ & $\begin{array}{c}\text { Carangola - } \\
\text { Rua Servidão } \\
\text { das Bromelias }\end{array}$ & $\begin{array}{l}\text { Canis } \\
\text { familiaris }\end{array}$ \\
\hline
\end{tabular}

M: machos; F: fêmeas; N: ninfas; Faz: Fazenda. 
APÊNDICE B - Alinhamento de sequências de Rickettsia rickettsii e iniciador VNTRB
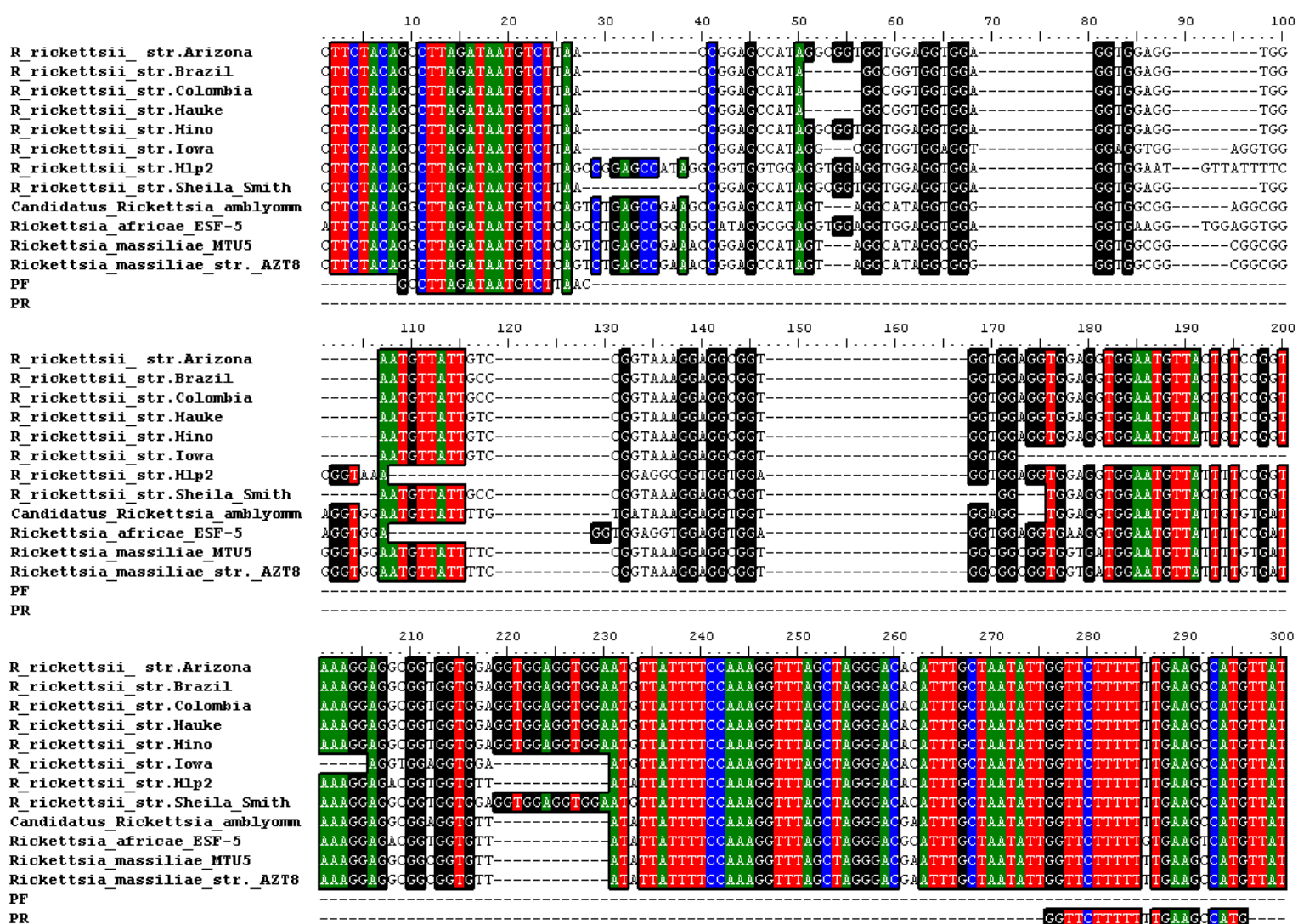